\title{
THE ASSEMBLAGE OF POWER: THE ROLE OF THE STATE IN MINIMUM WAGE POLICY IN INDONESIA
}

\author{
By \\ WAHYU ADININGTYAS
}

\begin{abstract}
A thesis
submitted to the Victoria University of Wellington in fulfilment of the requirements for the degree of Master of Arts in Sociology
\end{abstract}

Victoria University of Wellington 2018 


\section{Acknowledgements}

I would first like to thank the participants who offered their time during the data collection phase of the research. Their names cannot be disclosed here. But I want to acknowledge my appreciation of their willingness to be interviewed. Hopefully, this thesis will be useful for all of us.

I would like to express my deepest appreciation to Dr Chamsy el-Ojeili and Dr Dylan Taylor, who gave me the opportunity to work on this topic; for the precious time, energy and knowledge they contributed while I worked on this thesis. For any faults in the final thesis, I take full responsibility.

I am so grateful to the New Zealand ASEAN Scholarship that gave me the opportunity to study in New Zealand.

I also thank all of my friends who supported me and transferred their positive energy to me; both in New Zealand and in Indonesia.

I could not forget to thank my mother and my father. Your toughness in life has always inspired me. Thanks also to my brothers and sisters who have always supported me in my choices.

Thanks to my beloved husband, George Hormat, who was willing to listen to all the dilemmas I faced during this thesis. Thank you for assisting me with data collection and for problem solving alongside me.

Finally, thank you to my son, Jyestha, who, with tremendous patience, accompanied me to New Zealand. I have learned true patience from you. 


\begin{abstract}
The minimum wage is an essential issue for workers in Indonesia. Employers still apply the minimum wage to all workers, regardless of their experience. Further, the calculation of the minimum wage is still based on an estimate for single workers. This calculation can mean that a worker is unable to meet the daily needs of their dependent family. Workers in Indonesia are trapped in debt and poverty. The minimum wage in Indonesia is intended as a safety net to prevent workers from falling into poverty, with workers' welfare the responsibility of the state.

This study aims to examine the role of the state in determining the minimum wage policy. The outcomes of this process cannot be separated from the strength of workers and employers to communicate their interests. As a semi-peripheral country within the international division of labour, the minimum wage policy in Indonesia is influenced by the interests of international capital.

This qualitative study uses the capitalist state theories of Miliband, Poulantzas and Jessop to examine the role of the state and worker-employer relations, and the influence of the international market on determining minimum wage policy in Indonesia -with world-systems analysis also drawn on to investigate the international market context.

Overall, this study proves that wage rates are the result of the struggle of agency, i.e. workers, employers and government personnel through various institutions, regulatory products and laws. The various regulations and institutions of the state ensure that the struggle between these interest groups takes place in a way that does not endanger capitalism as the prevailing economic and political system. For workers, the struggle for increased wages occurs at two levels. Firstly through tripartite institutions -Institutions where workers, employers and government representatives negotiate wages and other industrial relations issues- and laws that are created by the state to limit struggles around the wage rate. Secondly, through a larger, democratic space in strikes or demonstrations are staged. Employers mostly pursue their interests through parliamentary, tripartite institutions and through occupying prominent positions in government structures. International markets affect the determining of wage policy through the actions of international and regional institutions that provide access to overseas debt, and who stipulate the conditions to be followed by the Indonesian government in receipt of this debt.
\end{abstract}

Keywords: state, minimum wage, policy, workers, trade unions, safety net. 


\section{Table of Contents}

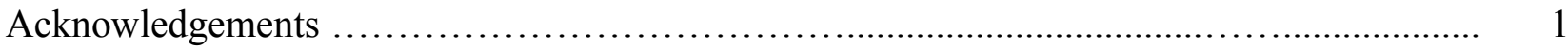

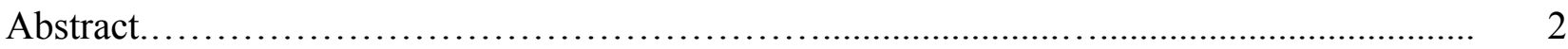

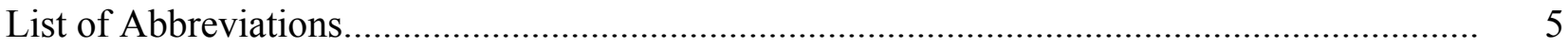

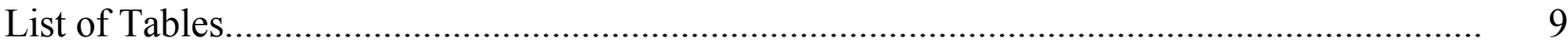

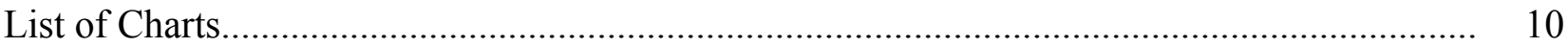

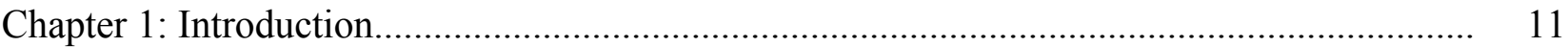

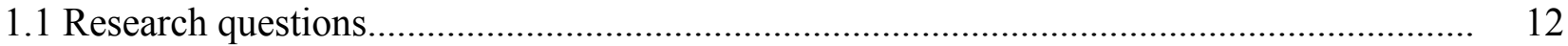

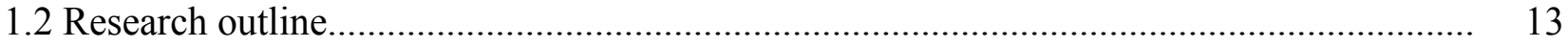

Chapter 2: Theoretical Frameworks, Methods and Data................................................... 15

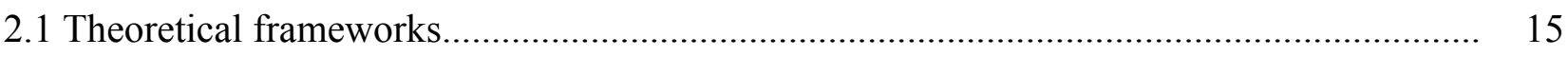

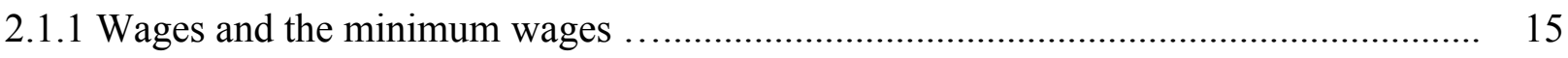

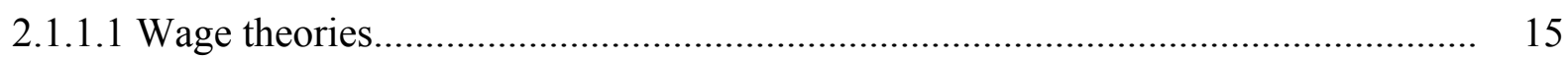

2.1.1.2 The minimum wages................................................................................... 18

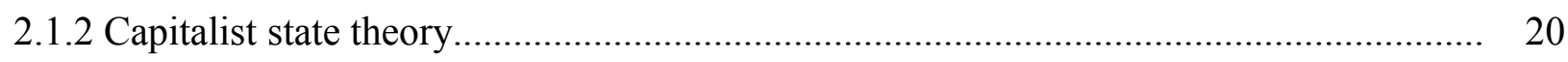

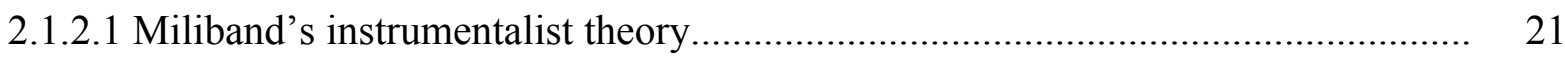

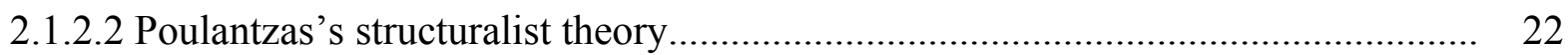

2.1.2.3 Jessop's strategic relational approach.......................................................... 24

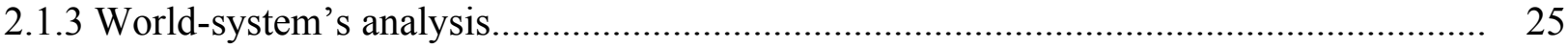

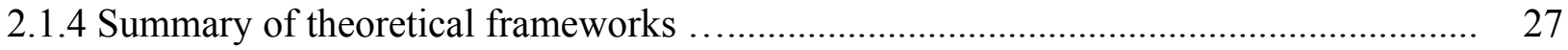

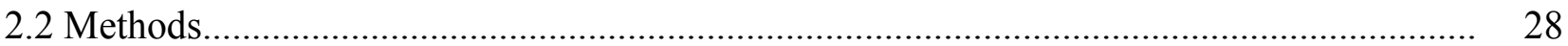

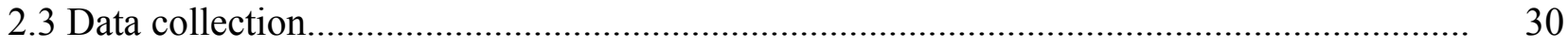

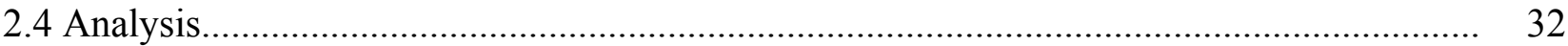

Chapter 3: A Brief History of the State, Workers and Employers in Indonesia......................... 34

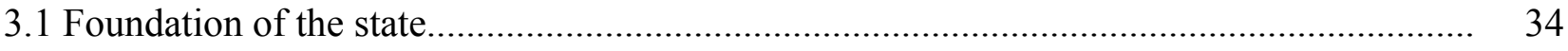

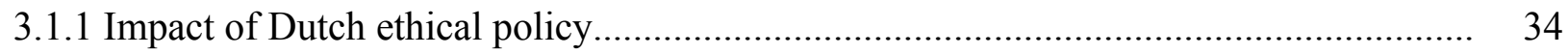

3.1.2 Emergence of the social justice concepts.............................................................. 36

3.2 Trade unions from Dutch colonization to the New Order ............................................ 37

3.2.1 Dutch colonization.................................................................................................. 37

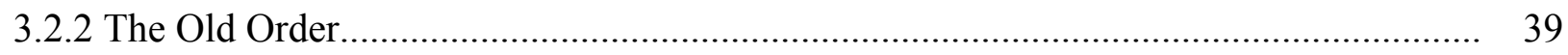

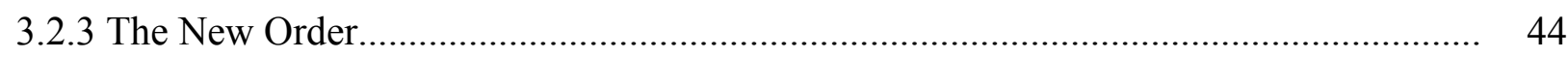

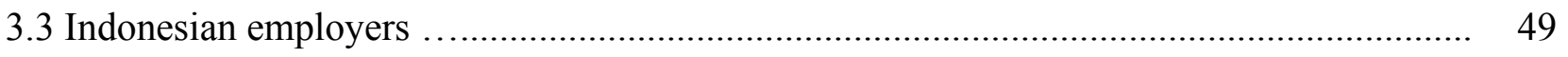




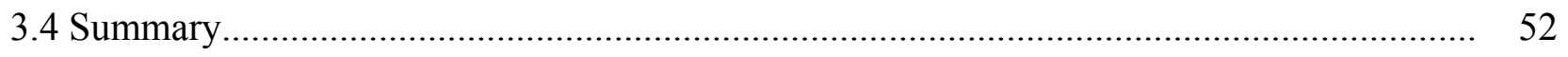

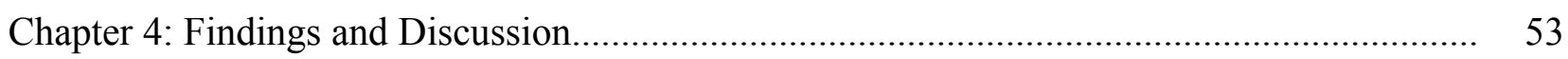

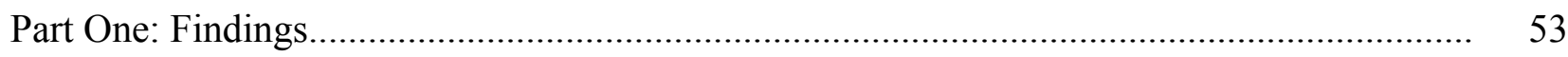

4.1 The influence of international capital....................................................................... 54

4.2 Minimum wage policy.......................................................................................... 56

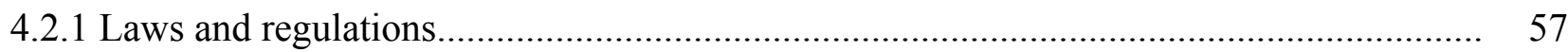

4.2.2 Minimum wage definition.................................................................................... 59

4.2.3 The formulation of minimum wage....................................................................... 61

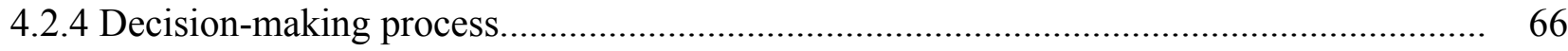

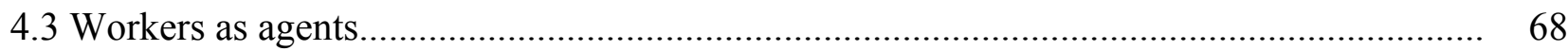

4.3.1 Minimum wage as a main issue for trade union.................................................... 68

4.3.2 Workers' struggles for minimum wage................................................................. 72

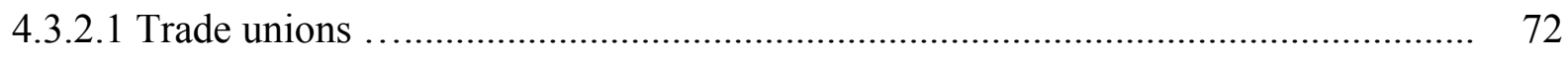

4.3.2.2 Trade union strategies.......................................................................... 78

4.4 The role of employers' organisations and politicians with employers background.............. 85

4.4.1 Employers' organisations..................................................................................... 86

4.4.1.1 Kamar Dagang Indonesia (KADIN, Indonesian Chamber of Commerce and

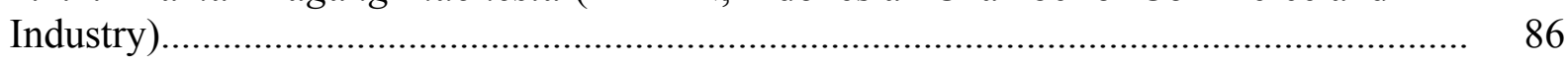

4.4.1.2 Asosiasi Pengusaha Indonesia (APINDO, Association of Indonesian

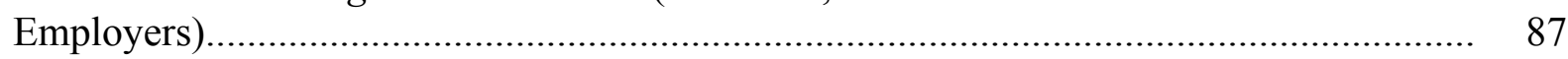

4.4.2 The employers in politics and government ...................................................... 88

4.4.2.1 KADIN and APINDO committees in politics and government............................. 88

4.4.2.2 Non-organisation employers in government and politics...................................... 89

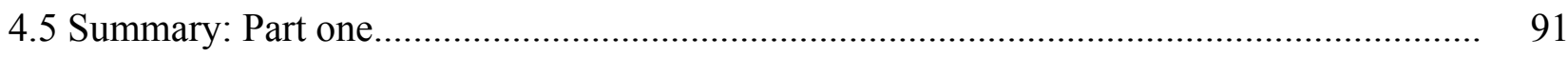

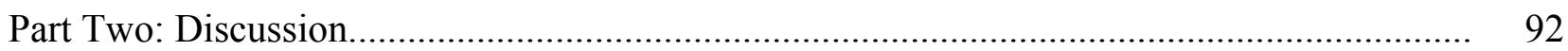

4.6 The influence of core-countries' interests on wage policy in Indonesia................................ 92

4.7 Workers' struggles and employers........................................................................... 94

4.8 The role of state to enforce conflict and continue capitalism............................................. 94

4.9 Strategic relational approach: Agency that fight within available structures....................... 96

4.10 Summary: Part two.......................................................................................... 97

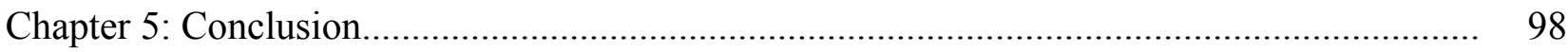

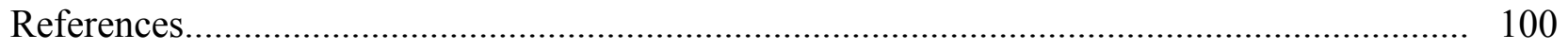




\section{List of Abbreviations}

AD

AIIB

ADB

APINDO

ASPEK Indonesia

Bappenas

BTI

CGI

DKI

Depekab

Depeko

Depenas

Depeprov

EIB

FB DKI Jakarta

FBSI

FES

FNPBI

FPBI

FSB Garteks

FSBI

FSPASI

FSPMI
: Angkatan Darat, The Military Army

: Asian Infrastructure Investment Bank

: Asian Developement Bank

: Asosiasi Pengusaha Indonesia, Association of Indonesian Employers

: Asosiasi Pekerja Indonesia, Indonesian Workers’ Association

: Badan Perencanaan Nasional, National Development Planning Board

: Barisan Tani Indonesia, Peasant Front of Indonesia

: Consultative Group on Indonesia

: Daerah Khusus Ibukota, Special Region of the Capital city

: Dewan pengupahan kabupaten, the District Wage Council

: Dewan pengupahan kota, the City Wage Council

: Dewan pengupahan nasional, the National Wage Council

: Dewan pengupahan propinsi, the Provincial Wage Council

: European Investment Bank

: Forum Buruh DKI Jakarta, Trade Unions Forum DKI Jakarta

: Federasi Buruh Seluruh Indonesia, All-Indonesia Workers

Federation

: Friedrich-Ebert-Stiftung, Friedrich-Ebert Foundation

: Front National Perjuangan Buruh, National Front for Indonesian Workers Struggle

: Federasi Perjuangan Buruh Indonesia, Federation of Indonesian

Workers' Struggle

: Federasi Serikat Buruh Garmen dan Tekstil, Federation of Garment and Textile Trade Union

: Federasi Serikat Buruh Indonesia, Federation of Indonesian Trade Unions

: Federasi Serikat Pekerja Aneka Sektor Industri, Federation of Workers'

Unions of Various Sectors of Indonesia

: Federasi Serikat Pekerja Meta Indonesia, Federation of Indonesian Metal

Workers' Union 
Gaspermindo : : Gabungan Serikat Pekerja Merdeka, Indonesia Federation of Free Trade Unions

GBI

: Gabungan Buruh Indonesia, Indonesian Workers Alliance

GOBSI

: Gabungan Organisasi Buruh Seluruh Indonesia, Federation of all Indonesian Worker Organisations

GOLKAR : Golongan Karya, the Party of the Functional Group

GERWANI : Gerakan Wanita Indonesia, Indonesian Women's Movement

GSBI

: Gabungan Serikat Buruh Indonesia, Federation of Indonesian Trade Unions

HIP

IDB

: Hubungan Industrial Pancasila, Pancasila Industrial Relations

IFAD

: Islamic Development Bank

IGGI

: International Fund for Agricultural Development

ILO

: Inter Governmental Group on Indonesia

IMF

: International Labour Organisation

INFID

: International Monetary Fund

ISDP

KADIN

: International NGO forum on Indonesian Development

: Indische Sociaal-Democratische Party, Social Democratic Party of the East Indies

KASBI

: Kamar Dagang Indonesia, Indonesian Chamber of Commerce and Industry

: Kongres Aliansi Serikat Buruh Indonesia, Congress of Indonesian Unions

Alliance

Kepmen : Keputusan menteri, Ministerial decree

Kepres

: Keputusan presiden, Presidential decree

KPBI

: Konfederasi Perjuangan Buruh Indonesia, Confederation of Indonesia

Workers Struggle

KPO PRP

: Komite Persiapan Organisasi, Perhimpunan Rakyat Pekerja

Organisation Preparation Commitee, Working People Association

KPRI

: Konfederasi Pergerakan Rakyat Indonesia, Confederation of Indonesia People's Movement

KSBSI

: Konfederasi Serikat Buruh Sejahtera Indonesia, Confederation of Indonesian Prosperity Trade Unions

KSPI

: Konfederasi Serikat Pekerja Indonesia, Confederation of Indonesian

Workers' Union 
KSPSI

LBH

LoI

LIPI

LIPS Sedane

MA

MK

MPBI

MPR RI

NGO

OPSI

PDIP

PKI

PP

PPBI

PPP

PUSPI

PVPN

RI

SAP

SBSI 92

SI

SOBSI

SPAI-FSMI
: Konfederasi Serikat Pekerja Seluruh Indonesia, Confederation of All Indonesian Workers' Union

: Lembaga Bantuan Hukum, Legal Aid Institute

: Letter of Intent

: Lembaga Ilmu Pengetahuan Indonesia, The Indonesia Institute of Sciences

: Lembaga Informasi Perburuhan Sedane, Sedane Labour Resource Centre

: Mahkamah Agung, Supreme Court

: Mahkamah Konsitusi, Constitutional Court

: Majelis Perjuangan Buruh Indonesia, Indonesian Labourers-Workers

Council

: Majelis Permusyawaratan Negara Republik Indonesia, People

Consultative Assembly of the Republic of Indonesia

: Non-Government Organisation

: Organisasi Pekerja Seluruh Indonesia, All Indonesian Workers-

Organisation

: Partai Demokrasi Indonesia, Indonesian, Democratic Party

: Partai Komunis Indonesia Indonesian, Communist Party

: Peraturan Pemerintah, Government regulation

: Pusat Perjuangan Buruh Indonesia, Indonesian, Workers Struggle

: Partai Persatuan Pembangunan, United Development Party

: Badan Permusyawaratan Sosial Ekonomi Pengusaha Seluruh

Indonesia, Employers' Council on Socio-economic Affairs

: Persatuan Vakbond Pegawei Negeri, Civil Service Trade Union

: Republik Indonesia, Republic of Indonesia

: Structural Adjustment Programme

: Serikat Buruh Seluruh Indonesia 92, Confederation of Indonesia Prosperity Trade Unions of 1992

: Sarikat Islam Islamic union

: Sentral Serikat Buruh Seluruh, All-Indonesia Central Labour Organisation

: Serikat Pekerja Aneka Industri-Forum Serikat Metal Seluruh Indonesia,

Various Industry Workers' Unions-Federation of Indonesian Metal Workers'

Union 
: Serikat Pekerja Nasional, National Workers' Union

SPSI

: Serikat Pekerja Seluruh Indonesia, All Indonesian Workers' Unions

TURC

: Trade Unions Rights Centre

UMK

: Upah Minimum Kabupaten, District/city minimum wage

UMSK

: Upah Minimum Sektoral Kabupaten, District/city sectoral minimum wage

UMP

: Upah Minimum Propinsi, Provincial minimum wage

UMSP

: Upah Minimum Sektoral Propinsi, Upah Minimum Provincial sectoral minimum wage

UNICEF

: United Nations Children's Fund

UUD

: Undang-undang dasar, Constitution of Indonesia

VSTP

: Vereniging v. Spoor en Traam Personnel, Trade Union of Rail-road and Tram labour 


\section{List of tables}

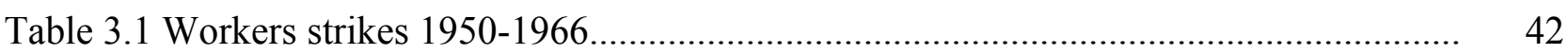

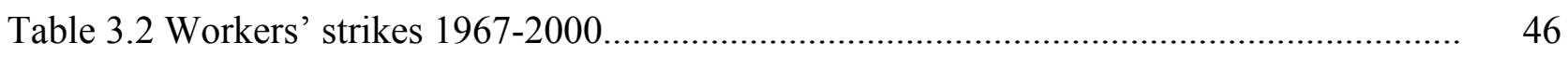

Table 4.1 The comparison of the number of components of the decent living needs between PP No. PER-17/MEN/VIII/2005 and PP No. 13/2012 _............................................................ 62

Table 4.2 The number of violations of minimum wage, overtime payment, and annual allowances 2011-2017.

Table 4.3 The comparison of the average minimum wage at national level, minimum wage increase, and the average decent living needs 2010-2017.

Table 4.4 The number of confederations, federations, and trade unions in the factories in Indonesia 2010-2017.

Table 4.5 The number of complaints on labour relation, freedom of association and criminalisation of trade unions activists 2011-2017.

Table 4.6 The number of strikes, workers involved and the hours lost 20102017

Table 4.7 A summary of the 2012 workers strikes. 


\section{List of charts}

Chart 4.1 The minimum wage formulations based on the Government Regulation No. 78 of 2015 


\section{Chapter 1: Introduction}

In both developed and developing countries, minimum wages are still inadequate for covering the living needs of workers. The US Government Accountability Office (2017) reported that approximately 40 per cent of workers with a family who earn minimum wages US\$16 or below, live in poverty. In Germany, a study indicated that minimum wages are still below the purchasing power parity (PPP) among the seven leading European countries (Schulten, 2014).

The same conditions also occur in developing countries such as Indonesia. A study on minimum wages in Indonesia have found that the minimum wage has not been adequate to protect or improve the welfare of workers; minimum wages have limitations in improving living standards and reducing inequalities (Yamada, 2016, p. 1). Similarly, Institut Kajian Krisis dan Strategi Pembangunan Alternatif (INKRISPENA, Research Centre for Crisis and Alternative Development) found that wages earned by workers are not sufficient to afford decent living conditions. On the other hand, the weakness of the social protection system makes the life of workers worse; they have to pay for various needs outside the cost components covered in the minimum wage, such as healthcare costs. As a result, workers are trapped in cycles of debt and poverty (INKRISPENA, 2017). Research conducted by Akatiga, Centre for Social Analysis, states that the average wage of workers only cover 74.3 per cent of the average real spending. While Upah Minimum Kabupaten (UMK, the district minimum wage) only covers 62 per cent of the average worker's expenditure per month (Tjandraningsih, 2009, p. 22).

Workers' dissatisfaction with the inability of the minimum wage to meet decent living needs is evidenced in various strikes demanding a rise in minimum wages around the world. From 2012 -2017 , demands for minimum wage increases were advanced by fast food workers in the US. In India, around 180 million workers participated in a simultaneous demonstration demanding a minimum wage increase to US\$9 per day by 2016 (Workers strike back, 2016). In 2017, workers in Myanmar demanded a 56 per cent minimum wage rise to US\$4.14 per day (Tomiyama, Asia Nikkei, 2016). In Indonesia, demonstrations demanding minimum wage rises are regularly organised by workers, both on Mayday and sequential actions towards minimum wage determination in October and November. But their struggles to seem to fail when dealing with the power of capital. 
The minimum wage policy is a tool to protect workers' welfare and reduce poverty. This point was discussed in the 104th General Conference of the International Labour Organisation (ILO), relating to the ILO Declaration on Social Justice for Fair Globalization, which stated that the minimum wage is used by governments and social partners to provide protection for workers, and that the protection should be appropriate for workers' and their family's needs (ILO, 2015, p. 3). The ILO also states that a properly designed and effective minimum wage would contribute to the achievement of goal 10 of the 17 Sustainable Development Goals (SDGs), which aims

reduce inequality within and among countries, emphasizing income growth of the bottom 40 per cent of the population, the elimination of discrimination, as well as the adoption of policies, especially fiscal, wage and social protection policies, and progressively achieve greater equality (ILO, n.d., para. 3).

Minimum wage policy-making offers a compelling opportunity to examine the role of the state in social policy. The direct involvement of various parties and interests, such as employers and workers, affects minimum wage rate.

The role of the state in social policy-making is influenced by various interests. A study conducted in European states showed that the role of the state in social policy is a representation of economic, political and ideological interests, particularly with the declining influence of workers (Baylis et al., 2016). Another study found that the role of the state in social policy is related to various economic interests and that growing international market influences have been affecting national economic strategies and social policy (Falkner \& Talos, 1994). Gough's (2014) study of some developing countries found that the history of the state, culture and globalization influenced states' development of social policies. Thus, the government is not the only factor in social policymaking and factors outside the state must also be considered.

\subsection{Research questions}

In Indonesia, the minimum wage is managed by the government through various regulations, especially through the Ministry of Manpower. The Indonesian government enacts some regulations as a foundation of tripartite negotiations. Here, they are often seen as taking sides. Workers regularly accuse the state of furthering employers' interests over the needs of workers. At other times, employers allege that policies stipulated by the government are not appropriate to the current 
economic crisis. Employers often argue that the crisis has made it difficult to find a market for their products and that it is hard to obtain sufficient returns on their investments. Therefore, this study aims to examine the role of the State in minimum wage policy-making. This more general question leads to specific questions as follows:

1. What does the State do to accommodate the demands and pressures from workers, employers and the international market?

2. What strategies are developed by the workers in influencing the state?

3. How do employers influence the policy process?

In an effort to answer these questions, this study will draw on theories of the capitalist state developed from within a Marxist perspective-including the work of Miliband, Poulantzas and Jessop, as well as the analysis of the world-systems analysis approach pioneered by Wallerstein. The challenge for this study is the lack of literature that applies theories of the capitalist state to social policy and labour issues in Indonesia. Therefore, this study also aims to contribute to the development of these theories in the analysis of social policy as well as labour studies in Indonesia. This study is expected to contribute to the development of trade union movement strategies to achieve their welfare goals.

\subsection{Research outline}

The information gathered during the research period is presented and analysed over six chapters. Chapter one provides an introduction for this study. It states the research questions and the aims of the study. Chapter two covers the theoretical framework that is used to analysis the role of the state and a brief description of wages and minimum wage concepts. This chapter also explains the methodological process followed in this study. Chapter three provides summaries from some literatures about the form of Indonesia as a state and how social classes were established and become the foundation for the relationship between structure and agency in the wage policy process. Chapter four divided into two parts. Part one describes the findings of the study, such as the regulations related to minimum wage policy; the process of minimum wage policy-making; the institutions and the strategies of workers, employers and the international market. Part two discusses the relationship between the structures and actions of major social actors. It also discusses 
the demands and pressures put on the state. Chapter five provide a summary of how the state exercises power in wage policy-making. 


\section{Chapter 2: Theoretical Frameworks, Methods and Data}

This section discusses the theoretical frameworks to be used in answering the research questions about the role of the state in minimum wage policy-making. It consists of three sections: the wage and minimum wage; capitalist state theory; and world-systems analysis. This chapter also describes the research methods used in this study and how data was collected and analysed.

\subsection{Theoretical Frameworks}

Minimum wage setting reflects the role of the state in policy-making in relation to workers' welfare. As mentioned in chapter one, various parties, such as employers and workers, influence the policy-making process. Also, the labour policy at the state level cannot be separated from the global context.

Theories of the capitalist state that have originated in Marxist tradition and world-systems analysis will be utilised to understand the role of the state, along with its intersection with other influencing factors. Before discussing theories of the capitalist state and world-systems analysis, this chapter will briefly explain wage theory and the minimum wage so as to contextualise the minimum wage framework.

\subsubsection{Wages and the minimum wages}

\subsubsection{Wage theories}

In general, wages are a reward for work as a factor of production that is sold by a worker to companies. Wage rates are the most common source of disputes between workers and companies. Most workers' protests in Indonesia are related to wages. Workers frequently assert that companies pay low wages that are not commensurate with the workers' outputs. But how are wages determined? Many theories explain the mechanism of wage formation, or the determination of wage levels, these include: subsistence theory; wage-fund theory; surplus value theory; residual claimant theory; marginal productivity theory; bargaining theory; and behavioural theory. 
The subsistence wage theory was proposed by David Ricardo and is based on the population theory of Thomas Malthus. It rests on the notion that wages are always at an equilibrium with the labour market, when the number of workers increases wages will decrease and vice versa (Henri, 2015). Therefore, wages need not meet the minimum required for survival, as it is the market's ability to absorb workers that determines remuneration rates. This logic still influences the decisionmaking of governments and employers when dealing with workers.

The wage-fund theory was developed by James Mill, J. R. McCulloch, and John Stuart Mill. The wage-fund theory states that labour costs depend on the amount of relative capital available for wage-funds and the size of the labour force. The wage-funds are a part of the national income set aside for the purchase of labour. Based on this theory, wage increases and growing demand for workers depends on wage-fund increases (Satiropoulos \& Economakis, 2008). Thus, the regulation of workers' wages through law does not affect wage rates.

Residual claimant theory was developed by Francis A. Walker. According to this theory, wages are the amount remaining from industrial revenues after deducting rent, interest, and profit (Agba \& Ushie, 2013). Payments on the factors of production of land (rent) and capital (interest) are based on contracts between individuals, while payments on entrepreneurial production factors (profit) are obtained by adopting certain principles, such as how much the employers want to gain from his entrepreneurial ability, or how much profit he would expect from managing other factors of production.

Payments on workers factors (wages) are determined after the previous three factors of production. As with the theory of wage-fund and subsistence wage theory, the residual claimant theory also overrides the role of workers' struggles to demand increases in wages.

Marginal productivity wage theory was formulated in the late 19th century by F. W. Taussig. Therefore, this theory is also called the Taussig Theory of Wages. This theory states that the wage rate is equal to the value of the marginal product of the final hired worker (Felipe $\&$ McCombie, 2014; Taussig, 1910). The marginal productivity theory states that, under conditions of perfect competition, every worker of the same skill set and efficiency in a given category will receive a wage equal to the value of the marginal product of that type of worker (Fapohunda, 2012).

The bargain theory of wages is a critical extension from the historic theories, together with an examination of certain wage factors: the mobility of workers, trade unionism and the methods of industrial remuneration. The historical development of the theory of wages is summed up in three systems: subsistence theory, wages-fund theory and productivity of labour theory. According to the 
bargain theory of wages, the actual determination of wages depends on the relative power of the workers and employers within the bargaining process. This relative power in bargaining is the result of many conditions. On some occasions, workers may succeed in having their demands met, either from the state in terms of pro-labour policy or from individual employers in the form of wage increases or improvements in working conditions. But such achievements are not permanent, as the balance of power between workers and employers is dynamic and changes over time (Vint, 2017).

The last wage theory is Karl Marx's surplus value theory. According to Marx, the general condition of wages chiefly depends on two factors: the cost of the reproduction of labour power and class struggle. A worker's wages increase by sacrificing the wages of other workers and at the expense of the employer's profits (Abalos, 1998).

Classic theorists, such as Mill and McCulloch, argued that the overall wages of workers cannot exceed the wage fund. The wage rise of a number of workers will lead to a decrease in other workers' wages, therefore the wage fund will remain constant. According to Marx the total combined amount of workers' wages and employers' profit is constant. An increase in the former leads to a reduction in the later, and vice versa.

For the purposes of this study, the wage theories can be categorised into two groups: one which ignores the subjective factor of the struggle or the bargaining power of the workers; and one which includes the factor of workers' struggles in determining wage rates. Included in the second group are: the bargain theory and surplus value theory, both of which are concerned with the role of workers' struggles. The other theories fall into the first group.

Surplus value theory balances the external, objective economic conditions against the subjective dimension of workers' struggles. Bargain theory emphasizes the role of workers' struggles as a factor that is more important than others. Marx's wage theory better explains the conditions in Indonesia. The next chapter will further discuss the role of workers' struggles in raising wages and how these struggles are constrained by wider economic conditions. When the economy is in a period of financial crisis, or when the state must maintain Indonesia's international competitiveness to attract foreign investment, workers' demands will be of less concern for decision makers. For example, Government Regulation No. 78 of 2015 on wages, which will be discussed in the findings chapter, is an example of how the president prioritises the interests of foreign investment inflow than demands of the workers. 
As with Ricardo, Marx's wage theory recognises that labour market prices, or wages, are governed by the economic law of price formation based on the labour value theory. Like Malthus and Ricardo, Marx stated that fluctuations in the wage rate revolve around its value. While Ricardo sees worker population figures as the determining factor of wage increases and decreases, Marx assumes that the wage rate is determined by the proportion of the necessary workers set against those who are 'surplus' to the requirements of capital (Abolos, 1997-1998).

Classical theorists, like Ricardo and Mill, did not recognise the role of wider social conditions in the formation of wages, in their view wages are solely determined by economic law. An increase in the wages of one worker will be at the expense of other workers' wages. Instead, Marx acknowledges the role of social conditions, especially the workers' struggle. Workers' struggles to increase wages, and the increase in wages that can occur by cutting employers' profits, rather than cutting the wages of other workers.

\subsubsection{The minimum wages}

The concept of the 'minimum wage' is unfixed and varied. It does not have a single definition. A study of the minimum wage in Vietnam defined it as "the lowest wage level paid to the employees who are unskilled, do the simplest jobs in the normal working conditions, able to meet the minimum living standards of workers and their families" (Dieu, 2012, p. 5). The International Labour Organisation (ILO) defined the minimum wage, in 1967, as "the wage which in each country has the force of law and which is enforceable under threat of penal or other appropriate sanctions" (ILO, 1992 as cited in Eyraud \& Saget, p. 3). The ILO definition was updated in 2014, holding it to be "the minimum amount of remuneration that an employer is required to pay wage earners for the work performed during a given period, which cannot be reduced by collective agreement or an individual contract" (ILO, n.d., para. 1). The ILO also provides guidelines on how to account for a fairer wage for workers and their families (Reynaud, 2017, p. 1).

Different countries use various models to determine the minimum wage. The first model involves the state not specifying the minimum wage, allowing the value of wages to be set by the labour market. The second model is the collective bargaining method, or through social partners, which allows a designated agency to determine wages. The third model sees the state involved in wage determination. This model can take three forms: the government acting alone in setting wage 
rates; the government determining wages through consultation with social partners; or the government following the recommendations or consultation of a specialised body (ILO, 2010; Boeri, 2009). Indonesia has adopted the later version of this model. The Indonesian government has established a wage council, which is a tripartite institution. Wage council consists of trade unions, employers and government representatives. The Indonesian wage council will be discussed at length in chapter four.

According to Belsier and Rani (2014), for policy-makers the question is not whether the state will implement a minimum wage. But rather, how the state will operate the minimum wage system to reduce disadvantages and increase potential advantages. Therefore, the form of the minimum wage, and how it operates, depends on both internal and external factors both of which may benefit the country. Some of these factors can be traced in Indonesia's history. The history of minimum wage setting began in New Zealand and Australia, with both applying a minimum wage in the late 19th century. Britain adopted this concept in 1909, but it only covered certain industries (Seekings, 2016; Barry \& Brosnan, 2006). In 1928, the ILO adopted the Minimum Wage-Fixing Machinery Convention for the first time and encouraged other countries to follow the system deployed in Britain.

Many countries did not implement the ILO convention for the following reasons: it only encouraged the protection of the workers' wages in particular sectors; it primarily addressed the lowest-paid workers' wages; and it was only relevant to sectors with weak collective bargaining power. ILO Convention No. 26, for example, is limited to the manufacturing and trading sectors and excludes the agricultural industry.

After World War II, the idea of a national minimum wage was accepted in France. The application of a national minimum wage was in the context of widespread poverty and rising prices in the post-war period. The ILO then adopted the concept of a national minimum wage and enacted the Minimum Wage Fixing Recommendation No. 135 on the national minimum wage. The 1973 oil shock crisis affected the implementation of a minimum wage in developing countries. International financial institutions, such as the IMF, required them to adopt structural adjustment policies and repealed the outcome of the ratification of the minimum wage convention. In the wake of the Washington Consensus, which suggested developing countries should have flexible labour markets, some countries slowly reduced minimum wage-related policies (Belser \& Rani, 2015). However, some internal factors to a state, such as unemployment and trade unions, pushed some countries to change the form of the minimum wage-from a sectoral to a national minimum wage. External 
factors to a state, such as war, international humanitarian organisations and international financial institutions, also supported or constrained how minimum wage policies operated within a country.

The irregular character of minimum wage implementation, however, indicated the relevancy of Marx's theory of wages. The workers' struggle demanded wage rises and a call for the state to protect the rises; both aspects of the struggle occurred within the constraints of the wider economic context. When capitalism is in crisis, the companies will depress the workers wage rather than sacrifice their own profits.

\subsubsection{Capitalist state theory}

Sociology has two major schools of state theory, one is society-centred and the other state-centred . Max Weber and Karl Marx provided the discipline with substantial and weighty views on the state; (Poggi, 1978). Weber opened the state-centred approach, and Marx the society-centred one. Gianfranco Poggi argues Marx's approach has been the more influential, holding that "We owe much of the current literature on the state (in sociology as well as in other social sciences) to students who appeal primarily to Marx for their inspiration" (Poggi, 1978, p. V). The supporters of the society-centred approach do not form a homogeneous group. They are primarily divided between instrumentalists and structuralists, with other groups trying to bridge the debate between the two. Miliband held the state was an instrument of power wielded by the dominant class to impose its interests on other social classes. Poulantzas considered Miliband's view to be "instrumentalist". The instrumentalist view emphasises the subjective factor of social classes in influencing the state; it is therefore considered an agency-focused approach. On the other hand, Poulantzas and the structuralists argued that the state structurally plays a role in preserving capitalism by intervening to overcome crises within the economic system. This means that the role of agency, such as workers and employers, in influencing the state is not a major factor.

The peak of the debate, as well as the beginning of a discussion between structuralists and instrumentalists, occurred between 1960-1970. This debate was conducted between Ralph Miliband, who was an instrumentalist, and Poulantzas who was a structuralist. As Jessop (2018) notes,

the work of Miliband and Poulantzas were part of the general revival of Marxist interest in the state during the 1960s and 1970s, which arose in response to the state's apparent ability to manage the 
postwar economy in advanced capitalist societies and to the 'end of ideology' that allegedly resulted from postwar prosperity (p. 135).

While both Poulantzas and Miliband refer to the works of Marx and Engels when theorising the State, Poulantzas assumed a different position on the issue. He viewed the State as the intermediary of class-conflict. According to Barrow (1993),

the function of the state is to protect and reproduce the social structure of capitalist societies ...insofar as this is not achieved by the automatic processes of the economy. ...the state policies and state institutions are best understood by their 'function' in maintaining the capitalist system (p. 51).

Some state theorists have tried to synthesis the positions held by Miliband and Poulantzas. One such theorist was Bob Jessop, who claimed that state power cannot be simplified as a political force of the governing interests (Barrow, 1993). Based on that understanding Jessop developed the strategic relational approach (SRA), which will be discussed in the following sections, after a review of Miliband's instrumentalist theory and Poulantzas's structuralist theory.

\subsubsection{Miliband's instrumentalist theory}

According to Newman, Miliband's Marxist theory of the state contributed to his being "probably the most influential Marxist political sociologist writing in English in the second half of the twentieth century, [with] his output simultaneously contributing to both the academic research agenda and to student protest movements of the era" (Newman 2007, p. 176).

Miliband's book, The State in Capitalist Society, written in 1969, challenged the dominant pluralist view of the state. This view held that all classes and social groups have equal access to state power. Miliband criticised this position, and sought to prove that social classes and groups within society do not have equal access to power. The state, for him, is chiefly a ruling class instrument for imposing its interests through policies and regulations. According to Barrow (1993), the primary premise of the instrumentalist approach is that 
modern capitalists are able to formulate public policies which represent their long-term class interests and to secure the adoption, implementation, and enforcement of those policies through state institutions. Thus, the instrumentalist theory offers a straightforward and simple claim that the modern state serves the interests of the capitalist class because it is dominated by that class (p. 13).

To prove this premise, Miliband researched power structures. First, he mapped the classes in the society based on the control of economic resources. He placed the politicians, civil apparatus, prosecutors, and military personnel as the non-class element-as they are considered to be professionally concerned with the running of the State. Second, he examined how the class that controls the economic resources can affect the state subsystem. The state subsystem consists of the government, the administration, the military and the police, the judicial branch, the sub-central government, and the parliamentary assemblies. These six elements exercise power within the state.

Miliband's study focused on the dominant class mechanisms, as tied to economic power, and how this influenced the ruling of the state and controlling the state subsystem. The first mechanism is the direct involvement of the capitalists in the state subsystem. The second mechanism is revealed through studying the social background of 'state elites' - it relates to the education backgrounds and recruitment processes of those occupying positions within the state apparatus, such as bureaucrats, prosecutors, and the military. This mechanism serves as a filter that ensures that those coming into the state apparatuses come from the capitalist class or at least accept capitalism as the ideal system. In the contemporary Indonesian context, this instrumentalist premise can easily be verified by mapping the class background of government officials, as will be discussed in chapter four of this thesis.

\subsubsection{Poulantzas' structuralist theory}

In working from a structuralist position, Poulantzas does not view the conflict among social classes as a determining factor for the role of the state. As the intermediary of the conflict among classes, the state can stand between the interests of different classes, or class factions. This does not mean that the state will tend towards neutrality. The state structure maintains capitalism. Poulantzas argued that the state is the factor "which concentrates, condenses, materialise and incarnates politico-ideological relations in a form specific to the given mode of production" (Poulantzas 1978, p. 27). In affirmation of Poulantzas' position, Barrow (1993) argued 
The function of the state is to protect and reproduce the social structure of capitalist societies ...insofar as this is not achieved by the automatic processes of the economy. ...state policies and state institutions are best understood by their 'function' in maintaining the capitalist system (p. 51).

Here, the state is seen as a superstructure that reflects the mode of production as a base structure. The state has a role in maintaining the continuity of the capitalist mode of production during periods of severe crisis conditions. The crisis can be either a decline in the rate of capitalist accumulation or a critical conflict between classes, in this case between workers and employers.

Instrumentalists hold that the struggle between classes determines the role of the state, and the ruling class will assign state policy. Whereas structuralists view class struggle as a product of crises in the base structure, to which the state naturally responds. Accordingly, to prove this premise, the focus of structuralist research is on state policy, which is assessed in terms of its impact in resolving a crisis in the capitalist economic system.

In this thesis' research, with its focus on workers' wage policies in Indonesia, the structuralist approach is used to reveal the relationship between government regulations on wagesetting principles and mechanisms that have economic and political functions. When an economy is sluggish, the state tends to play a protective role against investment (entrepreneurship), restraining capital flight and seeking to avert the bankruptcy of national capitalists. An outcome of this being that wage conditions will be kept at a constant level to smooth the operations of companies.

In a period of crisis, demand decreases and causes profit to also decrease; even if it reaches the break-even point of costs. To offset the decline in income, employers typically reduce production capacity, which includes dismissing their workers. Meanwhile, to prevent mass lay-offs, the government keeps the wages of workers from rising with the aim of avoiding the additional burden of cost on employers. The government adjusts the minimum wage policy in line with economic growth and inflation. The adjustment takes place at the level of wage calculation formulas and is processed in tripartite institutions, which will be discussed in chapter four. Following Marx's theory of wage formation, the workers' struggles for wage rises is seen to force employers to decrease their profits while also remaining subject to wider economic conditions. During a crisis it is difficult to raise wages due to such factors as inflation and purchasing power. 


\subsubsection{Jessop's strategic relational approach}

Jessop sought to synthesise the positions of the instrumentalists and structuralists. He suggested that the debate between them need not happen because they were each focused on different issues.

According to Jessop, this debate was between the state in capitalist society approach versus the capitalist type of society approach. "The approach used by instrumentalists is from concrete to complex analyses of political struggle, while structuralist approaches moved from abstract-simple to concrete-complex concepts" (Jessop 2013, p. 16). Therefore, Jessop characterised this debate as “the Dialogue of the Deaf” (Jessop, 2008, p. 132).

Jessop developed a new approach encompassing the relationship between agency and structure. He called this the strategic relational approach (SRA). SRA holds that state power can be seen as a material condensation of the balance of class forces in struggle (Jessop, 1990). He suggested the need to examine

two interrelated aspects of the state system. First, to investigate the state form as a complex institutional ensemble with a specific pattern of strategic selectivity which reflects and modifies the balance of class forces. Second, to consider the constitution of these class forces and their strategies themselves, including their capacity to reflect on and respond to the strategic selectivity's inscribed within the state apparatus as a whole (p. 51).

In other words, the struggle of social classes or interest groups takes place within a structural frame the institutions and mechanisms governed by the legislation. However, institutions and legislation, as structural elements, are shaped by class struggles and interest groups.

Using the SRA, Jessop did not only look to the form of the state in his analysis, but also to the "social classes as struggling forces and as the structural and conjuncture factors that determine the balance between these forces" (Jessop, 1990, p. 149). The SRA investigates "the dialectical relationship process between structure and agency or action" (Jessop as cited in Lin, 2016, p. 752). The structure can be treated as "strategically-selective in their form, content, and operation; and actions are likewise treated as structurally constrained, more or less context-sensitive, and structuring" (Jessop, 2005, p. 48). Furthermore, Jessop suggested that strategic selectivity can be examined by looking at how specific structures "may privilege some actors, some identities, some strategies, some spatial and temporal horizons, some actions over others" (Jessop 2015, p. 48). These actors or social groups realise the privilege of other actors or social groups and then conduct 
a strategic-context analysis to develop strategies (Jessop, 2015)

For the research conducted in this thesis, Jessop's SRA is useful for assessing how the roles of key actors — such as trade unions, employers, and governments — within wage council are limited by higher legislation and other structures within the state. The wage agreements that are produced by actors in a tripartite council, or tripartite negotiation, are limited by the scope of regulations issued by the Ministry of Manpower. Similarly, the wage policy issued by the Ministry of Manpower will depend on policies to protect investments made by the Ministry of Industry and Commerce.

Furthermore, SRA assists this research by highlighting that there is no single policy that is produced by a single agency that sets the terms by which the minimum wage is set. Frequently, a policy is a result of other policies that have been issued by various institutions which also play a role in exercising state power. In each institution, demand and pressure is asserted from each agent in an attempt to get their interests accepted. The minimum wage policy, which will be explained at length in chapter four, is also influenced by a number of institutions and processes, including the trade policies processed by the Ministry of Trade and Industry, and monetary policies handled by the Ministry of Finance.

\subsubsection{World-systems analysis}

World-systems analysis offers another critical approach to analysing a country's role in policymaking, setting this within an international context. This approach is essential for understanding the situation in developing countries, such as Indonesia, which is a semi-peripheral capitalist country. World-systems analysis assumes that the division of labour is not only among classes in society but also between countries in the world capitalist system. The policy-making of peripheral countries is influenced by core countries. In other words, the core countries can influence other countries through their foreign policies.

This research will use two frameworks from the world system analysis: "the international division of labour' will be used to explain the place of the Indonesian state within the interstate system; and 'the interstate system' is conceptualised so as to explain the hegemony of the core over peripheral countries. Wallerstein introduced the concept of the international division of labour to world-systems analysis. This concept divides states into three categories: core, semi-periphery, and periphery, which are interdependent and interconnected within the global economic system. Firstly, 
Wallerstein described the existence of two interdependent regions: core and periphery. These interdependent regions have different production systems: capital-intensive production and labourintensive production, respectively (Goldfrank, 2000). Secondly, Wallerstein added a category entitled 'semi-periphery' to explain countries which have the same characteristics as the core but still have large areas of poverty.

Wallerstein (1978) believed that a significant factor in the structure of the world system is a power hierarchy between the core and peripheral regions - the powerful and wealthy core societies dominate and exploit the weak and poor peripheral societies. One means by which this dominance is exercised is the mastery of technology. The countries with advanced technology are at the core, and the less technologically developed are at the periphery. Mastery of technology also manifests in the form of patent rights that are owned by companies from developed countries. Developing countries have limited access to specific patented items and only undertake certain parts of production without access to the whole. Thus, this mechanism reproduces their subordinate status (Chase-Dunn \& Grimes, 1995). Wallerstein described this mechanism as an unequal exchange, involving the systematic transfer of surplus from semi-proletarian sectors in the periphery to the high-technology of the industrialized core. This mechanism leads to a capital accumulation process on a global scale and necessarily involves the appropriation and transformation of peripheral surplus (Goldfrank, 2000, p. 170).

Furthermore, the basic principle of the interstate system is the mutual co-recognition of states (Wallerstein, 2007). The interstate system consists of four relationships between strong and weak states. First, strong countries push other countries to open their markets. At the same time, strong countries protect their domestic market from any competitive products issuing from weak countries. Second, strong states control the policy-making processes in a weak country. This is often through influencing people in positions of power in weaker states. This can involve insuring these people receive and maintain position in key institutions, for instance within government, education institutions and state-owned enterprises. Third, the weak country is pressured to accept certain cultural practices by the strong country. It is propagated through linguistic policy, educational policy and mass media. Fourth, the strong country leads the formation of international policy and forces the weak country to obey their rules (Wallerstein, 2007).

In the interstate system, hegemony is a significant factor in maintaining the stability of the world-system (Wallerstein, 2004; el-Ojeili, 2015). Hegemonic countries can guarantee that the flow of capital will benefit the capitalist firms in their countries. 
Altogether, the interdependent relationship, between core, semi-periphery and periphery countries is used in this research to understand and analyse the influence of international factors influencing the setting of wage rates in Indonesia. For world-systems analysis, the wage policy in a particular country is not only influenced by the state structure, including legislation and institutions roles, and struggles for individual interests, but it is also affected by international factors. Examples of international factors could be the direct pressure of core countries. It could also be in the interests of Indonesia to keep its industrial products competitive against semi-peripheral and peripheral countries in the core states' markets. Indonesia takes account of how the wage rate should not drive investors into a competing country. In addition, Indonesia also ensures that wage rates do not make the prices of semi-finished goods sold to core countries more expensive than competing countries.

\subsubsection{Summary of theoretical frameworks}

This chapter outlined some theories from the Marxist perspective that will be used to analyse the role of the state and its relationship with workers and employers. Considering the workers' struggles and the economic constraints, surplus value wage theory is the most appropriate for the purposes of this study. Surplus value theory is in accordance with the minimum wage system applied in Indonesia. To set the minimum wage, the Indonesian government follows the recommendations of a specialised body, wage council. The Wage Council opens up the bargaining process among the state, workers and employers.

Capitalist state theories, such as instrumentalist, structuralist and the strategic relational approach, will be used to examine this process. The instrumentalist theory from Miliband will be used to investigate the social background of 'state elites', which can influence them to accept the idea of capitalism as an ideal system and perform their task of maintaining the capitalist system. The other capitalist state theory is Poulantzas's structuralism. The structuralist approach will be used to identify the relationship between government regulations on the wage-setting principles and mechanisms with economic and political circumstances. As well as Poulantzas, who believed that the state was as an ensemble of power, Jessop proposed the strategic relational approach to assess the role of diverse actors, including trade unions, employers, and the government.

As a semi-peripheral country, Indonesia is also affected by international interests when setting of its minimum wage. This study assumes that the capitalist state intends to keep the minimum wage rate in accordance with international market interests. To investigate the 
international influences on minimum wage policy, this study applies Wallerstein's world-systems analysis.

\subsection{Methods}

Chapter one outlined how this study would examine the role of the state in the creation of minimum wage policy. A minimum wage is one of safety nets that aims to ensure workers' welfare. Therefore, this study can be categorised as social policy research. According to Becker and Bryman (2005), policy research aims

to provide answers and evidence that can contribute to the improvement of policy and policymaking, can lead to better practice and interventions, the reduction of social problems and social distress, and the promotion of social welfare and social well-being. (p. 14)

As is the case for other social research disciplines, policy research typically utilizes three methods: qualitative, quantitative and mixed methods.

In this study, qualitative methodology was applied to examine the role of the state and the power relations that influenced minimum wage policy making. According to Creswell, qualitative research is "a means of exploring and understanding the meaning an individual or groups ascribe to a social or human problem" (as cited in Griffin, 2004, p. 6). Bryman and Becker (2012) have suggested some key characteristics of qualitative methods. First, qualitative methods are concerned with actors own meanings and therefore aim to examine a topic or issues from other people's perspectives. Second, this method is also concerned with the description of the research setting more than it is with explanation. Third it is the process in which events are viewed as unfolding and intertwined over time. Fourth concerns flexibility, qualitative study is mostly unstructured creating an opportunity for the researcher to grapple with unforeseen events and then change the research direction as necessary.

Studying the role of the state in minimum wage policy making necessitates the gathering of information from people who are directly and indirectly involved in the policy-making process. In this study, the people interviewed were directly involved in the process of minimum wage policy making, including members of wage councils who were workers, government officials and employers' representatives. The provincial governor and the Ministry of Manpower are included in the group. The people indirectly involved were groups or individuals who did not have access to the 
policy-making process but did have concerns regarding the minimum wage, including researchers, trade union officials who do not have representatives on wage council and NGO workers.

Qualitative methods also allowed this study to describe the role of the state and its relationships with other parties, such as employers, workers and the global market. Moreover, this study included some questions that aimed to describe the change of implementation of the minimum wage setting in wage council and the effort of the workers and employers to influence the minimum wage policy. This study did not restrict data collection to the minimum wage decisionmaking process in the Jakarta Wage Councils but attempted to see the interconnections between Jakarta and surrounding cities. Jakarta, as the capital city of Indonesia, acts as a benchmark on minimum wage determination for other areas. The minimum wage setting in Jakarta can potentially be seen to influence other areas.

The flexibility in using qualitative methods also allowed this study to change research direction as necessary. In the beginning, this study intended to investigate the relative autonomy of the state in minimum wage policy-making. After the data was collected, the findings led to another research direction; from the relative autonomy of the state to the role of the state in setting minimum wage policy. The initial data collected was inadequate to conduct an analysis of the relative autonomy of the state. Primary data in the form of, interviews with the Minister of Manpower and the Jakarta Governor could not be undertaken because of the difficulty of obtaining permits from the government. Secondary data from the media was incomplete so the information was insufficient to build arguments about the relative autonomy of state.

Mills et. al (2010) clarify some characteristics of the case study process. First is a focus on the interrelationships that constitute the context of a specific entity (such as an organisation, event, phenomenon, or person). Second is an analysis of the relationship between contextual factors and the entity being studied. Third is the explicit use of these insights (of the interactions between contextual relationships and the entity in question) to generate theory and/or contribute to existing theory (Mills, Durepos, \& Wiebe, 2010, p. 21). This method allowed for an exploration of all parties that influence the role of the state in the minimum wage policy making, such as the government, workers, the employers and the global market, and identified their relationships with one another.

This case study relied on minimum wage laws and regulations that were enacted after the reformation between 1998-2017. However, this study focused more on selected events between 2010-2017, than prior to 2010. This period was chosen because after 2010 workers' strike rates 
increased at the same time as the minimum wage rose. The wage increase was due to massive workers' strikes demanding a rise in wages. These strikes were triggered by several things, including the election of provincial governors or election of regent of districts and the strong organising capacities of trade unions. This was despite the number of workers who joined the unions declining during this period. At the time, Indonesia had three important political events. First was the regional head elections in 2010. Second was the legislative elections and presidential elections in 2012. Third was the regional head elections in 2017. The selected events impacted on other events and, sometimes, could be perceived as a series of events. This case study took some events that occurred in Jakarta and the surroundings satellite cities, such as Bekasi, Tangerang, Karawang, Depok, and Bogor. At this time, Jakarta and its surrounding cities were the strongest industrial areas in Indonesia. Therefore, the policy changes that happened in these areas can be seen to reflect policy changes throughout Indonesia. Also, the strikes in these areas could potentially have prompted workers in other provinces to strike. This study did not select one event to be deeply investigated because the study intended to examine the demands and the pressure on the state with regard to minimum wage policy making.

\subsection{Data collection}

This case study was designed to use multiple sources of evidence because a single source is inadequate for such research (Gilham, 2000). McGinn (2010) has suggested that multiple sources of evidence enable researchers to grasp the complexities of their case study, whereas a single source might cause inaccuracies. Thus, the data should be gathered from different perspectives or sources, including such documents and archival records as policy statements, guidelines, reports, letters, memos, meeting minutes, websites, brochures, and posters (McGinn 2010, p. 2).

The data collection was divided into stages between the collection of secondary sources in the form of documents and archival records as secondary and the conducting of interviews. Secondary sources that were accessible online were collected, such as government regulations, online newspapers, trade union blogs, and employers organisations' websites. These documents were sorted and separated into folders based on themes, i.e. minimum wage setting, trade unions, regulations and laws.

During the fieldwork stage of research in Indonesia data was gathered from official and nonofficial documents, such as the presentation files of wage council, newspaper clippings and official statistics from government offices. Some government institutions did not reply to the researcher's 
email requests for data and information related to this study. Other data was directly requested while conducting interviews. Some statistics and documents were downloaded from official NGOs and government websites.

Documentary videos were collected and viewed to note any relevant events. One of the documentary videos of particular relevance was entitled Bekasi Bergerak (Bekasi Workers Fight Back) and was produced by LIPS Sedane. This video recorded some workers' strikes in Bekasi in 2012. The complete list of the documentary videos called upon is provided in the reference section of this thesis.

The second stage of research was the conducting of interviews. An interview is a tool that enables the researcher to collect data interactively. Interviews can be either formal or informal; with structured or unstructured questions; and conducted individually or collectively (McGinn, 2010). This study used semi-structured questions, which were in-depth and audio recorded. In a semistructured interview, the interviewer uses a number of key questions as a guide to conducting interviews. The advantage of semi-structured interviews is the freedom to adjust the questions according to the situation in the field, for example, it can emphasize the questions that are considered most important for certain participants. A weakness of semi-structured interviews is that the method takes a lot of time and careful communication skills to obtain good quality interview material (Becker \& Bryman, 2005).

In the beginning, the key participants were recruited through email or by phone, they then recommended other participants. The final number of participants was 15, which included government officials, academics, labour researchers, trade unions activists, NGOs workers, and employers. Most of them had experience in their field for more than five years. Labour issues in Indonesia are sensitive, and to protect participants' names do not appear in this thesis. However, their profession, organisation and workplace are mentioned. Some participants were given pseudonyms. The interviewer could not secure any participants from APINDO, which is an important employers' organisation in industrial relations, because the researcher could not make any contact with them.

Other problems, the researchers was difficult to obtain the official permission letter from the DKI government, because of the transition period of the governor. Also, the permission letter from the Ministry of Internal Affairs need a long time to be taken because the government officers had to attend events out of the city. A permission letter could normally be issued within a day, but the interviewer took approximately a month to receive it. 
Interviews were carried out between the end of June and the end of July 2017. A limitation of the data collection at this time stemmed from the inability to directly observe wage council to set the minimum wage, which occurs between August-October every year. The interviews were conducted in several places around Jakarta and surrounding cities that were agreed upon by the interviewer and the participants.

The important points were noted during the interview to make it easier to categorize the transcript results under key themes. The results of the interviews could not be directly transcribed because of the limited time available to do the interviews. Upon completion of each interview, the handwritten notes were directly typed and filed to avoid any loss of data and to review the interview results without any unnecessary delay.

After the transcription process, some unclear statements were confirmed with the participants. Some key quotations were then translated into English.

\subsection{Analysis}

This study used thematic analysis. Braun and Clarke (2006) state that this method is used for identifying, analysing, organising, describing, and reporting themes found within a data set. This method is used to interpret various studies (Boyatzis as cited in Braun \& Clarke, 2006). Two advantages of this analysis are that it can be modified for research that involves detailed or complex data (Braun \& Clarke, 2006; King, 2004); and that it can be used to examine different participants' perspectives, underline similarities and differences, and generate unanticipated insight (Clarke \& King as cited in Nowell et al., 2017, p. 2). A theme is the key data that relates to the research questions. It illustrates a group of patterned responses or a group of meaning within the dataset (Braun \& Clarke, 2006). Thus, themes can be arranged before and after the fieldwork.

There are two ways to identify research themes: inductive and deductive. The deductive process means themes are derived from theoretical frameworks or research questions. This usually occurs before the fieldwork. The inductive process derives themes from the collected data (Braun \& Clarke, 2006). This study used both inductive and deductive processes to set up the themes and subthemes derived from the research questions.

In this research, themes and sub-themes were determined manually and compared and contrasted. This approach is "based on the idea that themes represent the ways in which text is either similar or different from each other" (Ryan \& Bernards, 2005, p. 4). After transcription, all 
results were read several times and categorised into existing themes prior to data collection. At this stage new themes and sub-themes that had arisen from the interviews were also included, such as "the international employers' organisation" that did not appear in the previous set of themes. The list of themes was then layered with the selected events chronologically. This was to ensure all themes met the important events that had been previously selected, such as the enacted date of each law and political events. The final report was constructed around these themes and sub-themes. 


\section{Chapter 3:}

\section{A Brief History of the State, Workers and Employers in Indonesia}

This chapter provides an overview of the relationship between the structures of the Indonesian state and the agency of those active within it. The dialectical process between structure and agency also affects contemporary workers' struggles for minimum wage increases. Drawing on world-systems analysis, this chapter also describes how the incorporation of Indonesia into the modern international division of labour occurred, which can be traced back to the Dutch ethical policy of the 1900s.

\subsection{Foundation of the state}

\subsubsection{Impact of Dutch ethical policy}

Anderson (2006) believed that the concept of Indonesia emerged in the 1900s. Before that year, resistance against Dutch colonists was regional rather than aiming for national liberation. Anderson also notes that the contemporary regions of Indonesia were mostly conquered by the Dutch in the period 1850 to 1910 . During this time the Dutch began to establish a single centralised power base over what had previously been separate self-governing kingdoms.

Under these self-governing kingdoms' society could be categorized into two groups. One that preserved its original indigenous traditions. The other was as a group that had been culturally influenced by Hinduism, Buddhism, and Islam, as well as European traditions (Kroef, 1956). For example, Buddhism and Hinduism influenced the stratification of communities based around castes, such as Brahmin (priests and teachers), Kshatriya (warriors and rulers), Vaishya (farmers, traders, and merchants), and Shudra (workers). Similarly, the teachings of Islam affected the emergence of kiajihs and ulamas (scholars of the writ) that had an essential role in the community. However, these two groups lived and mixed in Indonesia without clear boundaries (Kroef, 1956).

In drawing previously separate territories into a single state, the Dutch colonial project simultaneously created new regional boundaries that divided areas of the archipelago that had once been ruled together. In addition to the change in the geographic area, colonialism caused significant changes to traditional forms of social, cultural and political organisation, and it created new social 
classes in the 19th Century. The Dutch colonial project emphasised the racial contours of society as a foundation of the new social classes. This project established the Dutch and other Europeans as the new social elite. These highest strata of society also included a Eurasian element. In contrast, Indonesians occupied the lower tiers of society, except for the nobility who had an affiliation with the Dutch colonial administration. Foreign minorities, including Chinese, Arabians and Indians occupied an intermediate stratum, and mostly dominated the retail sector and credit operations (Kroef, 1956).

Recognising the disparity between social classes in the colony, some groups, such as liberals and socialists in the Netherlands, urged their government to pay more attention to the welfare of the colonies. That initial idea came from C.T. Van Deventer, a solicitor on the island of Java. In 1898, he wrote an article entitled The Debt of Honour, in which he reported on how the Dutch could prosper from colonisation. Meanwhile, the colonies became poor and displaced. He put forward ideas about how to improve the prosperity of the colonies. These ideas eventually became demands levelled at the Dutch parliament.

In 1901, the Dutch government began to implement an ethical policy (Joedadibrata, 2012, p. 8). This policy can be viewed as the original form of the welfare programme in the East Indies ${ }^{1}$. The ethical policy consisted of irrigation, transmigration and education programmes (Joedadibrata, 2012). These changes were justified on the basis that they would bring "progress and prosperity" to the "natives" (Vickers, 2005, p. 16-25; Joedadibrata, 2012, p. 8). The colonial government, however, had a hidden agenda. They aimed to profit from the colonised areas (Vickers, 2005, p. 1625). For instance, irrigation systems were introduced to increase food stocks not for natives, but rather for the Dutch and for exportation. People from the island of Java were forced to migrate to other islands in the archipelago to open up land for agriculture to further increase food production. They were forced to work on the Dutch-owned plantations for minimal wages. The wages received were only enough to buy poor quality meals (Tjandra, 2016, p. 31-32). The purpose of education under colonialism was chiefly to provide the government with literate subjects to fill administrative positions. Indonesian people who could afford school were the highest placed groups in what was the lowest social tier in the East Indies society.

An unintended outcome of this education effort was the creation of a cadre of Indonesian intellectuals who pursued higher education in both Java and the Netherlands. It was from the ranks of these intellectuals that the leaders of the Indonesian independence movement emerged. This period, 1910-1920, was a dynamic time for the political and trade union movements in Indonesia

\footnotetext{
${ }^{1}$ The East Indies will only be used in this section to refer to the Dutch colonial areas.
} 
(Ingleson, 2014). The European unions in the East Indies were affected by the ethical policy. They began to establish relationships with the indigenous workers. The indigenous trade unions also grew, following the model of the European trade unions (Cahyono, 2003). These trade unions and political organisations were led by students and educated workers who had been working in Dutch government offices or in the factories. According to Ingleson (2014) some workers' leaders graduated from the Netherlands. But, in 1930, most of the leaders graduated from higher education institutions in the East Indies. They used their analytical abilities in the production of trade unions' magazines and newspapers.

These educated people organize themselves and the workers into political organisations and trade unions, such as Sarikat Islam (SI, Moslem Association); Indische Sociaal-Democratische Party (ISDP, Social Democratic Party of Hindia); and Persatuan Vakbond Pegawai Negeri (PVPN, Association of Civil Service Unions). The leaders of the trade unions were mostly members of political organisations (Ingleson, 2014). Therefore political issues and nationalism also spread among the workers. The idea of Indonesia as a nation was awakened in this time.

\subsubsection{Emergence of social justice concepts}

The doctrine that Indonesia is Negara Pancasila (a Pancasila State) is firmly embedded in Indonesians mind. Since the New Order, Indonesia citizens believe Indonesia is not a capitalist nor socialist state, but is rather based on Pancasila ideology.

Sukarno -one of the most influence leader in the independence movement and then became the first president of Indonesia- initially floated the concept of Pancasila at a preparatory meeting of Badan Penyelidik Usaha Persiapan Kemerdekaan Indonesia (BPUPKI, The Investigating Committee for Preparatory Works for Independence) (Herlambang, 2017). After the proclamation of Indonesian independence on 17 August 1945, Pancasila became the official philosophical foundation of the Indonesian State. At this time, Indonesian leaders were building the concept of social justice to be embodied in Pancasila (Tavip, 2013).

Sukarno interpreted Pancasila to refer to the political concessions underlying the establishment of the state. Bourchier (2015) noted that the first concept of Pancasila raised by Sukarno seems similar to the Three People's Principles (San-Min-Chu-I) of Kuomintang; Nationalism, Democracy and Socialism. This similarity is also seen in the political concept of Nationalism, Religion and Communism used by Sukarno in the period of Guided Democracy, which will be discussed in the section 3.2.2. 
In the New Order, Suharto asserted Pancasila as an official ideology, not only of the state but also of all civil organisations and individual. It means Pancasila, in the form of government interpretation, become guidance for the citizen's relationship (Weatherbee, 1985). Since Suharto, the Indonesian government has continued to use Pancasila to assess its citizens' activities (Weatherbee, 1985; Ricklefs, 2008). Suharto separated Pancasila from the conception of socialism and communism, which had both been banned since 1965. Suharto's version of Pancasila was included as part of the school curriculum. Pancasila also became a compulsory course, the "Guide to the Realisation and Implementation of Pancasila", in government institutions, schools and higher education. Through that process, Suharto shaped what has been referred to as a dutiful society and built a harmonious "family state" (Bourchier, 2015). Pancasila as a tool to promote a harmonious system also applied to industrial relations that will be discussed in section 3.2.3. Since the New Order, the meaning of social justice in Pancasila is lost because of its changing function.

\subsection{Trade unions from Dutch colonization to the New Order}

\subsubsection{Dutch colonization}

As mentioned in section 3.1.1, during the colonial period, the workers and political organisations played a role in the awakening the Indonesian consciousness to organize themselves into trade unions and political organisations. In that time, trade unions were strongly influenced by political ideologies, namely nationalism, Islam and socialism (Tedjasukmana, 1959). These ideologies influenced each other through their leaders. For example, in the Vereniging van Spoor en Traam Personnel (VSTP, Trade Union of Rail-road and Tram Workers) (Tedjasukmana, 1959). One of its leaders, Semaun, was originally a student who boarded in the house of H.O.S Cokroaminoto. Cokroaminoto was the leader of the Sarekat Islam (Moslem Association). At the same time, Semaun also became Sneevliet's friend. Sneevliet was a member of a communist group (Triyana \& Isnaeni, 2017). The two ideologies, Islam — as in Indonesia Islam also become an Ideology of social and political organisation-and socialism, influenced Semaun. The VSTP were more militant and aggressive than under the leadership of Semaun and Sneevliet in 1913 (Tedjasukmana, 1959). In 1919, another member of Sarekat Islam established the first trade union federation in Indonesia, Persatuan Pergerakan Kaum Buruh (PPKB, the Union of Labour Movement). VSTP, then became a member of the Union of Labour Movement (Tedjasukmana, 1959).

At this time, the trade unions also struggled economically. Both European and Indonesian 
trade unions urged the Dutch government to provide protection for wages. The pressure was conveyed through the Volksraad (People's Council) that was established by the Dutch government. In the Volksraad, both European and Indonesian members cooperated to improve the social protection law. In 1919, a worker committee was formed which served to oversee workers' conditions and certain issues. The workers' commission encouraged a legal minimum wage for Indonesians. Even though, the majority of commission members rejected that thee minimum family wage should consider the costs incurred by having a spouse and children. The majority of the commission proposed a different amount of minimum wage for men, women and children. Men's minimum wage was determined on the basis of local living costs; while women accounted for about 80 per cent of men's wages; boys aged 12-16 accounted for 60 per cent; and children under 12 accounted for 40 per cent. The wage rate was based on the length of working day being 10 hours for 6 consecutive days. The small number of committee members, who were Indonesian, rejected the majority proposal. They calculated that the amount earned by a single worker would not be enough for the whole family. At the time the minimum wage for a single worker was 50 cents per day. In comparison, the needs of a prisoner in jail were 47 cents per day (Ingleson, 2014).

While a minority group of the workers' commission urged the government to increase the minimum wage, the intensity of the trade union struggle reached a peak. Thus, the Dutch government decided to exile the union leaders to Boven Digul Island. But union resistance did not subside until the Japanese occupation, which prevented the operation of any organisation established in Indonesia. They only authorized some organisations that had been founded by the Japanese government such as Seinendan (youth corps) and Funjikai (women's corps). Under the Japanese government, the activities of trade unions were silent. Most of the trade unions moved their activities underground to avoid arrest from the Japanese military (Tedjasukmana, 1959).

Workers' struggle emerged again at the time of Indonesian independence. For example, when they gathered in solidarity with the Waterfront unions in Australia. The workers who worked on the ships went on strike, hampering the movement of Dutch ships. This effort successfully prevented Dutch troops from returning to Indonesia (Heryanto, 2016; Male, 1965). Most of the workers who called for solidarity were exiles from parts of Indonesia, such as Boven Digul. When the Dutch had surrendered to the Japanese they taken some exiles with them to Australia as refugees. These exiles then worked in the harbour. Even though, they lived far from their country, these trade union leaders still managed to organize among themselves. Tedjasukmana (1959) argued that 
The Indonesian trade unions are an image of the Revolution. The structure of the unions are designed in such a way that they can easily function as tools or vehicles of the revolution. These structures bear the marks of simplicity, flexibility, mobility, and the other prerequisites of a fighting organisations (p. 43).

In the period before the proclamation of Indonesia independence, trade unions had a form that enabled them to adapt to the change. For example, trade unions were able to affiliate with various political organisations to fight for Indonesian independence. In a repressive situation, such as being under Japanese occupation, trade unions adopted some strategies to keep their organisations running.

\subsubsection{The Old Order}

Following the proclamation of Indonesian independence in 1945, the Sukarno government can be viewed as passing through two separate stages: the first between 1945-1958; and the second between 1959-1966. The second period was called "guided democracy". During the first period, social justice principles were the primary guidelines for leading the country.

The manifestations of these concepts were seen from the various government regulations, particularly in terms of industrial relationship issues, especially of how to solve industrial conflict between workers and employers. The Sukarno regime ratified three International Labor Organisation (ILO) conventions after Indonesia became a member of the ILO in 1950. On 12 June 1950, Indonesia ratified the ILO Convention No. 29 on Forced Labour 1930. Then, on 15 July 1957, Indonesia ratified the ILO Convention No. 98 of the Right to Organize and Collective Bargaining 1949. Lastly, on 11 August 1958, the ILO Convention No. 100 of the Equal Remuneration Convention 1951, was ratified by the Indonesian government (ILO, n.d.).

During this period, Indonesia enacted seven labour laws, such as the Labour Law No. 23 of the Labour Inspection 1948, and the Labour Law No. 22 of 1957 concerned Industrial Relation Dispute Settlements. These regulations created a chance for the labour-force to establish their unions, and encourage collective bargaining. The trade union movement had a relative degree of freedom in this era (Rupidara \& McGraw, 2009). As a consequence, in 1955, there were approximately 1,501 national, regional and local unions (Rupidara \& McGraw, 2009; Hadiz 1997). Derived from the previous tradition, the Sukarno government also allowed various ideologies in 
trade unions. Before 1965, a survey result showed that the unionists had various ideologies, such as Anarcho-syndicalism; Catholic corporatism; and "early versions of Pancasila" (Ford, 2000, p. 5). Tjandra (2016) noted that the Sukarno government tended to empower unions. There was an effort to balance the power of the employers and to develop a good industrial relationship. Consequently, the workers had a stronger legal position when dealing with their employers. The unions could directly negotiate with their employer. Further to this, employers could not terminate workers' contracts without the government's approval (Tjandra, 2016). The vision of state independence, that was reflected in Sukarno's encouragement for his people's self-reliance can be seen in the economic policies that do not curb the freedom of workers. Although Indonesia having had some debt with the International Monetary Fund (IMF) and the World Bank since 1950.

The Sukarno government was also concerned with minimum wage policy. Ingleson (2014) wrote that the first labour regulation after the proclamation of Indonesian independence was the minimum wage policy. In 1956, the government decided that wages should be based on the minimum physical needs for a day and a comparison between the highest and lowest wage rates in companies or divisions (Masduki, n.d). In this formulation, the setting of the minimum wage would involve a nutritionist team to ensure the calculation fulfilled the minimum physical needs.

Similarly within the Dutch period, trade unions also fought for their interests through political activities. At this time, there were two opinions about the involvement of workers in political parties during the Sukarno period. First, was the opinion that the political parties used trade unions as a way to raise the number of members and voters. The second stated that some unions joined political parties as a strategy to influence government policies. Some experts tended to argue that the unions were more directed by political party interests than socio-economic welfare goals (La Botz, 200; Rupidara \& McGraw, 2009; Tjandra, 2016).

The second period of the Sukarno period, that of "guided democracy", constituted the head of the state as the centre of decision- making. La Bots (2001) called this political system a kind of dictatorship. At this time, Sukarno developed a new ideology called Nasionalis, Islam, Komunis (NASAKOM, Nationalism, Religion and Communism). Through this ideology, he put himself as arbiter between the Army, the Moslem party, and the Communist party. One of the triggers of the emergence of NASAKOM was the election result of 1955, which established the positions of four significant parties in Indonesia: Partai Nasional Indonesia (PNI, National Indonesian Party), Majelis Syuro Indonesia (Masjumi, Muslim Federation), Nahdatul Ulama (NU, Muslim Schoolmen's Association) and Partai Komunis Indonesia (PKI, Indonesian Communist Party). 
Respectively the vote results were 8.4 million, 7.9 million, 6.96 million and 6.17 million. The Indonesian Communist Party, which at that time had approximately 3 million members, strongly supported and influenced Sukarno's policies (Rabasa \& Haseman, 2002). Therefore, some political parties believed that Sukarno's political concept benefited the trade unions under Partai Komunis Indonesia (PKI, Indonesian Communist Party), such as Sentral Organisasi Buruh Seluruh Indonesia (SOBSI, All-Indonesian Central Labours Organisations). On the other hand, the Army urged that it be able to enter the social and political domain in Indonesia

At this time Indonesia had cut ties with international financial institutions and bilateral loans. In 1963, when Sukarno undertook non-aligned politics, Indonesia received assistance from the Soviet Union. This prompted the United States (US) to openly ask Indonesia to enter their political block. The IMF played a role in connecting US interests with those of Indonesia at this time. They offered loans with restricted conditions. Negotiations process were between Indonesia, the US, the IMF and the OECD (the Organisation for Economic Co-operation and Development) countries. However, the agreement was cancelled because the British proclaimed the independence of the Malaysian Federation. Sukarno saw this as a threat to the stability of non-aligned countries. After leaving the United Nations (UN), Indonesia also decided to leave the IMF and the World Bank in 1965. As a result, Sukarno nationalized some British-owned companies that had been operating in Indonesia (Toussaint, 2014).

The initial idea of nationalisation came from Indonesian workers (Tjandra, 2016). In December 1957, Indonesia was fighting for West Irian (West Papuan) independence from the Netherlands. To pressure the Netherlands, the Government called for unions to strike for 24 hours against all Dutch companies (Bartlett, 1986, cited in Subangun, Berdikari Online, 2017). The next day, workers began to strike at Dutch-owned factories. On 6 December 1957, workers led by the Sentral Serikat Buruh Seluruh Indonesia (SOBSI, All Indonesian Trade Unions Centre) and Kesatuan Buruh Kebangsaan Indonesia (KBKI, the Indonesian National Workers Union) began to take over several Dutch-owned companies. The first was the Office of Koninklijke Paketvaart Maatschappij (KPM, Dutch-owned shipping company). The second was Des Indes Hotel in Jakarta. This occupation action was followed by Serikat Buruh Bank Seluruh Indonesia (SBBSI, the All Indonesian Bank Workers Union), which sought to occupy and control Dutch-owned banks in Jakarta (Subangun, Berdikari Online, 2017).

The Army then intercepted the success of the workers to control the factories. The Ministry of Justice ordered the transfer of management of the company controlled by the workers to the 
Army. Military faction, led by General A.H. Nasution, had proposed The Middle Way doctrine. This doctrine stated that the military should be involved in politics and society (La Bots, 2001). On 10 December 1957 simultaneously with the war emergency situation, Kepala Staf Angkatan Darat (KASAD, the Army Chief of Staff) ordered the military authorities to take over the management of Dutch companies in their respective regions. The military, which had been given the power to engage in politics and society, established a corporate board in every nationalised company. This marked the beginning of military business, which then affected the control of the Indonesian economy in the New Order era. Meanwhile, the Indonesian Parliament enacted Government Regulation No. 23 of 1958, which stated that the Dutch companies that had been nationalised belonged to the Indonesian government. Those two factors were the turning point of the nationalised movement by the workers. The workers who initiated the nationalisation movement should hand over all the companies to Indonesian government and the Army.

The situation was increasingly unfavourable for workers. The government, also, enacted the Regulation of the Supreme War Leader No. 4 of 1960, which prevented strikes and/or lockouts in factories, state agencies, and other vital institutions. However, the nationalisation had made the trade unions' movement weak (McVey, 2008). This could be seen from the number of workers strikes from 1950 to 1966 which began to decline, as seen in table 3.1

Table 3.1 Workers strikes 1950-1966

\begin{tabular}{|r|r|r|}
\hline Year & Number & Workers Involved \\
\hline 1950 & 184 & 491,000 \\
\hline 1951 & 541 & 319,000 \\
\hline 1952 & 349 & 133,000 \\
\hline 1953 & 280 & 420,000 \\
\hline 1954 & 347 & 158,000 \\
\hline 1955 & 469 & 283,872 \\
\hline 1956 & 505 & 340,203 \\
\hline 1957 & 151 & $1,092,107$ \\
\hline 1958 & 55 & 13,578 \\
\hline 1959 & 70 & 26,626 \\
\hline 1960 & 64 & 14,577 \\
\hline 1961 & 86 & 63,111 \\
\hline 1962 & 34 & 12,225 \\
\hline 1963 & 54 & 25,080 \\
\hline 1964 & 21 & 15,641 \\
\hline 1965 & 4 & 470 \\
\hline 1966 & 2 & 24 \\
\hline
\end{tabular}

Note. Strikes between 1950-1954 adapted from Kings (1982) as cited in Hadiz (1997).

Strikes between 1955-1966 adapted from the ILO $(1964,1974,1995)$ as cited in Gall (1998). 
The imperialist countries were deeply concerned about the nationalisation of their companies in Indonesia. The US, the UK and the Netherlands, which in world-systems analysis are core countries, had companies operating in Indonesia. They saw Sukarno and his non-aligned foreign politics as a threat to their global hegemony. Therefore, these countries were looking for ways to keep their investments in Indonesia, and decided to fund two military rebellions against Indonesia. The first was in 1958 when the US supplied weapons to the resistance of Pemerintah Revolusioner Republik Indonesia (PRRI, the Revolutionary Government of Republic of Indonesia) in Sumatra, and Pemberontakan Semesta (Permesta, the universe's struggle) in the Eastern part of Indonesia (Subangun, Berdikari Online, 2017). Permesta also had support from Japan, Taiwan and the Philippines, which were anti-communist (Raditya, Tirto, 2017). However, the government of Indonesia successfully thwarted the rebellion.

In 1965, the American government supported an Indonesian military group to kill seven military generals. The killing was later blamed on the Indonesian Communist Party. General Suharto, an Army member, became a hero who led his troops to find the bodies of the seven dead generals. The killing led to a widespread massacre of communists in Indonesia, mostly by paramilitary members. The International People's Tribunal held in The Hague, The Netherlands, in November 2015 estimates that about one million dead were accused of being the leaders, members and sympathizers of the Indonesian Communist Party.

This massacre was an outcome of a political crisis and economic crisis. These crises were triggered by conflict between PKI, army leaders, and the Islamic political party and its mass organisations. The economic crisis was marked by hyperinflation and it escalated tensions in the political atmosphere. It provoked people to hold a mass strike against Sukarno. Numerous studies highlighted the involvement of the United States in supporting and emboldening the army faction under Suharto's leadership. This is related to the context of the cold war between the United States and its allies against the Communist Block that was led by the Soviet Union and China (Mushed \& Tadjoeddin, 2015). The hyperinflation opened opportunities for Sukarno's opponents to gain support from the public. Student demonstrations demanded a drop in prices (Beerkens, n.d.). Meanwhile, Buruh Tani Indonesia (BTI, Indonesian Peasants Workers) had a land reform programme that threatened mostly Muslim landlords, especially among Nahdatul Ulama (NU, Muslim Schoolmen's Associaton) (McGregor, 2009) and Masyumi.

On 11 March 1966, Suharto declared that he received Surat Perintah Sebelas Maret (Supersemar, the warrant Eleven March) from Sukarno. Suharto claimed that this Letter contained a 
mandate stating that Suharto could take actions to secure the situation. Through this letter, Suharto unofficially began to rule Indonesia, while Sukarno de facto lost his power.

The coup d'etat of 30 September 1965, successfully restored foreign investment in Indonesia. On 21 February 1967, the crisis pushed Indonesia to return as a member of the IMF. The integration of Indonesia into the International division of labour followed from this. Indonesia went back under the hegemony of the core countries. Sukarno had, previously, enacted Law No. 1 of 1967 on Foreign Investment on 10 January 1967. This law allowed foreign capital opportunities to invest in Indonesia with low taxes. In April 1967, Freeport Sulphur of Delaware became the first foreign company to start new operations in Indonesia, mining gold on the Tembagapura, Papua.

In March 1967, the Indonesian Army, led by Suharto, urged Majelis Permusyawaratan Rakyat Sementara (MPRS, the People's Consultative Assembly) to remove Sukarno from his position as Indonesian President. On that date Suharto officially, replaced Sukarno as President of the Republic of Indonesia. Since this time the trade union movement in Indonesia has been in decline.

\subsubsection{The New Order}

As mentioned in the previous section, the New Order began in 1966 after Suharto, with the support of the CIA, repressed the labour movement to enable foreign capitalist investment in Indonesia (Simpson, 2017). The change began with the massacre of 800,000 people (Hadiz, 2006). Most victims were accused of being members of the Indonesian Communist Party and other organisations that were associated with them, such as SOBSI (Sentral Serikat Buruh Seluruh, All-Indonesia Central Labor Organisation); BTI (Barisan Tani Indonesia, Peasat Front of Indonesia); and GERWANI (Gerakan Wanita Indonesia, Indonesian Women Movement). According to Robison (1986) "the expansion of capitalism after the mid-1960s was possible only after the political victory of the military over the PKI (Partai Komunis Indonesia or Indonesia Communist Party) and the Sukarno regime" (as cited in Farid, 2005, p. 5). These mass killings were aimed to secure the capital of certain social classes from the threat of landless workers and urban workers (Robison, 1986, as cited in Farid, 2005).

Suharto then established some organisations and parties which supported his interests and repressed other organisations that would become hindrances in the future, such as liberal reformist middle classes and trade unions (Robison \& Hadiz, 2004). He created one trade union, named Federasi Buruh Seluruh Indonesia (FBSI, All-Indonesia Labour Federation), and three political 
parties controlled by the Indonesian government: Partai Persatuan Pembangunan (PPP, United Development Party); Golongan Karya (GOLKAR, the Party of the Service Society); and Partai Demokrasi Indonesia (PDIP, Indonesian Democratic Party) (Robison, 2009). However, this process created "a new type of third world capitalist economy and state characterized by the high rate of economic growth, rapid industrialization, the development of the powerful national bourgeoisie and a strong authoritarian regime" (Higgots \& Robison, 2014, p. 60-61).

To restrain the workers' turmoil, the New Order government created the framework of Hubungan Industrial Pancasila (HIP, Pancasila Industrial Relations). Its formal role was to facilitate a relationship between workers, employers and governments based on the values of Pancasila and the 1945 Constitution, which was "in accordance with the National characters and National Culture" (Hadiz, 1997, p. 88). This was also to confront the liberal and Marxist concepts that were associated with Western doctrine (Hadiz, 1997). At the beginning of the New Order, between 1967-1973, the ideology used by the New Order tended to be an inclusion mechanism. This meant the relationships between workers, employers and the state were more cooperative than forcing the achievement of industrial relations objectives.

After the fall of international oil prices in 1980, Indonesia changed the industrial strategy to a labour-intensive one, which worked for light manufactured goods or low technology industries (Hadiz, 1997). The shifting of labour-intensive manufacturing industries from developed to developing countries was triggered by higher production costs in developed countries, including high wages and raw materials. Moving factories into the developing countries with sufficient natural resources to support the production process allowed costs to be cut. Labour-intensive industry also required low minimum wages and an obedient workforce. Therefore, third world countries, such as Indonesia, had an interest in keeping its place in the International Division of labour (Hadiz, 1997).

Further, the need to create a friendly industrial environment had caused the New Order government to change the concept of Industrial Relations Pancasila to be more exclusionary. The New Order government introduced a number of terms, such as family principles, traditional values of mutual benefit and deliberation to reach a consensus in both bipartite and tripartite relationships. From 1985-1998, the rhetoric of Pancasila Industrial Relations became more Unitarian, which meant creating a family-type unit within a company that had a common interest and purpose (Ford, 1999). Pancasila industrial relations directly suppressed the interests of workers in industrial relations, because the problem between the workers and employers could be resolved by dialogue as 
a "family". Someone who ignored these principles would be categorized as a threat to the Pancasila, which also meant they were seen as a threat to the government. Based on these objectives, the Suharto regime established Komando Pemulihan Keamanan dan Ketertiban (KOPKAMTIB, Command for Restoration of Order and Security) in the early emergence of the New Order. It was a supra-national security agency intertwined with the structure of the military (Hadiz, 1997). In 1988, this unit was changed to Badan Koordinasi Bantuan Pemantapan Stabilitas Nasional (BAKORSTRANAS, National Coordinating Body for Stabilization Assistance Coordination). The framework for Pancasila industrial relations was implemented in the formal, legal labour institutions for conflict resolution purposes such as the Regional Dispute Settlement Committee (P4D) and the Central Labour Dispute Settlement Committee (P4P).

The worker framework produced by Suharto, succeeded in reducing workers' strike action. As a result, the number of workers' strikes increased between 1965 and 1980. It can be seen in table 3.2 .

Table 3.2 Workers' strikes 1967-2000

\begin{tabular}{|r|r|r|}
\hline Year & Number & Workers involved \\
\hline 1967 & 6 & 1,172 \\
\hline 1968 & 2 & 575 \\
\hline 1969 & 0 & 0 \\
\hline 1970 & 0 & 0 \\
\hline 1971 & 1 & 27 \\
\hline 1972 & 1 & 70 \\
\hline 1973 & 3 & 624 \\
\hline 1974 & 6 & 672 \\
\hline 1975 & 13 & 5,636 \\
\hline 1976 & 6 & 1,420 \\
\hline 1977 & 32 & 10,209 \\
\hline 1978 & 20 & 3,772 \\
\hline 1979 & 72 & 18,940 \\
\hline 1980 & 198 & 21,661 \\
\hline 1981 & 125 & 29,525 \\
\hline 1982 & 224 & 55,562 \\
\hline 1983 & 104 & 26,300 \\
\hline 1984 & 29 & 2,773 \\
\hline 1985 & 78 & 21,148 \\
\hline 1986 & 73 & 15,778 \\
\hline 1987 & 37 & 14,005 \\
\hline 1988 & 39 & 15,514 \\
\hline 1989 & 19 & 5,467 \\
\hline 1990 & 61 & 31,324 \\
\hline 1991 & 130 & 62,624 \\
\hline
\end{tabular}




\begin{tabular}{|r|r|r|}
\hline 1992 & 228 & 228,437 \\
\hline 1993 & 312 & 97,807 \\
\hline 1994 & 1,130 & $\mathrm{n} / \mathrm{a}$ \\
\hline 1995 & 276 & $\mathrm{n} / \mathrm{a}$ \\
\hline 1996 & 350 & $\mathrm{n} / \mathrm{a}$ \\
\hline 1997 & 161 & $\mathrm{n} / \mathrm{a}$ \\
\hline 1998 & 234 & $\mathrm{n} / \mathrm{a}$ \\
\hline 1999 & 125 & $\mathrm{n} / \mathrm{a}$ \\
\hline 2000 & 174 & $\mathrm{n} / \mathrm{a}$ \\
\hline
\end{tabular}

Note. Data for strikes between 1967-1994 were adapted from the ILO $(1964,1974,1995)$ as cited in Gal $(1998)$. Data for strikes between 1995-2000 were adapted from the Ministry of Manpower and Transmigration and LPPPES (2000) as cited in Surbakti (2005).

The number of workers' strikes in the 1980s marked the emergence of the independent trade unions in Indonesia, non-Serikat Pekerja Seluruh Indonesia (non-SPSI, non-All Indonesian Workers' Trade Unions), which were formerly operated by the FPBSI (Federasi Buruh Seluruh Indonesia, All-Indonesia Labour Federation) (Gall, 1998). In general, they demanded a minimum wage rise and freedom of association, particularly at the end of the 1990s (Surbakti, 2005). It was started with the establishing of the Merdeka Setia Kawan (SBMSK, Solidarity Free Trade Union). Followed by the establishment of Serikat Buruh Seluruh Indonesia (SBSI, the Indonesia Prosperity Trade Union) led by Muchtar Pakpahan. At this time, various labour-based Non-Government Organisations (NGOs) were also established, such as Saluran Informasi Perburuhan dan Bimbingan Hukum (SISBIKUM, Information Channel and Legal Assistance); Institut Sosial (IS, Social Institute); Yayasan Komunikasi Massa (YAKOMA, Mass Communication Foundation); and Yayasan Lembaga Bantuan Hukum (YLBHI, the Indonesian Legal Aid Institute). One of the YLBHI's staff Teten Masduki had an important role to play in the Forum Solidaritas Buruh (FORSOL, Labour Solidarity Forum), which aims to collaborate among labor-based NGOs (Hadiz, 1997). Around 1990, Pusat Perjuangan Buruh Indonesia (PPBI, the Centre for Indonesian Working Class Struggle) was established by a number of activists including student activists. The PPBI claimed to be part of a democratic struggle. Their aim was different to other workers organisations that claimed to engage in socio-economic struggles or NGOs that claimed to be a part of a social movement. According to Torquist (2011), this democratic movement was established to fight for real democracy. In other words, the democratic movement perceived the current democracy to be fake. In Indonesia, the democratic movement was also divided into two groups: those with a unifying ideology; and those that believed that ideology was unnecessary. The second group offered the concept of an alternative development path for society.

In terms of the minimum wage, Suharto changed some policies. The New Order 
strengthened its position on the minimum wage policy-making process, which involved disputes between workers and employers. The New Order established the National Wage Council in 1970, after they enacted Presidential Decree No. 85 of 1969 on the National Wage Council. Then, the Regional Wage Council was established by the governor or head of each district. Wage council, both in national and regional forms, consisted of government, industrial, and workers' representatives. Kamar Dagang dan Industri Indonesia (KADIN, Indonesian Chamber of Trade and Industry) appointed the Asosiasi Pengusaha Indonesia (APINDO, Indonesian Employers' Association) to represent the employers on the Wage Council, while the only trade union representative was from Serikat Pekerja Seluruh Indonesia (SPSI, All Indonesian Workers' Unions). Every year they decided the amount of the monthly minimum wage. The calculation of the minimum wage was based on the physical basic needs and a market price survey that was conducted by the National Wage Council. The minimum wage policy was officially applied when the government enacted the Ministry of Manpower Regulation No. Per-05/Men/1989 on the Minimum Wage; that defined the minimum was the lowest main wage and did not include allowances. This regulation was changed to the Ministry of Manpower Regulation No. Per10/Men/1990 regarding the change of the Ministry of Manpower Regulation No. Per- 05/Men/1989. Based on the regulation, the physical basic needs to be consisted of 5 components and 48 items. A component was a group of basic consumer goods. While, an item was a basic consumer good necessary for life, such as a plate of food. For example, the food and drink components consisted of items such 3 meals per day, drinking water and kitchen utensils. The 5 components of the physical basic needs were: food and drink (17 items); fuel, lighting and conditioning (4 items); housing and kitchen utensils (11 items); clothing (10 items); and miscellaneous (6 items).

Between 1967 and 1978, there were not many workers strikes fighting for higher wages. This was despite the minimum wage not being enough to fulfil the basic needs of a human in a month. That situation created a conducive industrial environment for investment (Ford, 2004, p. 24).

In 1994 the biggest demonstration to have occurred during the New Order took place in Medan, North Sumatra. The demonstration was conducted by Serikat Buruh Seluruh Indonesia (SBSI, All Prosperity Trade Unions). Led by Muhktar Pakpahan, the workers strikes lasted for two weeks and involved 10,000 workers (Human Rights Watch, 1994). The workers demanded a minimum wage rise of Rp 3,100 to Rp 7,000. Facing the workers' appeals, the companies avoided meeting with the workers. They secured themselves behind the government apparatus. In that year 
6,942 companies were investigated for wage violations. Then the industrial relations inspectors found 1,187 companies that had committed wage violations to the workers, but only 17 companies were taken to trial (Kumparan, 2017). Unfortunately, the workers' strikes were followed by unexpected racial riots, during which a Chinese businessman was killed. As a result of this strike the SBSI leader Mukhtar Pakpahan, and other members, were arrested. Striking was banned by the Indonesian government in 1995 (Ford 2004, p. 24).

After striking was prohibited, the worker stoppages did not vanish. In November 1995, the workers of Sritex factory in Solo went on strike. On 8 July 1996 about 40,000 workers in Tandes, Surabaya, took part in a strike. As a result of this strike, some trade union activists were arrested and prosecuted. In the same month, there was an attack on the office of the Indonesian Democratic Party of Struggle, which led to some pro-democracy activists being abducted. Strikes simultaneously occurred in many parts of Indonesia until the fall of the New Order in March 1998. The New Order ended when Suharto resigned from the office of President of Republic of Indonesia, after thousands of students and people occupied the parliament building in Jakarta for several weeks. From here to the reformation era, the strength of the workers rose to balance the strength of the employers.

\subsection{Indonesian employers}

The formation of the bourgeoisie among indigenous Indonesians occurred through a series of political-economic processes that began in the Old Order. At the beginning of independence, Indonesia did not have a native capitalist system. Although in 1900 medium-scale traders existed. For example, the traders were incorporated in the Sarekat Dagang Islam (SDI, Islamic Trade Unions) and later changed to Sarekat Islam (SI, Islamic Union). But they did not have any political power to shape an economic system in Indonesia. After independence the Dutch, Europeans, Indians, Chinese-Indonesians and foreign Chinese employers continued to dominate the Indonesian economy (La Bots, 2001). Sukarno intended to change the structure of the predominantly foreign economy and make indigenous employers more sovereign. Sukarno's mission for change was encouraged by the trade union movement, which carried out strikes and occupations of Dutchowned factories. During the Old Order, Sukarno established two main programmes to strengthen the domestic economy. The first was the Program Benteng (Fortress Programme), which aimed to protect the interests of the national bourgeoisie who were unable to compete with foreign and Chinese-Indonesian employers. The second was through the nationalisation of foreign companies. 
The Indonesian government ran the Fortress Programme beginning in 1950, and it was suggested by Sumitro Djoyo Hadikusumo and Djuanda. The Fortress Programme provided credit facilities, permits, and protection for indigenous business people. However, the programme failed in 1956. According to Robison "approximately 70 per cent of the existing plantations in Java and Sumatra returned to foreign employers in 1953. Chinese business people controlled approximately 19 per cent of the plantations in 1952" (Robison 1986, p. 42). A factor that caused the failure was the politico-bureaucrats who granted the business permits to people who had no entrepreneurial skills. The politico-bureaucrats also sold business permits to Chinese employers. They were what came to be called "rent seekers". Similar to the Fortress Programme, the nationalisation of foreign companies did not run well. The military then dominated this process, both in the form of ownership by military organisations and individuals. Robison (1986) stated that one of the reasons the nationalisation programme failed was the absence of the national bourgeoisie. Similarly, La Bots (2001) reaffirmed that many politicians and military leaders involved in commerce and industry, who had often worked with Chinese business people, could not be declared a particular class within a political programme. In the end, these programmes were more beneficial to the state apparatus, which included the military and the politico-bureaucrat. On the other hand, the failure of these programmes increased the patronage mechanism between politico-bureaucrats and their cronies. This mechanism then determined whose businesses would prosper and whose would not. In the end, this relationship became the basis for the emergence of an indigenous capitalist group. This group would later develop into a powerful national and indigenous bourgeoisie. Indeed, the structures formed during this "guided democracy" later influenced the formation of state and capital under the New Order (Ford, 2000).

In contrast, Suharto opened the opportunity for foreign capital to invest in Indonesia. Mushed and Tadjoedin (2015) told that

the new Suharto regime that ruled the country after the mass killing was essentially a continuation of the authoritarian regime, but with a clear Western orientation, openness to foreign capital investing mainly in natural resource exploitation, and more importantly the harnessing of available ethnic Chinese entrepreneurship (p. 23).

During the New Order period, Indonesia's capital ownership structure consisted of state-owned capital, military-owned capital, Chinese capital and indigenous business people (Robison, 1986). The state-owned capital usually operated through state-owned enterprises, which were mostly the 
nationalised companies in the Sukarno era. An example was PT Perkebunan Nusantara, which managed the tea, palm and quinine plantations. The military-owned capital was managed by: military-owned foundations, military personnel, groups, retired military groups and military cooperatives. For example, Kesatuan Organisasi Serbaguna Gotong Royong (KOSGORO, Multi Aid All-Purpose Co-operatives) was a military-owned co-operative. Chinese business people managed a variety of businesses, of which the ASTRA group of William Suryajaya is one example. The majority of indigenous employer groups divided into three categories: 1) the survivors of the Benteng and Guided economy periods; 2) Politico-Bureaucrats of the New Order, who established private business groups; and 3) The new capitalists who emerged under the patronage of the new centre of politico bureaucratic powers (Robison, 1986, p. 329).

Unlike Sukarno who restricted the businesses of people of Chinese descent, Suharto formed alliances with Chinese business people as a way to manage the Indonesian economy. Suharto made this choice pragmatically, as he was of the opinion that business people of Chinese descent would not threaten his position as the leader of Indonesia. For him, these business people were economically stable but politically weak (Mushed \& Tadjoedin, 2016). This opportunity lasted until after Suharto fell, and made a considerable economic gap between the indigenous people and business people of Chinese descent. Their privileged position in the Indonesian economy caused them to become the target of public anger in times of crisis.

The majority of indigenous business people served a political function in Indonesia. First, they ensured the sustainability of the capitalist conglomerate factions that were operating in Indonesia. Second, building relationships between state and capital, related to interest rates, the price of labour power, taxes, access to markets, and competition (Robison, 1986). Based on these interests, the indigenous business people needed an organisation that functioned as a hub for enmployers, and that was Kamar Dagang dan Industri Indonesia (KADIN, the Indonesian Chamber of Trade and Industry). President Suharto enacted the Presidential Decree no. 1 of 1973 in the Indonesian Chamber of Commerce and Industry, and Law no. 1 of 1987 concerning the Indonesian Chambers of Trade and Industry. KADIN has existed since 1968, which was a club of employers, a hub for various business concessions and also an agent of the government. Through this decision KADIN had an increasingly important role for policy making in Indonesia, including minimum wage policy-making. The older employer organisation was Asosiasi Pengusaha Indonesia (APINDO, Indonesia Employers' Association), which was established in 1952. The detail of these two organisations will be discussed in findings chapter four. 


\subsection{Summary}

The workers' struggle demanded the minimum wage had occurred since the Dutch government was established in Indonesia. This struggle was carried out both in the structure provided by the Dutch, the Volksraad (People's Council) and through strikes undertook together with the European trade unions. After Indonesian independence, workers influenced the state both politically and economically. The workers struggled through political parties in which trade unions joined. They also made various demands for welfare improvements.

In brief, state as a structure, and workers and employers as agents have a dynamic relationship. At one time, the government was more supportive of workers' aspirations than to employers. In another time, the government was more in favour of employers' interest than workers' demand. There were some periods when workers were struggling to be more radical, and some periods the trade unions were silent because they were under government pressure. These relationships and its struggling significantly affect the structure and relationships among state, workers and employers that occur in contemporary Indonesia.

The next chapter will discuss the research findings, and discuss how the relationship between workers, employers and the state has developed over recent years. It will also discuss how the struggle between the two interest groups, workers and employers, play out within the power structures that were established as a response to their previous relations. 


\section{Chapter 4: Findings and Discussion}

This chapter will be arranged into two parts; findings and discussion. Finding will be described the result of the fieldwork. The second part is discussion that will be explained the main point of findings using the theoretical frameworks.

\section{Part one: Findings}

The finding section will describe three factors that influence the determination of wage rates in Indonesia. First is state policy. Second is the role of the agents who have interests, such as the workers, the employers, and the government itself. Third is international capital and its associated interests. Jessop (1990) uses the strategic relational approach to assess how the roles of the agencies such as workers, employers and government. Workers and employers as the two leading agencies that are directly concerned with wage rates will maximise the available space, that is provided by regulation, within institutions that allow their involvement and influence. The state, having the role of exercising power not only acts as a provider of space for worker and employers but also as an agent that has interests in the formation of the minimum wage. The factors affecting the state's position on wage rates is global economic conditions and core-countries' interests.

The findings consisted of four sections. First section will address the role of global economic conditions and core-countries' interests in influencing wage policy in Indonesia. Second section will focus on structural aspects and wage policy formulation. Included in this section is the process of the minimum wage determination at the national, district and sectoral levels, and the role of the state in monitoring the implementation of wage policy. Third section addresses the views of the workers on their wage rates and strategies in influencing the setting of wage rates. This section also discusses the leading trade unions and their struggles, including forms of struggle other than involvement in a wage council. Fourth section will address the role of employers within the government and within the competent authorities in the determination of wage levels. This section discusses two of the most influential employers' organisations and how they work in influencing the setting of minimum wage rates. This section discusses the personal involvement of leading employers in politics and government. 


\subsection{The influence of international capital}

The policies of international financial institutions reflect the interests of the core or advanced industry countries. The policies, generally, are in the form of financial aid and recommendations following the funding provided. There are various international financial institutions in the world, including the World Bank and the International Monetary Fund (IMF). At the regional level of Asia, there are also several financial institutions, such as the Asian Development Bank (ADB), and the Asian Infrastructure Investment Bank (AIIB). However, there are three significant institutions influencing the changes of labour policy in Indonesia; the IMF, World Bank and ADB, as described below:

a. The IMF was founded in Bretton Woods in 1945, post-World War II. The original goal was the recovery of war-affected countries. Currently, the number of IMF members is 189 countries. The IMF states that "The decision-making at the IMF is designed to reflect the position of each member of the country in the global economy" (IMF, n.d., Para. 1). Each country has a voting power that is calculated based on a quota formula. "The current quota formula is a weighted average of GDP (weight of 50 percent), openness (30 percent), economic variability (15 percent), and international reserves (5 percent)" (IMF, October 13th, 2017, Para. 2). America, Japan and China are the countries with enormous voting power; 16.52 per cent voting power, 6.15 per cent voting power and 6.05 per cent voting power, respectively. Currently, the IMF aims to secure financial stability in member countries, oversee macroeconomic policies of a country, and also provide loans at lower interest rates. When a country obtains a loan, the IMF will submit a Structural Adjustment Policy (SAP) to be implemented by the recipient country. The SAP is an absolute requirement for the borrowing country. Countries that borrow funds from the IMF will sign an agreement called a Letter of Intent (LoI).

b. The World Bank was established simultaneously with the IMF. The primary goal of the World Bank is to reduce poverty in member countries. The institution also provides loans for economic programmes, technical assistance and finance for infrastructure development. To become a member of the World Bank a country must first become a member of the IMF. The voting system determines the World Bank policy. Currently, eight countries have the most significant voting rights: the USA (15.98 per cent), Japan (6.89 per cent), China (4.45 per cent), Germany (4.04 per cent), France ( 3.78 per cent), the UK (3.78 per cent) and India (2.93 per cent). The World Bank programme is generally in line with the IMF programme. 
c. The ADB. The purpose of $\mathrm{ADB}$ is to provide loans, technical assistance, grants and equity investments to promote social and economic development to its members residing in Asia and the Pacific. Currently, the number of ADB members is 67 countries. There are 27 countries in the nonborrowing shareholder category, and borrowing shareholders total 40 countries. The largest nonborrowing countries are Japan, the US, and Australia with 15.6 per cent, 15.6 per cent and 5.8 per cent of total subscribed capital, respectively. While the largest borrowing state group is China (6.4 per cent of total subscribed capital), India (6.3 per cent) and Indonesia ( 5.4 per cent). The decisionmaking system at ADB also resembles the World Bank. It is based on the most significant voting power that is decided by total subscribed capital (ADB, para. 1).

The countries and international institutions that assist Indonesia established Consultative Group on Indonesia (CGI) on 1992. This forum aimed at gaining an understanding of Indonesian policy (World Bank, para. 1). It was formerly called Inter-Governmental Group on Indonesia (IGGI) that established in 1967. CGI members consist of 30 bilateral and multilateral donors. International agencies, such as the World Bank, the ADB, the Kuwait Fund, the Saudi Fund, the Islamic Development Bank (IDB), the International Fund for Agriculture Development (IFAD), UNICEF, the Nordic Investment Bank, and the European Investment Bank (EIB) are involved. While the countries included in the CGI are Japan, Germany, the US, England, Belgium, France, New Zealand.

The way of the World Bank, IMF and CGI affect labour policy in Indonesia will be explained in the following law and regulations sections. As for workers issues, the ADB provides technical assurances and guidelines for worker relations in Indonesia in the form of research results. For example, the 2005 Economics and Research Department, Development Indicators and Policy Research Division entitled "Road to recovery: Improving the investment climate in Indonesia" reports the mapping of issues that hinder the investment climate in Indonesia. The report found three significant obstacles, such as the issue of governance and institutions. Included in the issues of governance and institutions are the clarity and effectiveness of regulations, the flexibility of the labour market, and the existence of an educated and skilled workforce. The document also reports on The Investment Climate and Productivity Study in 2003 that the ADB and the World Bank, in collaboration with the Coordinating Ministry for Economic Affairs and Badan Pusat Statistik (BPS, Statistic Indonesia). This study found that labour regulations are more than a worker-quality issue related to labour laws that hamper the investment climate including among other things the procedures for dismissal and severance pay, limitations on hiring temporary workers, and rigid 
wage regulations. On numerous occasions, the ADB has expressed its commitment to assisting Asian countries in creating a conducive business climate for foreign direct investment. The commitment is evidenced by the loan programme to countries in Asia to reform the development of policies that support the creation of an investment climate. For the government of Indonesia, one of its programmes is the Development Policy-Support Programmes (DPSP). The ADB designed DPSP related to financial support from some countries and international agencies paralleled with the World Bank and the Government of Japan's aid programme. This programme has six goals. The second goal aims to improve the investment climate. To achieve this goal, the ADB encourages the Indonesian government to reform labour regulations.

These aid programmes are related to the economic crisis experienced by Indonesia due to the impact of the global financial crisis. Since 1997, Indonesia has experienced three times the number of economic crises experienced by other countries; 1997, 2008 and 2013. These crises resulted in industrial relation changes and large-scale termination of employment. One of the biggest crises that affected the regime change was the crisis of 1998. Industries and banking in Indonesia were severely affected by the falling rupiah. At that time as many as 2.5 million workers were laid off. Since the 1997 crisis, Indonesia has signed approximately 24 LoI's in various sectors. Agreement with the IMF still affected labour policy until 2017. It can be seen from the number of industry rules that have been enacted following three labour acts. For the Indonesian government, international policy constitutes the basis for the establishment of minimum wage laws.

In the crisis of 2008, the government issued the Joint Decree of Minister of Manpower and Transmigration, Minister of Industry, Minister of Internal Affairs, and Minister of Trade concerning the Maintaining the Momentum of National Economic Growth in Anticipating the Development of the Global Economy. Under article 3 of the Joint Decree, the provincial governors were not allowed to set minimum wages above the level of national growth. The government revised the Joint Decree after the trade unions demanded this regulation be removed. Overall, wage policy structure in Indonesia tends to adopt international policies.

\subsection{Minimum wage policy}

As explained in chapter three, throughout Indonesia's history, the role of the state to make labour policy has been influenced by three factors, namely workers, employers and international capital. In the Old Order, the state accommodated more workers' interests than international capital. The state partiality was seen through various legislation products that prioritize the interests of the workers. 
The state also accommodated initiatives undertaken by trade unions, such as the nationalisation of foreign companies in Indonesia. In contrast to the New Order, the Indonesian state accommodated the interests of international capital and employers rather than workers. It can be seen from the declining of the trade unions, and the strengthening of the national bourgeoisie in Indonesia.

From the Old to New Order, the state conducted a selective process on workers, employer and international capital forces, that Jessop (1990) called strategic-selectivity. The process was run by the state apparatus and institutions within the state structure. Therefore, Jessop stated that the power struggle between social classes always takes place within a framework of structures created by the state; institutions and mechanisms governed by legislation.

In the minimum wage context, the state issued laws relating to minimum wages. The state also established the Ministry of Manpower to produce various rules about minimum wages. The ministry regulations affected tripartite institutions that contained representatives of employers, workers and the government. The regulations also governed minimum wage decision-making mechanisms. In the implementation of these regulations, the struggle between workers' interests and employers' interests occurred. The process of how workers and employers influenced minimum wage policy can be seen from: the response to labour laws and government regulations regarding wages; workers and employers responding to the definition of the minimum wage; minimum wage formulation; and the minimum wage decision-making process. Based on those processes, this section will be arranged into three sub-sections: laws and regulations, minimum wage definition, and the decision-making process.

\subsubsection{Laws and regulations}

Laws and regulations are the tool of the state shaped by social class struggles and groups' interests (Jessop, 1990). Minimum wage laws and regulations are specifically shaped by workers, employers and International capital.

From the previous section, it was clear that Indonesia adopted some policies from International policy. In the early 2000s, the Indonesian government enacted three labour Laws related to the principles of organizing, negotiating, and acting on minimum wage policy. First is Act No. 21 of 2000 concerning the Trade Unions. Second is Act No. 13 of 2003 regarding Manpower. The last is Act No. 2 of 2004 on the Industrial Relations Dispute Settlement. These three packages of the Labour Law were a consequence of the LoI between the IMF and the Indonesian government. 
This last agreement with the IMF was signed on 18 March 2003, but it consequently affected the conditions of the workers. There were two important points related to labour policy: point 42 and point 43. Point 42 of the LoI highlighted worker relations. Point 43 of the LoI emphasised the minimum wage.

Following the LoI and the World Bank briefing paper for the Consultative Groups on Indonesia (CGI) 2003, Badan Perencanaan Nasional (Bappenas, the National Planning Agency) released a "White Paper: Employment Friendly Labour Policies" underlying the drafting of the three Labour Laws. In 2005-2006, the World Bank-CGI document Briefing Paper of 2005 and the IMF statement for the CGI 2005 became a foundation for the revision plan of the Manpower Law No. 13 of 2003.

Labour legislation and regulations in Indonesia, however, have evolved in accordance with the power changes in Indonesia and also law enforcement from civil society. For example, some Non-Government Organisations (NGOs), labour activists and trade unions proposed a judicial review on some articles in the Ministry of Manpower Act No. 13 of 2003 to the Constitutional Court (Hukum Online, 2016). Here, it can be said that the class struggle has also transformed the law and regulations on the minimum wage. On the other hand, the state performed strategic selectivity based on the context when the demands were made. At times, the state will meet the demands of international capital. At other times, the state will fulfil the demands of the workers or employers.

The transformation of minimum wage policy can be seen through a series of Acts that have been introduced. Before the government implemented Act No. 13 of 2003, the government enacted two regulations on the minimum wage: Ministry of Manpower Regulation No. PER-01/MEN/1999 regarding the minimum wage; and Ministry of Manpower and Transmigration Decree No. KEP226/MEN/2000 that amended the Ministry of Manpower Regulation No. PER-01/MEN/1999 on articles No. 1, 3, 4, 8, 11, 20 and 21. Following this decree, the President of the Republic of Indonesia passed Presidential Decree No. 107 of 2004 concerning the Wage Council. Act No. 13 of 2003 was the result of international capital demand, but it was better at protecting the workers' rights than the previous law. Its content was far better than before, after the state approved some judicial reviews as requested by the workers. Then, this law became a reference for workers to demand changes in other regulations.

In 2005, the Ministry of Manpower and Transmigration enacted Regulation No. PER. 17/MEN/VIII/2005 concerning the Components and Implementation of the Steps to Achieve 
Decent Living Conditions. It, then, replaced the Ministry of Manpower and Transmigration Regulation No. 13 of 2012 with the same title. After a year, the Ministry of Manpower and Transmigration passed Regulation No. 7 of 2013 concerning the Minimum Wage. Then, the Indonesian government enacted Government Regulation No. 78 of 2015 concerning the Wage. Government regulation No 78 of 2015 was strongly supported by employers because it provided certainty of the amount of minimum wage to be paid. The government used the term "minimum wage" and "wages" for the first time. Even though, in the Ministry of Manpower Regulation No. 21 of 2016 on the Decent Living Conditions a new definition of the minimum wage was included. Differences in perception of the definition of the minimum wage then became a separate debate between the state, workers and employers, which will be discussed in the next section.

\subsubsection{Minimum wage definitions}

The process of influencing the minimum wage policy begins with the definition of the minimum wage. The various opinions on the minimum wage among the state, workers and employers underpin some disputes in Indonesia. The most recent definition of the Indonesian conception of the minimum wage can be found in Ministry of Manpower Regulation No. 21 of 2016 regarding Decent Living Conditions in article 1, clause 2. It defines the minimum wage as "the lowest monthly wage, which consists of a basic wage without wage supplements or a basic wage including a fixed supplement that is approved by the Governor as a safety net". In this definition the term "wage" has a broader meaning than other terms such as remuneration or fee.

Before the regulation was stipulated, there were three regulations that mentioned minimum wage definitions. First, the Ministry of Manpower Regulation No. PER-01/MEN/1999 on the Minimum Wage specifies the minimum wage as the lowest monthly wage including benefits. In the next regulation, Ministry of Manpower and Transmigration No. 7 of 2013 concerning the Minimum Wage, the definition includes elements of social security. The Indonesian government, then, enacted Government Regulation No. 78 of 2015 on Wages. This regulation distinguished the definition of wages and minimum wages. Wages was defined as:

the right of the worker to be paid in the form of money by an employer, which is determined and paid based on a contract of work, agreement, or laws and regulations, including the benefits to the workers and his/her family for the work and/or service incurred or to be incurred. (PP No. 78 of 2015 article $1(1))$ 
In article No. 41(1), it mentioned the minimum wage as the social safety net. Then in article No. 41(2), the minimum wage was defined as the lowest payment that consisted of wages without benefits or basic wages with fixed benefits.

Furthermore, based on Act No. 13/2013 article No. 88 (2), the minimum wage policy aimed to protect citizens to meet their basic needs for living. In other words, the wage policy is one form of social protection for Indonesian citizens. The same objectives were described in the ILO Wage Fixing Recommendation of 1970 No. 135 paragraph 2. The function of the minimum wage as a social safety net is also recognized by employers, workers and government officers who have been involved in the Provincial Wage Council (Sudiono, a member of the Jakarta Wage Council government representative)

The definition of minimum wage could be different among different groups. From the interviews, the government officer adheres to the regulations that the government enacted. For the worker activists the term "wage minimum" should be distinguished from the term "wage". On 12 August 2015, in front of the trial of the judicial review on the Law No. 13 of 2003 on the Manpower to the State Gazette of the Republic of Indonesia of 1945, Tjandraningsih, one of the expert witness, gave her opinion on the term "minimum wage" and "wage". She said that:

the minimum wage is the lowest wage that [can be] legally paid by the employer to their employee or workers for certain work and certain time to fulfil their basic needs. Second, minimum wage is the lowest wage that should [be paid] to the employees or workers that [is] guarantee[d] by Law... Minimum wage is different from wages, in which wages are the domain of workers and employers. It is determined by the agreement that is resulted from negotiations between two parties. (Tjandraningsih as cited in the Court Proceeding of the case No. 72/PUU-XIII/2015, p. 3)

Employers try to interpret the definition of the minimum wage in different way. Sarwana, a member of the Jakarta Wage Council employers' representative, commented that the minimum wage should be differentiated based on educational backgrounds and skills. He is therefore referring to the term "wages" instead of "minimum wage" as mentioned above.

In the debate on minimum wages, the state has consistently referred to the guidance provided by the ILO. This definition is supported by workers. On the other hand, employers do not agree with the application of this definition. That is, the state is more likely to obey international rules than to comply with employers demands. 


\subsubsection{The formulation of minimum wage}

The structuralists believed that the state has a function to maintain the capitalist system by mediating between social classes in times of conflict. But it does not mean the position of the state is neutral. In the wage process how the state performs its function to maintain the capitalist system can be seen in the formulation of the minimum wage as follows.

The Indonesian minimum wage is regulated in Labour Law No. 13 of 2003 articles 88-98 that consist of a wage system and how it can be implemented. Article No. 88 (1) states that "every worker is entitled to get income that meets a decent livelihood for humanity". Other clauses under the same articles note that the government should adopt a wage policy to protect workers, and the minimum wage refers to the basic cost of living by considering economic productivity and economic growth. However, the Labour Law No. 13 of 2003 was one of the three packages of the labour law that was imposed by the IMF. The consideration on economic productivity and economic growth indicated how the Labour law No. 13 of 2003 was intended to maintain the capitalist economic system rather than to protect workers' welfare.

Since the New Order, the Indonesian government has used four different formulas to calculate the minimum wage in each government era. First is Kebutuhan Fisik Minimum (KFM, Minimum Physical Needs) that was used between 1969-1995. This formulation is based on the calculation of the amount of calories required for work within a day. The government determined the basic physical needs was 2,600 calories/capita/day for a single worker. The basic physical needs were broken down into consumer goods, which were considered essential for living, such as food, clothing, and housing. Second, the Kebutuhan Hidup Minimum (KHM, Minimum Subsistence Needs) was applied between 1996-2005. KHM used 3,000 calories/capita/day as the basis for minimum wage calculation. Based on the Ministry of Manpower Decree No. 81/Men/1995, minimum subsistence needs had four groups of consumer goods, food and drink; shelter and supporting facilities; clothing; miscellaneous, and consisted of 43 items. $^{2}$ Both in the minimum physical needs or the minimum subsistence needs, the government also considered the consumption price index, labour productivity levels and the labour market in their determination of minimum wages.

The third, the minimum wage formula was the Kebutuhan Hidup Layak (KHL, Decent Living Needs). The government applied the decent living needs to calculate the minimum wage between 2006-2015. The decent living needs still used 3,000 calories/capita/day to determine the

\footnotetext{
${ }^{2}$ Item is a piece or a unit consumer good, such as clothing, plate, shoes and so on.
} 
basic physical needs of workers to do their work in a day. In the Ministry of Manpower and Transmigration Regulation No. PER-17/MEN/VIII/2005 on Components and Implementation of the Steps to Achieve Decent Living Conditions, the consumer goods were categorized as 7 components and 46 items. The trade union activists believed that the components and the items in Regulation No. PER-17/MEN/VIII/2005 were not adequate for attaining decent living conditions.

In 2009 AKATIGA, Serikat Pekerja Nasional (SPN, National Workers Union), Garteks (Garment dan Textile Union) and Friederich Ebert Stiftung (FES) conducted a Decent Living Conditions survey among garment and textile workers. The survey resulted in 8 components and 122 items being included for decent living conditions (Tjandraningsih, 2009). The survey added miscellaneous components to the list, such as social gatherings, ${ }^{3}$ and taxes. They presented the survey results to the government to revise the number of components and items in the PER17/MEN/VIII/2005. In 2012, the government replaced the Ministry of Regulation with the Ministry of Manpower and Transmigration Regulation No. 13 of 2012 on the Components and Implementation of the Steps to Achieve Decent Living Conditions because of the pressure from workers, NGOs and other stakeholders. This regulation listed 60 items that would be calculated by wage council. The number of goods increased to 14 items with the same basic needs of 3,000 calories/capita/day.

Table 4.1 The comparison of the number of components of the decent living needs between PP No. PER17/MEN/VIII/2005 and PP No. 13/2012

\begin{tabular}{|c|l|c|c|}
\hline No & \multicolumn{1}{|c|}{$\begin{array}{c}\text { Components of } \\
\text { the decent living needs }\end{array}$} & $\begin{array}{c}\text { Ministry Regulation } \\
\text { No. PER-17/MEN/VII/2005 }\end{array}$ & $\begin{array}{c}\text { Ministry Regulation } \\
\text { No. 13 of 2012 }\end{array}$ \\
\hline 1 & Food and drink & 11 & 11 \\
\hline 2 & Clothing & 9 & 13 \\
\hline 3 & Housing and facilities & 19 & 26 \\
\hline 4 & Education & 3 & 5 \\
\hline 5 & Health & 1 & 1 \\
\hline 6 & Transportation & 2 & 2 \\
\hline 7 & Recreation and savings & 46 & 60 \\
\hline & Total of items & & 2 \\
\hline
\end{tabular}

Note: Adapted from regulation No. PER-17/MEN/VIII/2005 and Ministry Regulation No. 13 of 2012.

\footnotetext{
3 Arisan is a regular social gathering where a kind of lottery is conducted and members take turns to win an amount of money previously deposited by all members.
} 
The government did not only increase the number of components and items, they also adjusted the decent living needs on quantity and quality of the goods, and type of needs (e.g., waistbands, and shoe cleaner). There were some improvements in the decent living needs list, determination of quantity, quality and type of goods which later became the source of a heated debate between employers and workers. The debate also occurred in the selection of places to be surveyed, whether in the main traditional market, the medium traditional market or the modern market ${ }^{4}$, because many workers bought in from the nearest modern market.

In this period of the minimum wage system, employers, trade unions and government conducted a survey in some markets, both traditional and modern. This resulted in price differences. The price of goods in the modern market was higher than in traditional markets. More workers preferred to buy their daily needs in the modern market than in the traditional market, because it was usually nearer. Employers tended to use prices from the traditional market, because it lowered the total amount necessary for decent living needs.

Lastly, from 2015 until present, the government has applied a formula to assess the minimum wage based on previous minimum wages, the inflation rate and national economic growth (see chart 4.1). This wage policy was based on the Government Regulation No. 78 of 2015 in Minimum Wages, which was a part of the Fourth Chapter of Indonesian Government Economic Package. The Fourth Chapter was released on 15 October 2015, and aimed to provide minimum wage assurances to the market. The Government Regulation No. 78 of 2015 was indicated as a result of the economic crisis of 2013. The State needed to enact a policy that was aimed at protecting employers interests. As stated by the structuralists, the policy issued by the state is the state's attempt to keep the capitalist economic system running (Barrow, 1993). The government made adjustments to minimum wage policy in line with economic growth and inflation. In this minimum wage formulation, the inflation rate and national economic growth were calculated by National Statistics.

\footnotetext{
$4 \quad$ A traditional market is a place when the seller meets the buyer directly. The price in the traditional market can be
} negotiated between the seller and buyer. A modern market is a supermarket which has fixed prices. 
Chart 4.1. The minimum wage formulations based on Government Regulation No. 78/2015

$\begin{array}{ll}\mathrm{UMn}=\mathrm{UMt}+ & \{\mathrm{UMt} \times(\text { Inflasit }+\% \Delta \mathrm{PDBt})\} \\ \mathrm{UMn} & =\text { New minimum wage } \\ \mathrm{UMt} & =\text { Previous minimum Wage } \\ \text { Inflation } & =\text { Annual inflation rate during a year } \\ \Delta \mathrm{PDBt} & =\text { GDP annual increase during a year }\end{array}$

The new minimum wage formulation, based on the Government Regulation No. 78 of 2015, reduced the opportunities of trade unions to negotiate the amount of decent living needs. The previous calculation of the decent living needs was conducted annually. Based on the Government Regulation No. 78 of 2015, the Wage Council will calculate the decent living needs once every five years.

The last decent living needs calculation was officially performed in 2015 . Some trade unions in the Wage Council still force the government to conduct a survey to determine the decent living needs every year. The trade unions, then, proposed their calculation of the minimum wage to the Wage Council. In the Jakarta Wage Council meeting on 26 October 2016, the trade unions proposed Rp 3,831,690 as the amount of minimum wage for 2017 (Regional office of Manpower presentation slide, 2016). They obtained this amount for the minimum wage based on their survey of the decent living needs, considering economic growth and the national inflation target for 2017. They did not use the annual inflation during 2016. Trade unions calculated the minimum wage following the previous formula, before Government Regulation No. 78 of 2015 was applied by the state.

On the other hand, Indonesian employers were very satisfied with formula in the government Regulation No. 78 of 2015. The Chairman of KADIN, Rosan Roeslani, stated that this minimum wage formula was appropriate and able to increase purchasing power. Employers were also more confident in determining and anticipating wage increases (Andreas, 2017).

The government also felt that the components of the decent living needs were better than in the past. Sudiono from the government office said,

the items in the list had improved in the Wage Council before Government Regulation No. 78/2015. It meant that the Jakarta Wage Council did not use the Ministry of Manpower Regulation No. 13 of 2012 any longer. Then, the list of items included the improved items. For example, drinking water. 
In the Wage Council, the items of decent living needs could change based on negotiation. Sometimes workers could successfully make changes to some items, but only to a certain extent. As explained in an interview, workers could earn $\mathrm{Rp} \mathrm{700,000} \mathrm{per} \mathrm{month} \mathrm{for} \mathrm{room} \mathrm{rent.} \mathrm{In} \mathrm{fact,} \mathrm{Rp}$ 700,000 per month would allow a worker to afford one-room board. However, many workers are married, have children, and receive the minimum wage with no allowances for this.

Responding to workers' demands on a fair minimum wage, the government enacted the Ministry of Manpower and Transmigration Regulations No. 7 of 2013 on Minimum Wage regarding the sectoral Upah Minimum Sektoral (UMS, Sectoral Minimum Wage). At the provincial level, it is called Upah Minimum Sektoral Propinsi (UMSP, Provincial Sectoral Minimum Wage). In the district and city, it is called Upah Minimum Sektoral Kota or Kabupaten (UMSK, District or City Sectoral Minimum Wage). The sectoral minimum wage aims to give a specific wage because of the competitiveness of certain industrial sectors. The sectoral refers to the recent list on the standard classification of Business field of Indonesia that is published by BPS. The amount of the provincial sectoral minimum wage must be higher than the provincial minimum wage that has been approved by the Governor. Employers also have the same concerns with the government, as in the following comment,

Most employers tend to refuse the sectoral minimum wage, because it increases the amount of wages that should be paid by them. They prefer to pay the workers based on their skills and competencies (Sarwana, a member of the Wage Council).

In fact, sectoral minimum wages have made the amount of minimum wage lower than the provincial or district minimum wage. Workers' responses have varied, some have refused, and some have accepted the sectoral minimum wage. The trade unions rejected the sectoral minimum wage because of the wage-cutting in certain sectors. For example, the garment workers in Depok, West Java, who received the sectoral minimum wage were paid at a lower rate than the provincial minimum wage. The Depok city's minimum wage of 2017 was Rp 3,297,489 while the garment sectoral minimum wage of 2017 was Rp 1,4000,000. Minister of Manpower, Hanif Dhakiri, stated that this decision to decrease the sectoral minimum wage was to cope with the impact of the economic crisis. According to the head of the regional office of Manpower of Depok, West Java, this policy was taken to prevent mass lay-offs (Garment workers, 2017, para. 2).

All in all, the state aims to protect the interests of employers when setting the minimum wage. Thus, the state will adjust the minimum wage according to economic conditions and the 
demand from employers and international capital. As mentioned in chapter two, the irregular minimum wage implementation, however, proved Marx's theory of wages. The workers' struggle demanded wage rises and a call for the state to protect the rises; both aspects of the struggle occurred within the constraints of the economic context. When capitalism is in crisis, the companies will press down on the workers wage rather than sacrifice their own profits.

\subsubsection{Decision-making process}

The ILO categorised the minimum wage setting in Indonesia under the "government following the recommendations or consultation of a specialised body" model. The Wage Council recommends the assessment of the decent living needs and the amount of the minimum wage to the government. The structure of the Wage Council can be observed as a strategic-selectivity from changes in form, content and how it operates (Jessop, 2014). The Wage Council is a tripartite body of representatives of workers, employers and the state. As outlined in Chapter 3, tripartite institutional models were introduced during the New Order. At the time, the aim was to control the trade unions and decisions relating to workers. Although this form of organisation does not have much change, its representation and mechanisms are much more democratic than in the New Order. Content can be examined from the recruitment process of trade union representatives. The Wage Council's operating mechanisms can be seen from the wage process that is now not centralised, but more decentralised at the provincial and district levels.

Following local autonomy in the 2000s, the minimum wage is now decided at three levels: national, provincial and cities or districts. At the national level, the government formed the National Wage Council and gave it the responsibility to study the decent living needs once every five years. At the provincial level, the local government established the Provincial Wage Council and the District Wage Council or the City Wage Council.

Based on the Presidential Decree No. 107 of 2004 article 1, the Wage Council is a tripartite non-structural institution. The members of the Wage Council are trade union officials, employers, government officials, and academics or specialists. The ratio of government officials, workers and employers is 2:1:1. Each Wage Council has a different total number of members. In the National Wage Council, the number of members are decided by the Ministry of Manpower and Transmigration No. PER-03/MEN/1/2005. In article 2, the total number of members in the National Wage Council is 23. This total consists of government representatives (10); trade unions officials 
(5); employers organisation members (5); and academics and/or specialists (3). The number of Wage Council members at provincial, district or city levels will be decided by the government institution responsible for manpower, such as regional offices of manpower. For example, the Regional Office of Manpower DKI Jakarta province decided the number of the Wage Council members in 2017 should be 30: 14 from government; 7 from employers organisations; 7 from trade unions; with the additional 2 members being a specialist from university and research institution (Sudiono, a member of the Jakarta Wage Council government's representative).

The number of members who are academics or other specialists on the Wage Council will be determined by the government and will depend on the situation and conditions. This means that the number will increase or decrease as necessary as will the type of expertise required by the Wage Council. The academics and other specialists have a role to provide their perspectives on the minimum wage.

Representatives of the government at the national level come from state institutions such as BPS-Statistics Indonesia, the Ministry of Industry and Commerce, the Ministry of Manpower, and the Ministry of Transportation. Provinces, districts and cities are represented by the relevant regional offices of each ministry, i.e. the Ministry of Manpower has a Regional office of Manpower, the Regional office of Industrial Ministry and the Regional office of Cooperative Small and Medium enterprises Ministry

For employers' representatives, Kamar Dagang Indonesia (KADIN, Indonesian Chamber of Commerce and Industry) officially appoints Asosiasi Pengusaha Indonesia (APINDO, Association of Indonesian Employers) to sit on the Wage Council. This position is legalised by the government through the Ministry of Manpower and Transmigration regulation No. Per-03/MEN/I/2005 concerning the Procedure for nominating membership of the National Wage Council. Although employers' organisations are officially represented by APINDO, there are representatives from KADIN and other employers' organisations within wage council.

Trade unions which represent workers on the Wage Councils generally come from federations or confederations which have bigger memberships than other trade unions. The trade unions should follow a verification process before they can propose to become a member of the Wage Council. The government has some requirements for them. First, they should have registered with the Ministry of Manpower and/or the Regional Office of Manpower. Secondly, they must have at least 10 working units or at least 2,500 members at the district or city level. The trade unions should have 30 working units or at least 5,000 members at the province level. Lastly, they should 
possess 20 per cent of the branches of 34 provinces or have 7 branches in 7 provinces. In the other words, they should have 150 working units or 500,000 members at a national level.

Wage Council is only responsible for calculating the amount of decent living needs. After the calculation process, the Wage Council proposes the amount of decent living needs and the minimum wage to the authorized person according to the level of government. At the national level, the authorised person is the Minister of Manpower. At the provincial level, the authorised person is the governor. At the district or city level, the authorised person is the regent or mayor. Here, the workers' struggle to increase the minimum wage within the Wage Council has dealt with the higher state structure. That is what Jessop (1990) termed "structural constraint".

\subsection{Workers as agents}

In dealing with the higher structure of the Wage Council, workers calculate other spaces, provided by the state, and consider various economic and political conditions. Workers undertake strategiccontext analysis (Jessop, 1990) to develop strategies to influence minimum wage policy outside the Wage Council structure. Before discussing the workers' strategy outside the Wage Councils, this sub-section will explain why the minimum wage is still a major issue for workers. Then, it will discuss, the condition of trade unions in Indonesia. The calculation should consider the strength of workers' organisation.

\subsubsection{Minimum wage as a main issue for trade unions}

Until 2017, the minimum wage was still a major issue for the trade union movement. A number of participants identified some causes, such as the number of violations of the minimum wage, the amount of decent living needs, and the lack of adequate social security for the workers.

Violations of the minimum wage. Referring to statistics from the Data and Information Centre of the Ministry of Manpower (2017), the number of violations of the minimum wage was still higher than other types of violations of workers, such as collective bargaining, overtime payment and Tunjangan Hari Raya (THR). THR is a type of annual allowance that is paid a week before Eid Mubarak (an Islamic celebration after a month fasting). Based on Labour Act No. 13 of 2003, the THR is mandatory. The comparison can be seen in table 4.2. 
Table 4.2 The number of violations of minimum wage, overtime payment, and annual allowances 2011-2017

\begin{tabular}{|r|r|l|l|l|}
\hline Year & $\begin{array}{l}\text { Violations of } \\
\text { minimum wages } \\
\text { (case) }\end{array}$ & $\begin{array}{l}\text { Violations of } \\
\text { overtime pay } \\
\text { (case) }\end{array}$ & $\begin{array}{l}\text { Violations of } \\
\text { THR** } \\
\text { (case) }\end{array}$ & $\begin{array}{l}\text { Violations of collective } \\
\text { bargaining } \\
\text { (case) }\end{array}$ \\
\hline 2011 & 889 & 633 & 218 & 1024 \\
\hline 2012 & 2,165 & 947 & 356 & 2091 \\
\hline 2013 & 3,220 & 1854 & 765 & 2910 \\
\hline 2014 & 3,254 & 1607 & 402 & 2518 \\
\hline 2015 & 2,764 & 2764 & 1279 & 2414 \\
\hline 2016 & 3,873 & 1769 & 375 & 2948 \\
\hline 2017 & $* 3,186$ & 1557 & 310 & $* 2028$ \\
\hline
\end{tabular}

Note: The Data and Information Centre, Ministry of Manpower (2017). Adapted with permission.

*The data was obtained during the second trimester of 2017.

Between 2011-2017, the number of violations of the minimum wage increased. Only in 2015, when the Government Regulation No. 78 of 2015 was enacted did the number of violations of the minimum wage decrease from 3,254 to 2,764 cases. In 2016, when the government had implemented the regulation, the number of violations of the minimum wage climbed from 2,764 to 3,873 cases. In the second trimester of 2017 , the number of violations of the minimum wage were 3,186 cases. For example, in 2016 the number of violations of the minimum wage were 3,873 cases. It was higher than the number of violations of collective bargaining which was 2,948 cases in the same year. As well as other cases that related to wages, the number of violations of collective bargaining was also high in 2015, while the government enacted Government Regulation No. 78 of 2015.

The decent living needs. The minimum wage is still far lower than decent living needs. It can be seen in table 4.3 that illustrates the comparison between the average minimum wage and the average decent living needs between 2010-2017. 
Table 4.3 The comparison of the average minimum wage at national level, minimum wage increase, and average decent living needs 2010-2017

\begin{tabular}{|l|r|r|r|}
\hline Year & $\begin{array}{c}\text { Minimum wage } \\
(\mathrm{Rp})\end{array}$ & $\begin{array}{c}\text { Minimum wage increase } \\
(\%)\end{array}$ & $\begin{array}{c}\text { Decent living needs } \\
\text { (Rp) }\end{array}$ \\
\hline 2010 & 908,824 & 7 & $1,068,399$ \\
\hline 2011 & 988,829 & 8 & $1,123,744$ \\
\hline 2012 & $1,088,903$ & 9 & $1,299,692$ \\
\hline 2013 & $1,355,331$ & 18 & $1,435,015$ \\
\hline 2014 & $1,584,391$ & 14.4 & $1,667,902$ \\
\hline 2015 & $1,790,324$ & 13.5 & $1,813,396$ \\
\hline 2016 & $1,997,819$ & 10 & $1,813,396$ \\
\hline 2017 & $2,073,346$ & 3 & $1,813,396$ \\
\hline
\end{tabular}

Note: Data for the decent living needs were adapted from https://www.bps.go.id/linkTableDinamis/view/id/1212.

Data for minimum rate came from Data and Information Centre Ministry of Manpower (2017).

From 2010 to 2014, the minimum wage tended to increase. After the government stipulated Regulation No. 78 of 2015, the minimum wage increase was inclined to decrease. It only rose about 10\% in 2016 and 3\% in 2017. Talking about this issue, Tri, a researcher from LIPI, said:

I compared the minimum wage before this regulation [No. 78/2015] was enacted. The increase [of the minimum wage] that was about 10 per cent, was a setback... The effect of this decrease for the workers' life was worse, because it meant the level of the real wages was going down.

In fact, decent living needs are still far from the real living cost of the workers. The result of the AKATIGA, FES and trade unions survey showed the workers needed 8 components and 122 items, while the government only listed 7 components and 60 items.

As the basis of the minimum wage, the amount of decent living needs only calculated the needs of a single worker. In fact, the minimum wage needs to cover the living needs of a worker and his/her partner and their children. Thus, the minimum wage will be sufficed to meet the cost of living for a worker and his/her family, if only the minimum wage is much higher than the amount of the decent living needs. Moreover, many enterprises still apply the minimum wage for workers who have worked more than 1 year. It violates the government regulations concerning the minimum wage which states that the minimum wage applies to the workers who work less than 1 year. Although some enterprises provide an allowance to support their family, the amount is very small. This allowance only applies to the male workers who have a family. For female workers who have 
family this type of benefit is often not given. This happens despite the fact that some women workers are the head of their family and finance their children alone. Partogi said that,

a woman worker will be counted as single, although she is married. The allowances are included as a part of her husband's wages. It also applies to women workers who have unemployed husbands or are single parents. However, the amount is not very much. In a factory at Bekasi District the allowance is about $\operatorname{Rp} 10,000$ a day. ${ }^{5}$

The social insurance system. The social insurance system in Indonesia is insufficient to support workers' welfare. In Indonesia, there are two institutions which manage the national insurance system: Badan Perlindungan Jaminan Sosial Kesehatan (BPJS Kesehatan, Social Insurance Administrative Body Healthcare Security) and Badan Perlindungan Jaminan Sosial Ketenagakerjaan (BPJS Ketenagakerjaan, Social Insurance Administrative Bodies for Manpower Security). BPJS Ketenagakerjaan consists of: Jaminan Keselamatan Kerja (JKK, Work Accident Insurance); Jaminan Hari Tua (JHT, Old Age Insurance); Jaminan Pensiun (JP, Pension Insurance); and Jaminan Kematian (JK, Death Insurance). The JK provides cash benefits to the heir of a worker who dies because of an accident outside the workplace or not on duty. JHT provides a cash benefit to the workers if they have reached 56 years old, dies and/or have a permanent disability. JP provides cash benefits if the insured workers reaches pension age, dies or has a permanent disability. The difference with JHT is if the insured is still alive, the benefits will be gradually given until the insured person's death. The JP only applies for the wage earners

Both BPJS Kesehatan and BPJS Ketenagakerjaan are paid into by the workers and employers. The enterprises cut their monthly wages to pay social security charges. The ratios of contribution that should be paid by the workers and the employers are $4: 15.68$. In the other words, the workers have contribution about one-fourth the amount of an employer. However, most workers still get payment at the minimum wage level, that aims to cover the living costs of a single worker. The four per cent deduction of minimum wage to cover social insurance costs will have a significant impact on a worker who has a family. There will be some components of the living costs that should be reduced.

Allowance only paid for the working days. If there is any holiday or day off, the labour cannot get the allowance. 


\subsubsection{Workers' struggle for minimum wage}

\subsubsection{Trade Unions}

Trade unions are an important component of the workers' struggle. The number of the trade unions will affect the size of the workers struggle. As described in chapter 3, the number of trade unions was strongly influenced by the economic and political situation in Indonesia. After the workers' movement weakened during the New Order, the trade unions grew in the reform era.

In Indonesia, the reformation brought freedom of speech and freedom of association and it influenced the number of trade unions. On 5 June 1998, two weeks after the fall of the Suharto regime, the President of Indonesia B.J. Habibie, enacted Presidential Decree No. 83 of June 1998. It ratified the ILO Convention No. 87 concerning the Freedom of Association and Protection of the Right to Organise. Then, on 22 July 1998, the Transition Minister of Manpower, Fahmi Idris, enacted Regulation No. Per-05/MEN/1998 concerning the Trade Unions Registration. This regulation required all trade unions to register with the Ministry of Manpower and its regional offices. It needed to be done no later than 90 days following the enactment of the rule. After the Indonesia government enacted Law No. 21 of 2000, the Minister of Manpower legalized Decree No. Kep.16/MEN/2001 concerning the procedure to register trade unions. This decree also obligates the existing trade unions to register and receive a record number from the Ministry of Manpower. The registration needed to be within one year following the enactment of the decree.

Five years after ratification of the ILO convention, the trade unions in Indonesia were increased from 1 trade union to 74 trade unions (Mizuno, 2005). Referring to their history, the trade unions in Indonesia can be categorized into three groups. First was the Serikat Pekerja Seluruh Indonesia group (SPSI, All Indonesian Workers' Unions). Second was the ex-SPSI, which formed after a split from the SPSI. Third were trade unions that were not previously affiliated with SPSI (Tjandraningsih, 2010). During the 2000s, the Konfederasi Serikat Pekerja Seluruh Indonesia (KSPSI, Confederation of All Indonesian Workers' Unions) split into three organisations: the KSPSI (KSPSI, Confederation of All Indonesian Trade Unions) led by Andi Gani; KSPSI led by Yoris Raweyai; and the KSPSI led by Syukur Sarto. Andi Nuwa Wea has been elected President of the KSPSI since 2011. He is a politician from the Partai Demokrasi Indonesia-Perjuangan (PDI-P, the Indonesian Democratic Party of Struggle). His father, Jacob Nuwa Wea, was the Minister of Manpower and Transmigration between 2001-2004, and also the former chairman of K-SPSI. 
Similarly, the President of K-SPSI Yoris Raweyai, is a politician from Golongan Karya (GOLKAR, the Party of the Functional Group), and also a member of Pemuda Pancasila (PP, Pancasila Youth Group).

Some non-SPSI affiliated organisations were independent trade unions, that can be categorized into two groups (Tjandraningsih, 2010). First, the trade unions that were established following the New Order, such as Gabungan Serikat Pekerja Merdeka Indonesia (Gaspermindo, Federation of Free Trade Unions) and Gabungan Serikat Buruh Indonesia (GSBI, Federation of Indonesian Trade Unions). Second, the trade unions that were totally new and did not have any relationship with trade unions under the Suharto regime, such as Konfederasi Kongres Aliansi Serikat Buruh Indonesia (Konfederasi KASBI, Confederation of Congress of Indonesian Unions Alliance); Front National Buruh Indonesia (FNPBI, National Front of Indonesian Workers Struggle); and Konfederasi Serikat Nasional (KSN, National Alliances Confederation).

Table 4.4 The number of confederations, federations, and trade unions in the factories in Indonesia 20102017

\begin{tabular}{|c|c|c|c|}
\hline Year & Confederations & Federations & $\begin{array}{c}\text { Trade Unions in } \\
\text { factories }\end{array}$ \\
\hline 2010 & 4 & 90 & n/a \\
\hline 2011 & 6 & 91 & 11,852 \\
\hline 2012 & 6 & 92 & 11,852 \\
\hline 2013 & 6 & 92 & 11,852 \\
\hline 2014 & 6 & 92 & 11,852 \\
\hline 2015 & 8 & 101 & 6,808 \\
\hline 2016 & 14 & 112 & 7,294 \\
\hline 2017 & 14 & 115 & 7,294 \\
\hline
\end{tabular}

Note: Adapted from the Data and Information Centre, Ministry of Manpower of the Republic of Indonesia, 2017.

After the Indonesian reform era, the growth and the decline in the number of trade unions, federation and confederation can be seen on table 4.4. From 2010 to 2017, the trade unions' confederation increased 71 per cent and the federation rose approximately 25 per cent. On the other hand, the number of trade unions in the factory level declined from 11,852 in 2011 to 7,294 in 2017. While the number of trade unions' membership declined from 3,414, 455 people (in 20102014) to $2,717,961$ people (in 2015-2017). However, the growth in the number of confederations and federations which were not followed by the increase in the number of trade unions indicated some factors that affected the workers to join trade unions.

A few participants reported there were some factors that influenced the decrease in trade union members. Firstly, the massive relocation of some industries to other areas, in which there 
were no trade unions. In the last few years the government has opened several new industrial areas in Central Java, West Java and East Java. The trade unions, mostly the small organisations, cannot reach those areas due to a lack of funds. For this case, Partogi, a trade union activist from KASBI, commented that

the trade unions cannot directly draw membership contributions from their members through wage payments that were made by the factories to the workers. Only the big trade unions can do this, such as SPSI. The membership contributions can only be done manually person to person.

To deal with this situation, some independent organisations have tried to fund themselves to cover the operational costs of trade unions. They created some activities to generate income such as: collaborating with national and international NGOs to develop a project i.e. campaign, advocacy, worker education or research; selling organisational newsletters; and establishing an organisational business unit. Despite this, some organisations prefer not to form partnerships with NGOs except for advocacy activities, as Partogi added:

Our trade union choose to fund itself, to retain independence. Even though, it is very hard. We try to collect the fee from our members between 0.5 per cent- 1 per cent of their wages. It is now going quite well.

In comparison, big trade unions, such as Konfederasi Serikat Pekerja Indonesia (KSPSI, Confederation of Indonesia Trade Unions) collected contributions from approximately one per cent of their members. One member of KSPSI, Federasi Serikat Pekerja Metal Indonesia (FSPMI, Federation of Indonesian Metal Workers Union), contributed between 1.4-1.7 Billion Rupiah per month. From the total amount of contribution, the members used 60 per cent of the contribution in their factory and 40 per cent of the contribution for KSPSI (Metrotvnews, 2016).

The number of confederations increased by over 50 per cent from 4 confederations in 2010 to 14 confederations in 2017. Similarly, the number of federations increased from 90 federations in 2010 to 115 federations in 2017. Partogi, a trade unions activist, stated that "the rise of confederation and federation was indicated as the result of the way of trade unions anticipating the lack of fund".

The increase in the minimum wage also affected the interest of the workers to join in a trade union. Yanti, a trade union activist from GSBI, said that "the workers do not want to join a trade 
union because they feel satisfied with the minimum wage that they have received". Answering the same question, Anwar, a trade union activist from KPRI added information that, "the reluctance of worker to join trade unions mainly occurs in areas where the amount of minimum wage is higher than other regions such as South Tangerang and Bekasi”.

The political situation in Indonesia also impacted on the number of trade union members. Many trade union members left their organisation because there was a conflict in the internal organisation that related to pressure from the fundamentalist Islamic group. The fundamentalist Islamic group wanted to build a state based on Islamic law in Indonesia. They used some issues, such as communism versus Islam and Chinese descendants versus the indigenous population. The communism issue was the legacy of the New Order to get rid of political opponents. The existence of a Chinese population was developing due to some Chinese employers' wealth and investment in Indonesia. Chinese-owned businesses had been benefitting from the politico-bureaucrat environment since the New Order.

Talking about these issues, three participants (Hendra, Partogi, \& Yanti), who were interviewed at different times and locations, provided the same example of a situation before the DKI Jakarta Governor election in 2016 that became heated due to the pressure from Fundamentalist Islam group. The participants said some trade unions, such as KSPSI also tended to use this issue at the grass-roots level to gain voters for a candidate of the DKI Jakarta governor election. In the DKI Jakarta governor election, Anies Baswedan and Sandiaga Uno were identified as the muslim candidates who willing to increase the well-being of local citizens of Jakarta. The local Jakarta citizens are ethnically Batavian and mostly Muslim. The other candidates of the DKI Jakarta governor were Basuki Tjahaya (Ahok) and Djarot. Some supporters of Anies Baswedan and Sandiaga made accusations against Ahok. The supporters believed that if Ahok was elected as governor, he would ensure greater benefits to Chinese descendants who were Christian than to the indigenous-Muslim population in Jakarta (Cochrane, 2017). Related to this issue, Partogi, a trade union activist, felt that,

This issue was influential for us. It forced the members to leave our trade union. The members felt the organisation did not support their religion. They considered the aims of the organisation were different with the aims of their religion. But, then, they come out by themselves. Unfortunately, at the grass root level, the issue turned to anti-communism, that our union was red [leftist or communist]. They insisted that stars [their logo] meant it was communist or socialist, and we were anti-God [atheist], etc. 
The trade unions, particularly some independent trade unions, also used a persuasive strategy rather than confronting the issue. Hendra, a trade unions activist from Konfederasi Serikat Nasional (KSN, Confederation of National Unions), when asked about their strategy, said,

Not all our union members have the same mindset and background. They came from different environments. Some members had a religious family. Thus, we should discuss patiently with them about the aim of organisations, and persuade them to think again about the concrete goal of unions, such as wages and their rights as workers. Also, we persuaded the members to talk about pluralism in our discussion. To think, that we are all different. But, obviously, that was hard for us. we were struggling to make them stay in the trade unions, because, you know, they [Islamic conservatism group] always consolidated themselves after the Friday prayer in the mosques. And, we, the trade unions, found it quite difficult to gather the members. Even just once a month.

Further, the enterprises continued to intimidate workers and trade unions. Partogi said that the forms of intimidation to pressure trade unions and its members was the same as it had been in the past. He identified that there was intimidation coming from military personnel and preman, ${ }^{6}$ which paid enterprises to protect their production processes in factories. Sometime the trade union organisers were followed or threatened by the military after a discussion or meeting with members of the factory. In another case, the members, who were still working in a factory, got a verbal threat from their supervisor because they attended a meeting or discussion organised by the trade union. In other cases, workers were moved to another unit, downgraded to a lower position, suspended or dismissed.

Similarly, Lembaga Bantuan Hukum Jakarta (LBH Jakarta, the Jakarta Legal Aid Institute) recorded complaints on labour relations and criminalization of trade union activists, which related to the freedom of association, as can be seen in the table 4.5

\footnotetext{
6 Preman is an Indonesian term for gangster.
} 
Table 4.5 The number of complaints on labour relation, freedom of association and criminalisation of trade union activists 2011-2017

\begin{tabular}{|c|c|c|c|c|}
\hline \multirow{2}{*}{ Year } & \multicolumn{2}{|c|}{ Labour relation } & $\begin{array}{l}\text { Freedom of } \\
\text { associations }\end{array}$ & $\begin{array}{l}\text { Criminalisation of } \\
\text { trade union activists } \\
\text { (case) }\end{array}$ \\
\cline { 2 - 5 } Complaints & $\begin{array}{l}\text { Number of Justice } \\
\text { seekers }\end{array}$ & & 1 \\
\hline 2011 & 30 & 751 & 11 & 4 \\
\hline 2012 & 74 & 4,680 & 3 & 5 \\
\hline 2013 & 99 & NA & 6 & N/A \\
\hline 2014 & 115 & 24,253 & 7 & N/A \\
\hline 2015 & N/A & N/A & 7 & 1 \\
\hline 2016 & 122 & 9,969 & 4 & NA \\
\hline 2017 & 99 & 2,932 & 1 & 1 \\
\hline
\end{tabular}

Note: Adapted from The Year-end Notes of LBH Jakarta, from 2011-2017.

Before and after 2015, the number of complaints regarding labour relations was significantly higher than other years. In 2014, there were 115 cases, which involved 24,253 workers. In 2016, the number of labour relation cases increased to 122 cases, but the number of justice seekers decreased to 9,969 workers. On the contrary, the number of direct violations of the freedom of association and the criminalization of trade unions activists tended to decrease. In comparison, the Asia Monitoring Resource Centre (AMRC) recorded at least 6 cases that related to labour relations, freedom of association and criminalization of trade union activists between 2015-2016 (Mufakhir, 2016). The high number of cases, which placed pressure on trade unions and their members between 20152016, appears connected to the enforcement of Government Regulation No. 78 of 2015 concerning wages, that changed the formulation of minimum wages.

Moreover, a number of participants believed that the apprenticeship programme, fixed-term contracts and outsourcing of work had affected the number of workers joining a trade union. These work systems, obviously, are part of the flexible labour market programme that was mentioned in the LoI between Indonesia and the IMF in 2003. These work systems benefit employers because they can easily adjust the number of workers according to production targets; the employers have been able to decrease the costs of production by approximately 20 per cent (Tjandraningsih et.al, 2010).

However, these work systems do not benefit the workers. First, the workers deal with the uncertainty of income and job sustainability. The government regulations allow for a fixed-term contract for 2 years. Then, the contract can be extended once, but it cannot exceed more than 3 
years. The worker status should be changed to permanent worker if they have worked more than 3 years in the same enterprise. In practice, most enterprises dismiss the workers every year, and then recruit them again the next year (interview with Abidin \& Yanti). A study in 2010 found that there was approximately 40 per cent outsourcing of worker in the metal industry (Tjandraningsih, 2010). This number could be higher in massive industrial concerns, such as garment and textile manufacturing. Second, such workers will receive lower payments than permanent workers. The total wages of the fixed-term contract workers is 17 per cent lower than the permanent workers. The total wages of the outsourcing workers is 26 per cent lower than permanent workers (Tjandraningsih et.al., 2010). The apprenticeship workers receive wages that are 30 per cent lower than permanent workers (interview with Yanti). Third, the apprenticeship, outsourcing and fixedterm contract workers, both direct and indirectly, cannot join the trade unions. Thus, the workers cannot fight for their rights. At the same time trade unions find it difficult to sign up new members.

\subsubsection{Trade unions' strategies}

A number of participants identified three strategies that were conducted by the workers to influence the amount of minimum wages. First the workers attempted to involve the Wage Council. Second, the trade unions proposed a judicial review of the Laws and the Regulations which are presumed not to favour the interests of the workers. Third, the trade unions used demonstrations and strikes to force the employers and the government to increase the minimum wage. This section, however, will only highlight two of the strategies because the role of trade unions in the Wage Council has been clearly described in previous section.

Judicial Review. The mechanism of judicial review in Indonesia is divided into two processes. First, the judicial review of the laws against the Indonesian Constitution is proposed to the Constitutional Court. Second, the judicial review of government regulations against the law or the higher regulations is proposed to the Supreme Court. However, the judiciary, both the Constitutional Court and the Supreme Court, that conduct judicial review only act as a negative legislator, which means, the judiciary can only declare the content of the norms or the whole norms in the legislation and does not have a binding legal force.

For the trade unions, the judicial review can be a legitimated bargaining process to force the government to change the laws or the regulations. Since 2001, the workers and the NGOs proposed a judicial review on some laws and regulations related to: Act No. 13 of 2003 on Employment; Act No. 21 of 2000 on Trade Unions; Act No. 2 of 2004 on Industrial Relation Dispute Settlements; and 
the decision on the amount of minimum wages at provincial, district and city levels. Until 2016, the Constititutional Court had trialled the laws and regulations related to Act No. 13 of 2003 more than 17 times. From those numbers, nine were granted, two were still in process, and the rest were withdrawn or were rejected (Hukumonline, 2016). In the update on 2017, Hukum online (2016) reported that the Constitutional Court had granted 11 judicial reviews of Act No. 13 of 2003 on manpower. There were four judicial reviews that directly related to wages.

The judicial review is usually proposed by a trade union, alliance of some trade unions, an individual, or the mixed alliance between some trade unions and some NGOs. Before 2015, they, mostly, proposed the article in the Laws or regulations that related to violations of the minimum wage. Because in Act No. 13/2003, the rule of the payment of the wages was not clearly explained. Thus, the employers can easily not pay the workers' wages if they are granted a suspension of the minimum wage by the government.

After the government enacted Regulation No. 78 of 2015 concerning the Wages, the trade unions also set up an alliance to propose the judicial review on this regulation. A trade union alliance, which proposed a judicial review on Regulation No. 78/2015, was Gabungan Buruh Indonesia (GBI, Indonesian Labour Alliance) consisted of: Konfederasi Serikat Pekerja Seluruh Indonesia (KSPSI, Confederation of All Indonesian Unions Workers); Konfederasi Serikat Buruh Sejahtera Indonesia (KSBSI, The Confederation of Indonesia Prosperity Trade Union); KSPSI led by Andi Gani; Konfederasi Perjuangan Buruh Indonesia (KPBI, Confederation of Indonesia Labour Struggle); Konfederasi Kongres Aliansi Buruh Indonesia (Confederation of Congress of Indonesian Unions Alliance); Federasi Serikat Pekerja Aneka Sektor Indonesia (FSPASI, Federation of Workers Unions of Various Sectors of Indonesia); Serikat Buruh Sejahtera Indonesia 1992 (SBSI 1992, The Confederation of Indonesia Prosperity Trade Union of 1992); Gabungan Serikat Pekerja Merdeka Indonesia (Gaspermindo, Federation of Free Trade Unions); Gabungan Serikat Buruh Indonesia (GSBI, Federation of Indonesian Trade Union); and Gabungan Organisasi Buruh Seluruh Indonesia (GOBSI, Federation of All Indonesian Labour Organisations). All the trade unions in GBI had different political affiliations and interests, but they tried to marginalize political differences to have more power to force the government to revoke Regulation No. 78 of 2015.

Since 2015, Government Regulation No. 78 of 2015 has been submitted four times for judicial review in the Supreme Court; three times filed by the unions and once by the employers. These four lawsuits were unacceptable because, in the same time, the Manpower Law No. 13 of 2003 was also being processed in the Constitutional Court. Following, the rejection of the legal 
action against the Government Regulation No. 78 of 2015 concerning the Wages, the trade unions did not give up. In March 2017, KSPI submitted the judicial review on this same government regulation and article. They submitted the same articles to be reviewed by the Court. Said Iqbal, the President of KSPI, explained "article 44, clause 2 of the Government Regulation on the Wages caused the cheap wages, has eliminated the workers' rights for bargaining and the value of the increase of the minimum wage in the dense industrial areas has been decreased" (Kabarburuh, 2015).

Workers' strikes. A number of interviewees believed that a judicial review is not the only strategy to force the government to change their regulations. The workers should continue to enforce the result of Judicial Review to the government through any other available forms of struggle, such as striking. Some trade unions are convinced that striking is the last option if negotiations or legal action have failed. Similarly, Reta Hutabarat, a member of Coalition of Civil Society, commented that "The national strike being taken out by Indonesian workers is the last resort. Previously, workers have done various persuasive ways either to the government, or to the company to demand welfare improvements. However, their efforts are deadlocked" (as cited in Ihsanuddin, 2013). The costs are incurred by the workers when a strike is not small scale. However, that is not just a matter of funds spent to rent a bus, make leaflets, socialize among the workers and build an alliance among the trade unions. The workers may also experience worse effects such as losing their job, criminalisation or being sent to jail for several months. While, other interviewees argued that the demonstration or strike should be combined with legal action or negotiation. Because for the workers, the strikes will strengthen the negotiation or legal action process.

In the post-reform era, the period 2010 to 2017 was the important time for the trade union movement in Indonesia. Strikes on minimum wages took a place in industrial areas in Jakarta, Tangerang and Bekasi. These strikes occurred after trade unions took various negotiations with the government and companies to raise the minimum wage. The Data and Information Centre of the Ministry of Manpower (2017) showed that the number of workers' strikes were always more than 100 times in each year, except on 2012, as seen on table 4.6. Even though, some interviewees believed that the number of strikes on 2012 were high and it was not recorded by the government. 
Table 4.6 The number of strikes, workers involved and hours lost 2010-2017

\begin{tabular}{|r|r|r|r|}
\hline Year & Number & Workers involved & Hours lost \\
\hline 2010 & 192 & 125,784 & 812,131 \\
\hline 2011 & 127 & 46,198 & 327,355 \\
\hline 2012 & 51 & 13,753 & 28,873 \\
\hline 2013 & 239 & 32,209 & 130,999 \\
\hline 2014 & 193 & 48,212 & 265,166 \\
\hline 2015 & 124 & 85,406 & 571,640 \\
\hline 2016 & 122 & 51,626 & 702,901 \\
\hline $2017 *$ & 25 & 8,398 & 102,304 \\
\hline
\end{tabular}

Note: Adapted from The Data and Information Centre of Ministry of Manpower of Republic of Indonesia. * until March 2017.

The high number of workers' strikes was started in 2010. Forum Buruh DKI Jakarta (Trade Unions Forum DKI Jakarta), that consisted of: Asosiasi Pekerja Indonesia (ASPEK Indonesia, Indonesian Workers Association); Federasi Serikat Pekerja Metal Indonesia (FSPMI, Federation of Indonesian Metal Workers' Union); Federasi Serikat Buruh Indonesia (FSBI, Federation of Indonesian Trade Unions); Serikat Pekerja Nasional (SPN, National Workers Unions), and other trade unions, held the mass strikes in Kawasan Berikat Nusantara, which is a large industrial area in Cakung, Cilincing, North Jakarta. They demanded the increase of the Jakarta minimum wage. Until 2017, Forum Buruh DKI Jakarta was a trade union alliance that consistently fought for a fair minimum wage for the workers in DKI Jakarta.

Then, in 2011, several trade unions went on strike. One of the actions, which was claimed to inspire the national strike in 2012, was the strike undertaken by KASBI in Tangerang, in December 2012. Sultoni, a KASBI activist, said that "their strike was to stop the cheap wages and the politics of flexibility [of the labour market]" (as cited in Felisiani, 2011, para. 1). Previously, the alliance of the trade unions went on strikes in Batam for 2 days. They appealed for an increase in minimum wages according to their decent living needs survey. The result of the government survey was $\mathrm{Rp}$ $1,302,992$ while their survey was a wage of $\mathrm{Rp} 1,956,000$. The survey result was then reduced by approximately 10 per cent. Therefore, the workers demanded the minimum wage suggested Rp $1,760,400$. The first day of the strike ended with shootings by the police. The second day ended with riots (Hidayat, 2011). The escalation of workers' strikes increased in 2012. Table 4.7 is a summary of the workers strikes during that year. 
Table 4.7 A summary of the 2012 workers' strikes

\begin{tabular}{|c|c|}
\hline Month & Actions \\
\hline January to February & $\begin{array}{l}\text { The Tol of the Cikampek Road and } 7 \text { industrial regions in } \\
\text { Bekasi were blocked by } 1,000 \text { workers. As a protest against } \\
\text { the denial of the employer, who cancelled the revocation of } \\
\text { the District Minimum Wage (UMK). }\end{array}$ \\
\hline March-April & $\begin{array}{l}\text { The trade unions leading the movement against the } \\
\text { government planned to increase the fuel price. The trade } \\
\text { unions demanded a wage adjustment to the fuel price if the } \\
\text { fuel price should rise. }\end{array}$ \\
\hline May & $\begin{array}{l}\text { May day } 2012 \text { was claimed as the biggest May day in Asia. } \\
\text { There was a huge vergadering that was attended by } 3 \\
\text { confederation and } 6 \text { federations with approximately } 160,000 \\
\text { workers. } \\
\text { On the other hand, the leftist trade unions, that rejected to } \\
\text { join in MPBI, incorporated in Sekretariat Gabungan (The } \\
\text { Joint Secretariat) were FPBI, GSPB, Federasi Progressif, } \\
\text { FSPOI, ISBI, KPO- PRP, and PPR. They marched to Istana } \\
\text { Merdeka, the office of the President of Republic of } \\
\text { Indonesia. }\end{array}$ \\
\hline May to August & Geruduk Pabrik in Bekasi District. \\
\hline October & GETOK MONAS. \\
\hline November to December & $\begin{array}{l}\text { The strike expanded to other areas. Employers paid preman } \\
\text { to fight the workers' strike. }\end{array}$ \\
\hline
\end{tabular}

The triggers of the magnitude of the workers' strike on 2012 was Geruduk Pabrik in Bekasi. As cited from Koran Pembebasan (the Liberation Newspaper),

one of important strikes during this year was Geruduk Pabrik ${ }^{8}$. That was started with eliminating the outsourcing of work in PT. Hero Spk at the end of May. It officially ended with the Bekasi Harmony Declaration on November 8, 2012. The peak mobilization of solidarity action occurred on September 29, 2012 in PT. Patria. There were approximately 10,000 workers gathering solidarity for the outsourced workers in PT. Patria. (Sherr rinn, 2012, para. 3).

Bekasi District is the biggest workers' enclave, in which the actions held in this area affect other areas. This district has some industrial regions, such as Jababeka I, Jababeka II, East Jakarta Industrial Park (EJIP), Delta Silicon I, Delta Silicon II, and MM2100. One of the largest industrial

\footnotetext{
Vergadering is a public meeting.

8 Geruduk is a term from Javanese that could be interpreted as "attack en masse". While, pabrik is manufacturers or factories.
} 
regions named Jababeka, in Cikarang. The Jababeka industrial region has 1,650 companies from 35 countries that settled in the 5,650 ha area (Jababeka, n.d). In 2012, the population in Bekasi District was approximately $2,786,638$ people, with the workforce approximately $1,301,175$ people and approximately 852,269 people working as workers in the processing and services industries (Biro Pusat Statistik (BPS), 2017). Indeed, the number of factories and the density of the workers also supported the workers' consolidation of power in this area.

The Geruduk Pabrik was a solidarity action among the factories, cross-industry, and crossregion that was initiated by Serikat Pekerja Aneka Industri-Federasi Serikat Pekerja Metal Indonesia (SPAI-FSPMI, Various Industry Trade Union-Federation of Indonesian Metal Workers' Union). The goal of the workers was to eliminate the outsourcing of work, reject cheap wages and guarantee national health security. The strike was then followed by Forum Komunikasi dan Informasi KSPSI Bekasi (FKI FSPSI Bekasi, Communication and Information Forum of KSPSI Bekasi). The workers developed a short message centre (SMS centre) to consolidate their actions. In addition to Gerebek Pabrik, the workers also set up Rumah Buruh (the workers house), in which the workers could meet with other workers, discuss the recent situation, and learn about some theories related to their situations, such as the economy and politics (Sherr rinn, 2012).

During the year, there were some important results as KOMAF FISIPOL UGM reported oin their website,

First, there were approximately 50 factories that changed the status of approximately 40,000 outsourced workers to permanent workers. Second, until November 2012, Forum Komunikasi dan Informasi KSPSI Bekasi (FKI KSPSI Bekasi, Communication and Information Forum of FSPSI Bekasi) had been successful in releasing 12,000 outsourced workers to become permanent workers. Third, PT. HI Bekasi had changed the status of approximately 200,000 workers to become permanent workers. The rest, approximately 500,000 outsourced workers received direct contracts (Azizi, et al. 2017, KOMAF FISIPOL UGM, para. 4).

FSPMI and KSPSI had the role of main leadership in these actions; they obtained many additional members, approximately 100,000 workers at the factory level. Sherr rinn, SPAI-FSPMI activist in Koran Pembebasan (2012), noted that they could organize over 1,000 workers per day. This was based on the number of the workers who visited their Workers Houses during the period of strikes. Another trade union, Federasi Perjuangan Buruh Indonesia (FPBI, Federation of Indonesian workers Struggle), said that their members increased from 2,000 to 12,000 (Silaban, as 
cited from an article from Prakarsa Rakyat, 2013).

For the workers, Bekasi district became one of the districts with the highest minimum wage in Indonesia. The Bekasi district minimum wage was Rp 1,168,974 in 2010, Rp 3,601,650 in 2017 and $\mathrm{Rp} 3,915,353$ in 2018. In comparison, the Jakarta minimum wage was $\mathrm{Rp} 1,188,010$ in 2010, $\mathrm{Rp}$ 3,300,000 in 2017, and Rp 3,600,000 in 2018.

When the workers were striking, the local communities joined some organisations such as Masyarakat Bekasi Bersatu (MBB, the United of Bekasi Society), Gerakan Masyarakat Bawah Indonesia (GMBI, Movement of the Lower Society of Indonesia), and Permuda Pancasila (PP, Pancasila Youth), for the purpose of attacking members of trade unions. One by one the workers stepped down from the strike. This massive strike ended with the signing of "A Harmonisation Agreement" in 2012. Among signatories was the chief of FSPMI Bekasi, Obon Tabroni; the chief of SPSI, Abdullah; APINDO; the Local government of Bekasi and some mass organisations in Bekasi. The word of "harmonisation" referred to the Pancasila Industrial Relation that formed in the New Order. It was still used by the employers and the state to delay trade unions strikes.

In the same year, the trade unions undertook the biggest strike in the history of Indonesia that was called GETOK MONAS or Gerakan Tiga Oktober-Mogok Umum Nasional (the third of October Movement-the National General Strike). Some newspapers and trade unions claimed that the strike was the first general strike of Indonesian workers since 1965. An interviewee highlighted that this was the biggest general strike in the Asia Pacific, involving approximately 2,000,000 workers. For example, KASBI, one of the trade unions that was involved in the strike, took their strike to the Pulogadung and Cakung Industrial regions of East Jakarta; Marunda, Tanjung Priok Penjaringan, North Jakarta; International Airport Sukarno-Hatta, Tangerang, Banten and Bekasi, West Java (Kuwado, 2012). The trade unions under MPBI took the strike to approximately 80 industrial areas throughout Indonesia.

Simultaneously, national strikes occurred between 28 October and 1 November 2013. The trade unions joined the Komite Nasional Gerakan Buruh (KNGB, National Committee of Trade Unions Movement). The strike took place in 20 provinces, 150 districts/cities, and 40 industrial regions and involved approximately 2,000,000 workers (Mogok nasional, 2014, para. 2).

Some strikes continued in Indonesia until 2017 in response to the low minimum wage and the outsourcing of work issues. This political situation, then, divided the trade union movement, which had been quite solid in previous years, into two parts: the supporters of Joko Widodo 
(Jokowi) and Jusuf Kalla (JK); and the supporters of Prabowo Subianto and Hatta Radjasa. Said Iqbal, a chief of KSPSI, set up a political contract with the Prabowo-Hatta. The other trade unions that supported Prabowo-Hatta were KSPSI led by Yoris Raweyai and KSPSI led by Sjukur Sarto. Even by the end of election time, KSPSI-Sjukur Sarto changed their support to Jokowi-JK. On the other hand, KSPSI led by Andi Gani and KSBSI supported Jokowi-Jusuf Kalla. To respond this situation, some trade unions activist, and trade unions also declared the Komite Politik Buruh Indonesia (KPBI, the Political Committee of Indonesian Labours) to support Jokowi-JK. The issues of Islamic conservatism, communism and anti-China were also begun to spread among the workers, and it contributed to the degradation of trade unions, as explained in the previous section.

Overall, Jessop (1990) argued the structure when performed strategic-selectivity tended to provide privileges for certain agents or strategies. Another agent who did not benefit from the structure will build a new strategy. Similar to the Jessop's argument, wage councils, as a stateformed structure to recommend minimum wages, also performed strategic-selectivity that seems intended to accommodate the interests of employers. As a result, workers developed strategies to influence minimum wages beyond the Wage Council, through judicial review and strikes.

After the New Order, Judicial Review and workers strike were possible because the state provides space to do both strategies. The State protects the right of workers to organize and freedom to express in the public sphere. The state also established mechanisms to propose the judicial review, through the Supreme Court and the Constitutional Court. Although when using the democratic space provided by the state, trade unions must face other challenges from the fundamentalist Islamic group, that hamper trade union's consolidation.

\subsection{The role of employers' organisations and politician with the employers background.}

Another major agent in this process are employers. According to Miliband's Instrumentalist approach, employers seek to influence state policy by engaging directly in institutions that hold state power (executive and parliaments). They also try to exert influence through employers' organisations, which act as lobbying and suppressing agents, or through organisations within government institutions, such as the Wage Council and the Tripartite Cooperation Institution. 


\subsubsection{Employers' organisations}

The two organisations which have significant political role related to minimum wage are Kamar Dagang dan Industri Indonesia (KADIN, Indonesian Chamber of Commerce and Industry) and Asosiasi pengusaha Indonesia (APINDO, Indonesian Employers' Association). KADIN is an umbrella organisation for all employers in Indonesia, while APINDO is a cross-sectoral corporate organisation.

\subsubsection{Kamar Dagang dan Industri Indonesia (KADIN, Indonesian Chamber of Trade and Industry)}

KADIN was established at the provincial level which was called Kadin Daerah tingkat I (Kadinda tingkat I, Indonesian Chamber of Trade and Industry first level region). On 24 September 1968, Kadinda DKI Jakarta initiated a national conference that formed KADIN. The government recognised the conference agreement and stipulated Presidential Decree No. 49 of 1973 on the Indonesian Chamber of Trade and Industry.

On 1987, Indonesia government enacted Law No. 1 of 1987 on the Indonesian Chamber of Commerce and Industry. Based on the Law, KADIN's members, Dewan Koperasi Indonesia (Dekopin, Indonesian Cooperative Council) and representatives of the state-owned enterprises reformed the Indonesian Chamber of Commerce and Industry. Thenceforth, Indonesian business people, whether they join or do not join an employers' organisation or company organisation, are members of KADIN. This Law also stated that KADIN aimed to provide guidance, information, consultation, and advocacy for Indonesian employers. The goal is to create a strong and highly competitive Indonesian business world that is based on the benefits of national resources.

Article 11 of the Law No. 1/1987 regulates the distribution of roles between KADIN, corporate organisations (such as APINDO) and the other employers' organisations. The other employer organisation deals with sectoral matters. The other employers' organisations address common aspirations in their sectoral issues while KADIN deals with cross-sectoral issues based on the principle of equality.

In representing employers fighting for wage-related policies, the Chamber of Commerce has 
the regulatory power to appoint an employers' organisation that sits on the Wage Council. Presidential Decree No. 17 of 2004 concerning the Wage Council states KADIN is entitled to designate the representative of employers organisation within the Wage Council.

Based on Government Regulation No. 8/2005 on Working Procedures and Organisational Structure of Tripartite Cooperation Institutions, KADIN also has the authority to appoint an employers' organisation to sit within the Tripartite Cooperation Institution. The Tripartite Cooperation Institution (LKS Tripartite) is a forum for communication, consultation and deliberation on worker matters whose members consist of elements from employers' organisations, trade unions, and the government.

\subsubsection{Asosiasi Pengusaha Indonesia (APINDO, Association of Indonesian Employers)}

APINDO was established on 31 January 1952 and known as Badan Permusyawaratan Sosial Ekonomi Pengusaha Seluruh Indonesia (PUSPI, All Indonesian Entrepreneurs of Consultative Agency for Socio-Economic Affairs). In 1985, the second general meeting in Surabaya changed PUSPI to APINDO.

According to the APINDO website, APINDO's focus points are the struggles of workers and issues of industrial relations that emerged following Indonesian independence. In the postindependence era, workers demands for better employment protection sparked the emergence of labour-related problems involving workers and employers. APINDO was established to deal with this situation, as a communication forum of employers in solving worker and industrial relations problems. At its inception, APINDO was established as a tool of struggle for employers in the face of industrial conflicts, especially wage-related struggles by workers. APINDO also has a mandate from KADIN to represent the interest of employers in various industrial institutions.

This objective was affirmed in Musyawarah Luar Biasa (Munaslub, the Extraordinary National Congress), which resulted in the Articles of Association and the bylaws in February 2004. The Articles of association referred to the shape and nature of APINDO as "a unified, independent, and accountable organisation of Indonesian employers [with] a special activity specifically addressing the field of industrial relations/employment."

APINDO's article of association and bylaws states three organisational goals for APINDO namely: 1) creation of a socio-economic level; 2) creation of a conducive business climate; and 3) creation of harmonious industrial relations. The third goal reflects that APINDO also adopts the 
values of Pancasila industrial relations in their organisation.

APINDO members are registered companies, such as Badan Usaha Milik Negara (BUMN, owned-states enterprises), Badan Usaha Milik Daerah (BUMD, provincial-owned enterprises), Private National, Foreign Private, Cooperative and Small-medium enterprises companies. As well as the Wage Council, APINDO has three level of governance structures; the national (DPN APINDO), Provincial (DPP APINDO), and District/City levels (DPK APINDO). APINDO also has a representative its level of Wage Council.

\subsubsection{The employers in politics and government}

Some employers who are in the stewardship of KADIN and APINDO, or who are not the managers of the two organisations, are directly involved in politics by joining political party boards. Others have succeeded in positions within government and parliament.

\subsubsection{KADIN and APINDO committees in politics and government}

Some employers who currently hold management positions within APINDO and KADIN also occupied political positions:

a. Jusuf Kalla was the Vice President of the Republic of Indonesia for two periods: 2004-2009 with President Soesilo Bambang Yudhoyono, and 2014-2018 with President Joko Widodo. He, previously, appointed as minister in several governments: as Coordinating Minister for Welfare (2001-2004); and Minister of Trade and Industry (1999-2000). Jusuf Kalla is also chairman of the Golkar Party in the period 2004-2009. Within APINDO, Jusuf Kalla is currently the Honorary Chairman.

b. Sofyan Wanandi was the Chairman of APINDO between 2008-2014. In November 2014 he resigned as Chairman to take up an appointment as the Chief of the Expert Team of Vice President Yusuf Kalla.

Sofyan has been in politics since the New Order era, a close business associate of Suharto, and he led some companies belonging to the TNI. He was a member of the House of Representatives in the 1970s. His current position in APINDO is as the Chairman of the Advisory Council.

c. Arifin Panigoro is a member of the APINDO Advisory Board. He was the Chairman of the 
PDIP faction in the House of Representatives 2002-2003 but later resigned and founded the Indonesian Democratic Party of Struggle.

d. Chaerul Tanjung is a member of the APINDO Consideration Board at the time of this research. $\mathrm{He}$ is the eleventh richest person in Indonesia according to Forbes Magazine, 2010. He became Coordinating Minister of Economic Affairs in the era of Soesilo Bambang Yudhoyono. His companies include Bank Mega, Detikcom, TRANSTV, TRANS7, TRANS STUDIO (Bandung and Makassar), BSM (Bandung Super Mall), Carrefour, PT Mahagaya Perdana, and CT Global Resources.

e. Oesman Sapta was Vice Chairman of the MPR RI between 1999-2004 and 2014-2018. He is also chairman of DPD RI at the time of this research. He has been Chairman of a number of parties, namely the Regional Unity Party (2002-2004) and now the Hanura Party. At APINDO, Usman Sapta is a member of the Advisory Council.

f. Sharif Cicip Sutardjo is the current Chair of the Advisory Board of KADIN. He has been Minister of Fisheries and Marine Affairs (2011-2014) and Vice Chairman of the Golkar Party.

g. MS Hidayat is the Chairman of the current KADIN Advisory Council and Chairman of Kadin 2003-2010. In Government, MS Hidayat has served as Minister of Industry between 2009-2014.

h. Sandiaga S. Uno is Vice Chairman of KADIN for UMKM, Cooperative and Creative Industries. Currently he is also Vice Governor of DKI Jakarta Province.

i. Bambang Soesatyois. A Golkar Party politician who is currently Chairman of the House of Representatives. In KADIN he served as Deputy Chief of Inter-Institutional Relations.

\subsubsection{Non-organisation employers in government and politics}

The employers who are not currently sitting in the stewardship of APINDO and KADIN but occupy political positions include the following:

a. Rusdi Kirana is an airline owner of Lion Air, the airliner with the largest number of aircraft in Indonesia. He is now a member of the Presidential Advisory Council. Rusdi joined Partai Kebangkitan Bangsa (PKB, the Awakening Nation Party) in 2014 and soon became Vice Chairman. 
b. Fadel Muhammad is the President Commissioner of several international companies, such as: PT Arco Chemical Indonesia; PT Dowell Anadrill Schlumberger Indonesia; PT Gema Baker Nusantara; PT Gema Sembrown; and PT Nesic Bukaka. He has been Governor of Gorontalo (20012006; 2006-2009); Minister of Marine Affairs and Fisheries (2009-2011); and a Member of Parliament (2014-2018). Fadel was Vice Chairman of the DPP Golkar Party (2009-2014, 20142018).

c. Susi Pudjiastuti is Minister of Marine Affairs and Fisheries in the Government of Joko Widodo. He is the company owner of PT ASI Pudjiastuti Marine Product and the airline Susi Air.

d. Andi Amran Sulaiman was the Minister of Agriculture during the Government of Jokowi and is the company owner of 14 companies in a variety of fields, including: pesticide production, palm oil, sugar, cement distribution, gold mining, and gas stations.

e. Rahmad Gobel is the company owner of Gobel Group, a holding company that oversees a number of companies, including the largest electronics company PT Panasonic Manufacturing Indonesia. He was Minister of Commerce between 2014-2015.

f. Rini Soemarno was the Minister of Industry and Trade (2001-2004) and the Minister of StateOwned enterprises (2014-2019). She was the President Director of PT Astra International between 1998-2000; the President Director of PT Semesta Citra Motorindo between 2000-2001; and the President Director of PT Kanzen Motor Indonesia in 2005.

g. Dahlan Iskan is the company owner of media giant Java Pos Group and was Minister of SOEs between 2011-2014.

h. Abu Rizal Bakri is the company owner of Bakrie Group and was Indonesia's richest man in 2007 according to Forbes Asia magazine and Southeast Asia's richest man in 2008 according to Globe Asia magazine. Bakri has held a position in the Indonesian presidential cabinet twice; has been the Coordinating Minister for the Economy and Coordinating Minister for People's Welfare in the government of Susilo Bambang Yudhoyono. He has been a two-period general chairman of the Golkar Party, the second largest party in Indonesia.

The government official with a business background, often called on in employment issues, was Jusuf Kalla, Vice President of the Republic of Indonesia. In July 2017, Jusuf Kalla, Minister of Manpower, Hanif Dhakiri, and West Java Governor, Ahmad Heryawan, held a meeting to determine the minimum wage of the garment sector. The meeting resulted in the decision of the 
provincial minimum wage specific to garment-sector. According to the trade unions, they did not find any government regulation for the provincial minimum wage specific to garment sector. This meeting had made the garment workers' wage were lower than the provincial minimum wage (Agustine, Bisnis, 2017).

Employers often use the various spaces that have been provided by the state to influence minimum wage policy. The spaces were more open to employers than to workers. In comparison to many employers who hold government positions, there was only one minister that came from trade unions. The name of the minister was Jacob Nuwa Wea from Konfederasi Serikat Pekerja Indonesia (KSPI, Confederation of Indonesian Trade Union). He held a position as the Minister of Manpower between 2001-2004.

Employers also had more access to political positions that make it possible to influence policies favourable to their interests. In other words, the employers were less structurally constrained within the space that was provided by the state.

\subsection{Summary: Part one}

Jessop (1990) uses the Strategic Relational Approach to assess how the role of the agency, such as workers, employers and governments, or the Wage Council, are limited by the structure of higher legislations and other structures within the state. The amount of the minimum wage that is produced in the Wage Council is limited by a higher structure, i.e. policy-makers who have the authority to set minimum wages. Also, the amount of minimum wage that is produced by the agencies in the Wage Council can be limited in the space of regulations issued by the Ministry of Manpower.

Workers realise the limits of structures provided by the state. Workers also recognise that the state processes, which Jessop (1990) called strategic selectivity, affect the capitalist economic system. The system is not neutral, although it provides equal opportunities to agencies. For example, in the Wage Council, workers and employers are able to represent their groups. But the decisions in the Wage Council tend to align with the interests of employers.

Therefore, workers recognize the need to develop a strategy beyond the Wage Council; such as judicial reviews and strikes. Firstly, the judicial review aims to change the existing labour laws and regulations. Secondly strikes aim to press the government and employers. Based on the various workers' strikes conducted between 2011-2017, the amount of mass is crucial to the success of a strike. The success of workers to strike is also strongly influenced by how many workers are 
members of the union. Here, the state and employers are also concerned to reduce trade union membership numbers. The State issued several labour policies such as apprenticeship systems, contracts and outsourcing that do not allow workers to join trade unions. This strategy is strongly supported by employers. The employers have benefited from the flexible labour system. They can control the number of workers in accordance with their production.

Employers have greater ability to influence minimum wage policy. According to Miliband, one method to see how the employers' influence policies is to examine the background of government officials. Applying the Miliband method, it can be confirmed that most government officials are business people.

The core countries, who are the majority shareholders in International financial institutions, affects Indonesia through various financial assistance programmes. Particularly, in times of economic crisis. The state also tends to adopt the requirements required by international capital into various regulations concerning the minimum wage.

\section{Part two: Discussion}

This section will outline the main findings. The theoretical framework is used to help discuss the questions. Based on the background and findings chapters, the role of the international market is essential in the relationship among the workers, the employers and the state. Therefore, this chapter will begin with a discussion of international influences and end with a summary of this section

\subsection{The influence of core-countries' interests on wage policy in Indonesia}

Based on world-systems analysis, in the context of the international division of labour, Indonesia is a semi-periphery country. One characteristic of the semi-peripheral state is its labour-intensive industrial character, although Indonesian industry is beginning to be dominated by capital-intensive industries. Foreign capital enter Indonesia, building factories that absorb a lot of manpower to produce semi-finished goods and finished goods produced by labour-intensive and low-techs industries for export to developed countries.

After the Second World War, the world's financial institutions played a significant role in organising the international division of labour and maintaining the international division of labour. These international financial institutions are located at world and regional levels. Nevertheless, the largest shareholder of these international financial institutions remains the core countries. 
The effort to include Indonesia in the international division of labour has not been a simple process. Since Indonesian independence in 1945, core countries have tried various ways, including those that are economical and also through armed violence using the military in Indonesia. Coercion through conflicts took place in 1965. Core countries took advantage of the domestic situation in Indonesia, which had been experiencing various crises, both economic and political. These crises were the effect of President Sukarno's desire to bring the territory of West Papua under Indonesian rule, and the conflict with Malaysia. The crises were also caused by the internal political conflict of Indonesia, between the PKI and Masyumi, NU and also the military. Economically, when crisis occurs, and the state receives assistance from international financial institutions, the IMF also tends to offer the state to reform the structure of its legislation. Especially laws that are considered a hindrance to investment and threaten profits, such as investment laws and minimum wages.

The work of the IMF in Indonesia ended in 2003. The ADB continues to facilitate the core countries' interests to create a conducive business climate for foreign investment through the Development Policy Support Programme (DPSP). The ADB is concerned that Indonesia is more conducive to foreign investment. As reported by the ADB, the DPSP programme has resulted in some significant advances in improving investment climate objectives. The report found three significant obstacles, such as the issue of governance and institutions. Included in the issues of governance and institutions are the clarity and effectiveness of regulations, the flexibility of the labour market, and the existence of an educated and skilled workforce.

These findings align with Wallerstein's analysis, that core countries lead weaker countries through international policies and urge weaker nations, either semi-periphery or peripheral, to follow their rules.

An aspect to note about the world-system analysis is that although the strategic relational approach built by Jessop can also be used to analyse how the international capital influences the role of the state, the world-system analysis provides a more detailed analysis of the world-system. For example, it can explain the hegemony of core countries in minimum wage policy setting. If using Jessop's approach the focus will necessarily be on how the state makes a number of choices against the pressures exercised by international capital forces on minimum wage policy. Unlike the world-system analysis that will focus more on how hegemony occurs and influences wage policy. 


\subsection{Workers' struggles and employers}

The weakness of developed countries within the world-system is not the only factor affecting labour policy and remuneration. Workers' and employers' struggles, both through trade unions and employers' associations, attempt to influence political parties; engage in government; and have a significant impact on the government's policy on wages and wage rates. Workers and employers actively organise themselves to fight for their interests in wage policy-making.

The instrumentalist approach sees the state as the instrument of the dominant capitalist class. The capitalist class influences the power of the state to impose its interests on other classes, in addition to being directly involved in government. They also use a filtering mechanism to ensure the ranks of the state elite are individuals who accept capitalism and support capitalist interests.

Ralph Miliband and instrumentalists more generally are correct that the state is not a space open to class participation. The findings chapter of this thesis revealed the number of business elites who are in government positions and administrators of political parties. Employers also have some crucial positions in the management of employers' organisations of APINDO and KADIN, and others are the wealthiest employers who are not the managers of the organisation.

The number of employers' involved in this government differs significantly from the conditions of their opponents - the workers. From the time of Suharto to the New Order, Jacob Nuwawea was the only minister with a social background as a worker. Yakob Nuwawea is the chairman of one of the trade unions. He is also a PDIP officer. At the time of President Megawati Sukarnoputri, Jacob Nuwawea became the Minister of Manpower.

Based on the instrumentalist approach, the reasons as to why wage policy tends to be procapitalist can be investigated through employers' involvement in government. These influential factors can also be examined from the employers' involvement in parliament or political parties.

Other facts, which will be reviewed later, especially in some cases where government decisions differ from employers' aspirations in setting minimum wages cannot be explained by the instrumentalist approach.

\subsection{The role of states to enforce conflict and continue capitalism}

From Poulantzas' structuralist perspective (1978), the state is a superstructure that reflects the conditions of the basic structure. In the capitalist economic system, the state is capitalist. But as the 
superstructure, the state is not a passive mirror, which is merely a reflection of the economic conditions. The state is an active mirror, in the sense that the state plays a role in maintaining the capitalist system in situations of crisis. The crisis experienced by capitalism may be a fall in profit rates or a conflict between the social classes.

In investigating whether the state is capitalist or not, the structuralists examined the policies enacted by the state. In the context of wage policy, this research examined the relationship between various wage regulations with the interests of perpetuating capitalism. The regulation was designed to moderate class conflicts. The regulations did not develop into classes conflict that might lead to the destruction of the capitalist system. The regulation also designed the accumulation of profit, as a condition of capitalism continuing in the crises.

Some state policies respond to workers' demands to raise wage rates but do not suppress capitalist profit levels in times of a sluggish economy. Among them is the wage policy that was published after Law 13/2003 was published and confirmed by Government Regulation No. 78 of 2015 and the decree of the Minister of Manpower concerning wages,

The formula for the increase in the wage of workers used the formula UMP $(t+1)=U M P t$ $\mathrm{x}$ (inflation rate + economic growth rate) and aimed to prevent welfare levels from falling to the previous level whilst not eroding the profit rates of the employers.

On the other hand, the state seems to provide space for workers and employers to fight for their own interests in wage rates through the Wage Council. But the decision of the Wage Council is only a recommendation to the governor. The governor ultimately decides the minimum wage. In making decisions the governor is obliged to use the decisions of the Minister of Manpower on the rate of inflation and economic growth (based on BPS data) when increasing wages.

Whenever employers and workers use the Wage Council to reach an agreement on wages, the final decision is in the hands of the government. The Wage Council is only a channel in which the conflict between workers and employers can take place in moderate constitutional spaces.

The increase in the minimum wage that is approved by the governor could be different from the recommendations of workers and employers in the Wage Council. This distinction is evidence that the state may make a different decision, even if it must be against the capitalist. The state decision is not motivated by its alignment with the workers, but its role in maintaining the sustainability of the capitalist system. 


\subsection{Strategic relational approach: Agency that fight within the available structure}

Jessop offers a strategic relational approach to connect the gap between structuralist and instrumentalist views. It places structure and agency as two dialectical factors in shaping the role of the state. In the context of the remuneration of these available structures, there are two levels, namely: the institutions provided by the state for tripartite and legal-formal negotiations; and the structure of the state itself.

In the wage policy decision-making, we find that the struggle of workers and employers through their organisations has spawned some policies in the form of laws, Government Regulations, Presidential Decrees and Ministerial Decrees. Conversely, the policies of the state in responding to the struggle of workers and employers is a new space for the struggle of workers and employers in the next stage.

The struggle of workers and employers in lobbying and pressuring the government has led to the regulation of the Wage Council. In the Wage Council, workers and employers are fighting for the appropriate wage levels to suit their interests. Decisions within the Wage Council are not outcomes, but rather recommendations to the Governor. The Governor's Decree on Minimum Wages is subject to the Decree of the Minister of Manpower. The Decree of the Minister of Manpower itself is made under the labour law. To ensure that the Manpower Act is more in favour with its interests, the workers also use the Constitutional Court to conduct judicial reviews of articles considered to be detrimental to their interests.

It appears that wage rates are the result of the fighting of agents, i.e. workers, employers, and government apparatuses in various institutions governed by the Act. The various regulations and institutions of the existing state ensure that the struggle between interest groups takes place without endangering capitalism as a prevailing economic and political system.

This debate also occurs outside of the official institutions offered by the state for industrial relations. Workers are aware that the spaces provided by state institutions, whether tripartite, bipartite or judicial, are not sufficient to fight for minimum wages. Not all unions can be members of the Wage Council. The state made a selection mechanism. There are only large unions which have members that can meet the required level of qualifications. Workers have also not been able to enter into state policy-making structures, such as parliament or the Ministry of Manpower. Therefore, workers feel that they need to take advantage of the democratic space provided by the state, by conducting demonstrations. To contrast, during the authoritarian Suharto period 
democracy was considered a luxury. The government banned strike and intimidated the trade unions members.

To utilise the space, workers then organised themselves; building alliances with other unions to have sufficient strength to influence their minimum wage decisions and policies. The actions that occurred between 2011-2014 are evidence of how the mass action can affect the amount of minimum wage. Even though, the amount of minimum wage was decided by the Wage Council the following year, the country changed its strategy and again succeeded in reducing the workers' plans.

Jessop's approach is the appropriate analytical tool to look at the overall role of agents (workers, employers, and the government apparatus) within the institutional spaces and mechanisms provided by the state. The space and mechanism itself is available due to the accumulation of struggles of agencies that clash with interests. .

\subsection{Summary of part two}

As noted above, it appears that none of the approaches mentioned, the instrumentalist, structuralist, world-system analysis, nor the strategic-relational, contribute to fully understanding the role the state plays in determining wage levels. International interests, the struggles of workers and employers, as well as state institutions with authority over wage policy, contribute to the determination of wage levels. The proportion of influence of each of these elements is dynamic, varying from time to time. There was a time when workers' pressures contributed to policy changes. There was a period when the lobbying of business people became the most influential factor in policy. Also, there have been times when wage policies are concerned with the interests of international capitalists through the governments of developed countries and supra-state structures. 


\section{Chapter 5: Conclusion}

In conclusion, two points can be drawn from this study. The first is the role of the state in the minimum wage decision-making process. Second this thesis demonstrates how to apply the theories that analyse the role of the state in social policy-making. These points will be discussed in sequence below. In closing, the study will also provide recommendations for related future studies.

The minimum wage rate is the result of demands and pressure from workers and employers. Minimum wage policies may change in form, content and operation depending on how these forces take effect within the spaces provided by the state. Employers are always trying to depress workers' wages to maximise their profits. They do this by agreeing to policies that are in line with their interests and by rejecting policies that will disadvantage them. The workers realise that the minimum wage can only increase by reducing the profits of the employer and without sacrificing other workers through layoffs or other wage cuts.

As stated by Poulantzas (1978) and Jessop (1990), the state has a role to ensure that the struggle between these interest groups takes place without harming capitalism as the prevailing system. The role of the government apparatus, both at the national and regional level, can be seen from the various rules and legislation. At the national level, the result of regulations may be enacted by the Ministry of Manpower in the form of ministerial regulations, ministerial decrees, presidential decisions and legislative. These regulations enacted by legislators directly control workers and the governing of society in general.

Another factor that influences the government's alignment with the capitalist system is the background of its government officials. As Miliband has said, one method of identifying class dominance in the state is by studying the background of government officials. In this case, the government officials are mostly business people.

Historically, the interests of core countries have also significantly influenced the emergence of politico-bureaucrats in Indonesia and those employers who have close ties with government officials because of their commercial interests. When the reformers opened opportunities for them to entry government and political structures, employers and business people took the chance to enter government structures or parliament to influence policy.

If the employers, with better access and facilities responds to the opportunities offered by the state by entering into government or political structures, the workers take up democratic spaces, 
such as tripartite institutions, the judiciary and strike action. Sometimes, workers' struggles result in a victory for higher wages; more commonly workers experience defeat. Organizing and alliances between trade unions as well as with other groups make the workers' efforts to influence wage policy more effective.

Various labour policies that are issued by the government cannot be separated from the influence of the interests of core countries. The Indonesian government is encouraged to enact multiple policies when a crisis occurs, including taking on debt and its associated obligations. Flexible labour and cheap wages are always written into agreements with international or regional agencies. Therefore, the minimum wage policy is still subject to the policies of international and regional financial institutions.

Analysis of the role of the state in minimum wage policy setting is not a natural process, and there are many influential factors. Therefore, some theories about the capitalist state and the worldsystem can be used together. As mentioned in the previous section, strategic relational approaches can be used to study the impact of international pressure and the demand for minimum wage policies in a country. But world-systems analysis may reveal more details about the state's position in the international division of labour and also how the hegemonic processes that impact semiperipheral and peripheral states came about.

For future study, similar research may consider the involvement of workers in parliament. The absence of such considerations is a limitation of this study. Some trade union members have held, or hold, political positions in government at both regional and national levels. How they contribute to the improvement of the wage decision-making process, and how effective they have been in occupying political positions, is worth studying.

Finally, as mentioned earlier, this study intends to contribute to information for use by unions to identify possible strategies for demanding improvements to the wage system. Based on the results of this study, the struggle to improve the calculation of minimum wages or improvements in the welfare of workers, in general, cannot expect to use one strategy in isolation. Instead, the struggle must maximise the spaces provided by the state, whether related to the welfare of workers directly or indirectly. 


\section{References}

Ábalos, J. (1997). Marx’s Theory of Wages. International Journal of Political Economy, 27(4), 96114. Retrieved from http://www.jstor.org/stable/23317518

Achmad, A. (2017, February 7). 4 Gugatan uji materi kandas, PP pengupahan tetap berlaku [The four judicial review proposals failed, the government regulation of wages still prevail]. Hukum Online. Retrieved from http://www.hukumonline.com/berita/baca/lt5899424c31b4b/4gugatan-uji-materi-kandas--pp-pengupahan-tetap-berlaku

Agba, A., \& Ushie, E. (2013). Wage differentials and industrial disputes in Nigerian hospitals. Journal of Business and Management (IOSR), 11(5). Retrieved from http://www.iosrjournals.org/iosr-jbm/papers/Vol11-issue5/A01150112.pdf

Anderson, B. (2006). Imagined Communities: Reflection on The Origin and Spread of Nationalism. Revised edition. London, England: Verso.

APINDO, \& ILO. (2015). A guideline for employers: Preparing our youth today for tomorrow's workforce. Asosiasi Pengusaha Indonesia [APINDO, Indonesia Employers' Association] \& International Labour Organisation (ILO). Retrieved from https://apindo.or.id/userfiles/publikasi/pdf/Pedoman_Pengusahan__Pemagangan_Apprenticeship_Guideline_-_English.pdf

Aspinall, E. \& Fealy, G. (Eds.). (2010). Soeharto's New Order and its legacy: Essays in honour of Harold Crouch. Canberra, Australia: ANU E Press. Retrieved from http://epress.anu.edu.au/soeharto_citation.html

Azizi, A., Margaritma, E., \& Widodari, G.. (2017, July 30). Tulisan bersama rangkaian aksi buruh 2012 [A joint writing of the labour strike 2012]. KOMA UGM. Retrieved from http://komapugm.org/kajian-dan-opini/tulisan-bersama-rangkaian-aksi-buruh-2012-fenomena- 
grebek-pabrik

Badan Pusat Statistik (BPS). (2014). Statistical Yearbook of Indonesia 2015. Jakarta, Indonesia: BPS. Retrieved from https://www.bps.go.id/index.php/publikasi/1045

Badan Pusat Statistik (BPS). (2016). The overview of poverty in Indonesia on March 2016. Jakarta, Indonesia: BPS Retrieved from https://www.bps.go.id/brs/view/id/1229

Badan Pusat Statistik (BPS). (2017). BPS: Jumlah Penduduk Bekerja Naik 6.13 Juta, Pengangguran Turun 0.28 persen. Sekretariat Kabinet Republik Indonesia [Governmental Cabinet Secretary of Republic of Indonesia]. Jakarta, Indonesia: BPS. Retrived from http://setkab.go.id/bps-jumlah-penduduk-bekerja-naik-613-juta-pengangguran-turun-028persen/

Baldock, J., Mitton, L., Manning, N., \& Vickerstaff, S. (Eds.). (2007). Social policy (3 ${ }^{\text {rd }}$ ed.). Oxford, England: Oxford University Press.

Barrow, C. W. (1993). Critical theories of the state: Marxist, Neo-Marxist, Post-Marxist. Madison, WI: University of Wisconsin Press.

Barrow, C. (2002). Paradigm lost: State theory reconsidered (ebook). In S. Aronowitz, \& P. Bratsis (Eds.), (pp. 23). Minneapolis, MN: University of Minnesota Press.

Basu, T. (2017, June 9). Asian Development Bank at 50 and Japan's puzzle. East Asia Forum. Retrieved from http://www.eastasiaforum.org/2017/06/09/asian-development-bank-at-50-andjapans-puzzle/

Bayliss, K., Fine, B., \& Robertson, M. (2016). The role of the state in financialised systems of provision: Social compacting, social policy, and privatisation (Working papers No. 154). Financialisation, Economy, Society \& Sustainable Development (FESSUD) Project. London, England: FESSUD. Retrieved from http://eprints.soas.ac.uk/22710/1/Role-of-the-stateworking-paper-154.pdf 
Becker, S., \& Bryman, A. (Eds.). (2005). Understanding research for social policy and practice: Themes, methods and approaches. Bristol, England: The Policy Press.

Beerkens, E. (n.d.). The student movement and the rise and fall of Suharto. Retrieved from http://www.universityworldnews.com/filemgmt_data/files/The $\% 20$ rise $\% 20$ and $\% 20 \mathrm{fall} \% 20$ of \%20Suharto.pdf

Belser, P., \& Rani, U. (2015). Minimum wage and inequality. In institution and inequality: Building just societies in the 21st century. J. Berg (Ed.). Geneva, Switzerland: Edward Elgar Publishing.

Betterwork (n.d.). Social security and healthcare security (guideline). Geneva, Switzerland: Betterwork. Retrieved from https://betterwork.org/in-labourguide/?page_id=617

Bonoli, G. (2003). Social policy through labor markets: Understanding national differences in the provision of economic security to wage earners. Comparative Political Studies. 36(9), 10071030. doi:10.1177/0010414003257099.

Botz, D. (2001). Made in Indonesia: Indonesian workers since Suharto. Cambridge, England: South End Press.

Bourchier, D. (2015). Illiberal democracy in Indonesia: The ideology of the family state. London, England: Routledge Curzon.

BPJS Ketenagakerjaan imbau perusahaan bayar upah sesuai ump [BPJS ketenagakerjaan appealed to company paying wages according to provincial minimum wage]. (2017, June 22). Metro TV News. Retrieved from http://ekonomi.metrotvnews.com/mikro/5b2joxVb-bpjsketenagakerjaan-imbau-perusahaan-bayar-upah-sesuai-ump

Braun, V., \& Clarke, V. (2008). Using thematic analysis in psychology. Qualitative Research in Psychology, 3(2), 77-101. doi: 10.1191/1478088706qp063oa 
Brassard, C. (2004). Wage and labour regulation in Vietnam within the poverty reduction agenda. policy \& society, 23(2), 49-77. doi: 10.1016/S1449-4035(04)70032-6

Buruh serahkan gugatan judicial review PP pengupahan ke MA. [Labour Submit the judicial review proposal of the government regulation on the wages to the Supreme Court]. (2015, December 12). Kabar Buruh. Retrieved from http://kabarburuh.com/2015/12/10/buruh-serahkangugatan-judicial-review-pp-pengupahan-ke-ma/

Cahyono, E. (2003) Perburuhan dari masa ke masa: Jaman kolonial Belanda sampai Orde baru [The history of workers: From Dutch colonization to the New Order]. In D. Soegiri \& E. Cahyono (Eds), Gerakan Serikat Buruh: Jaman Kolonial Hindia Belanda hingga Orde Baru [Trade Unions Movement: From the Dutch Colonization to New Order] (pp. 6-31). Jakarta, Indonesia: Hasta Mitra.

Cappelletti, M. (1989). The judicial process in comparative perspective. London, England: Clarendon Press-Oxford.

Carnoy, M. (1984). The state and political theory. New Jersey, NJ: Princeton University Press. Retrieved from http://www.jstor.org/stable/j.ctt7zvcd1

Chase-Dunn, C. \& Grimes, P. (1995). World-system analysis. Annual Review of Sociology, 21, 387417. Retrieved from http://links.jstor.org/sici?sici=03600572\%281995\%2921\%3C387\%3AWA\%3E2.0.CO\%3B2-D

Chris, O. (2017). The changing role of the state in industrial relation and social protection. BVIMSR's Journal of Management Research, 9(1). Lagos, Nigeria: University of Lagos. Retrieved from http://www.bvimsr.com/documents/publication/2017V9N1/2.pdf

Colepicolo, E. (2015). Information reliability for academic research: Review and recommendations. New Library World, 116(11/12), 646-660. Retrieved from https://doiorg.helicon.vuw.ac.nz/10.1108/NLW-05-2015-0040 
Corbyn, C. (2014). Organised labour in the 2014 Indonesian presidential election (Master's thesis, Parahyangan Catholic University, Bandung, Indonesia). Retrieved from http://1073zb3xfs20yv98x228do7r.wpengine.netdna-cdn.com/wpcontent/uploads/2016/03/S39_CORBYN_Charlotte_WJFS_Labour-Politics-Elections.pdf

Cunningham, W. (2007). Minimum wages and social policy: Lesson from Developing Countries. Washington DC, WA: The World Bank. Retrieved from https://openknowledge.worldbank.org/handle/10986/6760

Dieu, D.Q. (2012). A Study on trade unions strategies on minium wage determination and setting in Vietnam. Vietnam General Confederation of Labour Institute for Workers and Trade Unions. Hanoi, Vietnam: International Labour Organisation (ILO). Retrieved from http://www.ilo.org/wcmsp5/groups/public/---ed_dialogue/--actrav/documents/meetingdocument/wcms_209160.pdf

el-Ojeili, C. (2014). Reflections on Wallerstain: The modern world-system, four decades on. Critical Sociology, 41(4-5), 679-700. doi:10.1177/0896920513497377

Esping-Andersen, G. (1990). The three worlds of welfare capitalism. Cambridge, England: Polity Press.

Falkner, G. \& Talos, E. (1994). The role of the state within social protection. West Europen Politics, 17(3). Retrieved from http://www.informaworld.com.helicon.vuw.ac.nz/smpp/title $\sim \mathrm{db}=$ all $\sim$ content $=\mathrm{t} 713395181 \sim \mathrm{tab}$ $=$ issueslist

Fapohunda, T. (2012, January). Comparative analysis of wage determination in unionized and nonunionized organisations in Nigeria. International Research Journal of Educational Research,3(1). Retrieved from https://www.interesjournals.org/articles/comparative-analysisof-wage-determination-in-unionized-and-nonunionized-organisations-in-nigeria.pdf 
Farid, H. (2005). Indonesia's original sin: mass killings and capitalist expansion, 1965-66, InterAsia Cultural Studies, 6(1), 3-16. Retrieved from http://dx.doi.org/10.1080/1462394042000326879

Flohr, M. \& Harrison, Y. (2016). Reading the conjuncture: state, austerity, and social movements, an interview with Bob Jessop. Rethinking Marxism, 28(2), 306-321. doi:10.1080/08935696.2016.1163988

Ford, M. (2003). NGO as outside intellectual: A history of non-governmental organisation' role in the Indonesian labour movement. (Doctoral thesis, School of history and Politics, University of Wollongong New South Wales, Australia). Retrieved from http://ro.uow.edu.au/theses/150

Ford, M. (2004). A Case for convergence? Indonesian labour politics, 1973-1998. The Australasian Political Studies Association Conference, 29 September - 1 October 2004. Adelaide, Australia: University of Adelaide. Retrieved from https://www.adelaide.edu.au/apsa/docs_papers/Others/Ford.pdf

Gerakan buruh independen, tak ditunggangi parpol (Labour movements is independent, they are not ridden by the political party). (2012, December 4). Berita Satu. Retrieved from http://sp.beritasatu.com/home/andi-gani-gerakan-buruh-independen-tak-ditunggangiparpol/27747

Goldfrank, W. (Ed.). (1979). The world-system of capitalism: past and present. London, England: Sage Publications.

Goldfrank, W. (2000) Paradigm regained? The rules of Wallerstein's world-system method. Journal of World-System Research, 11(2), 150-194. Retrieved from http://jwsr.pitt.edu/ojs/index.php/jwsr/article/view/223/235

Gough, I. (2000). Global capital, human needs and social policies. New York, NY: Palgrave. 
Gough, I. (2013). Social policy regimes in the developing world. In P. Kennet (Ed.). A handbook of comparative social policy (pp. 205-224). Cheltenham, England: Edward Elgar Publishing. Retrieved from http://eprints.lse.ac.uk/51023/1/Gough_social_policy_regimes_2013.pdf

Griffith-Jones, S. (n.d.) Governance of the World Bank. London, England: Departement of International Development (DFID). Retrieved from https://www.ids.ac.uk/files/GovernanceWorldBank.pdf

Grindle, M. (2010). Social policy in development: Coherence and cooperation in the real world (DESA Working Paper No 98.ST/ESA/2010/DWP/98). Geneva, Switzerland: United Nation. Retrieved from http://www.un.org/esa/desa/papers/2010/wp98_2010.pdf

Hadiz, V. (1997). Workers and the state in New Order Indonesia. London, England: Routledge.

Hadiz, V. (2000) Globalization, labour and the state: the case of Indonesia. Asia Pacific Business Review, 6(3-4), 239-259. doi: 10.1080/13602380012331288552.

Hadiz, V. (2003). Coolie labour in colonial indonesia: A study of labour relations in the outer islands, c. 1900-1940 (Book Review). The Journal of Asian Studies, 62(3), 1011-1012. Retrieved from http://www.jstor.org/stable/3591923

Hadiz, V. (2006). The Left and Indonesia's 1960s: the politics of remembering and forgetting. Inter-Asia Cultural Studies, 7(4), 554-569. doi:10.1080/14649370600982883

Handoyo. (2017, February 06). Empat uji materi PP pengupahan kandas di MA [The four of judicial review of the government regulation on the wages were aground in the Supreme Court]. Kontan. Retrieved from http://nasional.kontan.co.id/news/empat-uji-materi-pp-pengupahankandas-di-ma

Harvey, D. (2010). The Enigma of Capital: And the Crisis of Capitalism. London, England: Profile Books. 
Hayden, P. \& el-Ojeili, C. (2006). Critical Theories of Globalization. New York, NY: Palgrave.

Heintz, J. \& Lund, F. (2012). Welfare Regimes and Social Policy: A Review of the Role of Labour and Employment(Research Paper No. 2012 (4)). Geneva, Switzerland: UNSRID. Retrieved from: http://www.unrisd.org/80256B3C005BCCF9/ (httpAuxPages)/87D8B3F3C788D275C1257A3100440E39/\$file/Heintz\%20Lund.pdf

Hickson, J.(Producer \& Director) \& Reynolds, J. (Script editor) (1999). Indonesian in revolt: Democracy or death [Video file]. Sidney, Australia: ASIET \& ARTV. Retrieved from https://www.youtube.com/watch?v=NhYd3zmRd14

Higgott, R. \& Robison, R. (2014). Southeast Asia: essays in the political economy of structural change. New York, NY: Routledge.

Hill, H. \& Narjoko, D. (2010). Managing industrialization in a globalizing economy: Lesson from Soeharto era. In E. Aspinnal \& G. Fealey (Eds.), Soeharto's New Order and its Legacy: Essays in honour of Harold Crouch (pp. 49-66). Canberra, Australia: ANU E Press. Retrieved from http://epress.anu.edu.au/soeharto_citation.html

Hoopkins, T. \& Wallerstein, I. (1982). World-systems analysis: Theory and methodology. London, England: Sage Publications.

Human Right Watch (1994). Indonesia: the Medan demonstrations and beyond. Human Right watch Report, 6(4). Retrieved from https://www.hrw.org/sites/default/files/reports/INDONESI945.PDF

Hwan, S. (2011). Aspek hubungan perburuhan perusahaan Korea di Indonesia pada awal 1990-an: manajemen ala Korea dan wacana buruh [The aspects of labour relation of Korean enterprises in Indonesia in the early 1990s: Korean management and workers discourse]. Kyoto Review, 11. Retrieved from https://kyotoreview.org/issue-11/aspek-hubungan-perburuhan-perusahaankorea-di-indonesia-pada-awal-1990-an-manajemen-al-a-korea-dan-wacana-buruh/ 
ILO (n.d.). Minimum wages: an introduction (article). Retrieved from http://www.ilo.org/global/topics/wages/minimum-wages/WCMS_458660/lang--en/index.htm

ILO (n.d.). Ratification for Indonesia. International Labour Organisation (ILO). Retrieved from http://www.ilo.org/dyn/normlex/en/fp=NORMLEXPUB:11200:0::NO::P11200_COUNTRY ID: 102938

ILO (2015) Resolution concerning the recurrent discussion on social protection (labour protection). The general conference of the International Labour Organisation meeting, $104^{\text {th }}$ session. Retrieved from http://www.ilo.org/wcmsp5/groups/public/---ed_norm/--relconf/documents/meetingdocument/wcms_380781.pdf

IMF (2003). Letter of Intent, memorandum of economic and financial policies, and technical memorandum of understanding. Retrieved from http://www.imf.org/External/NP/LOI/2003/idn/01/index.htm

IMF (2018). IMF members' quotas and voting power, and IMF board of governors. Retrieved from http://www.imf.org/external/np/sec/memdir/members.aspx

Islam, I. \& Nazara, S. (2000). Minimum wage and the welfare of indonesian worker (Occasional Discussion Paper Series No.3). Jakarta, Indonesia: ILO

Iwamoto, K. (2018, January 30). Minimum wage politicking sting employers in Southeast Asia. Nikkei. Retrieved from https://asia.nikkei.com/Features/Asia-Insight/Minimum-wagepoliticking-stings-employers-in-Southeast-Asia?page $=1$

Jessop, B. (1990). State theory: Putting the capitalist state in its place. Cambridge, England: Polity Press.

Jessop, B. (2002). The future of the capitalist state. Cambridge, England: Polity Press. 
Jessop, B. (2003). Globalization and the national state. Lancaster, England: Lancaster University. Retrieved from http://www.comp.lancs.ac.uk/sociology/papers/Jessop-Globalization-and-theNational-State.pdf

Jessop, B. (2008). Dialogue of the deaf. Some reflections on the poulantzas-miliband debate. In P.Wetherly, C. W. Barrow \& P. Burnham (Ed.), Class, Power, and the State in Capitalist Society, (pp. 137-157). New York, NY: Palgrave Macmillan.

Jessop, B. (2013). The capitalist state: Marxist theorist and methods. Oxford, England: Martin Robertson \& Company.

Jessop, B. (2015). The state: past present and future (ebook). Cambridge, England: Polity Press.

Joedadibrata, D. (2012). A Study of the shift towards universal social policy in Indonesia (Master thesis, Institute of Social Studies, The Hague, The Netherlands). Retrieved from http://hdl.handle.net/2105/13046

Julian, B. (2012, January 23). Locating the power of labour. Inside Indonesia. Retrieved from http://www.insideindonesia.org/locating-the-power-of-labour-2

Juliawan, B. (2011). Street-level politics: Labour protests in post-authoritarian Indonesia. Journal of Contemporary Asia, 41(3), 349-370. Retrieved from http://dx.doi.org/10.1080/00472336.2011.582706

Kamaludin, A. (2015, October 27). Buruh akan ajukan judicial review aturan pengupahan [Trade unions will propose judicial review on the wages]. Kata Data. Retrieved from https://katadata.co.id/berita/2015/10/27/buruh-akan-ajukan-judicial-review-aturanpengupahan

Kerkhof, J. (2005, March) Dutch enterprises in independent Indonesia: cooperation and confrontation, 1949-1958. IIAS Newsletter, 36. Leiden, Netherland: IIAS. Retrieved from https://iias.asia/sites/default/files/IIAS_NL36_18.pdf 
Kroef, J. M. (1956). A new course in indonesia?. International Journal, 11(2), 129. Retrieved from https://search-proquest-com.helicon.vuw.ac.nz/docview/1290324354?accountid=14782

Laliberte, P. (Ed.). (2012). Social justice and growth: The role of the minimum wage. International Journal of the Labour Research, 4(1). Geneva, Switzerland: International Labour Organisation (ILO). Retrieved from http://www.ilo.org/actrav/events/WCMS_182539/lang-en/index.htm

Lane, M. (2008). Unfinished nation: Indonesia before and after Soeharto. New York, NY: Verso.

Lavalette, M. \& Mooney, G. (2000). Class struggle and social welfare. London, England: Routledge.

LBH Jakarta. (2017). Catatan akhir tahun 2010-2017 [The year-end notes 2010-2017] Jakarta, Indonesia: Lembaga Bantuan Hukum (LBH) Jakarta. Retrieved from https://www.bantuanhukum.or.id/web/catahu/

Lederman, N. \& Lederman, J. (2015). What is a theoritical framework? A practical answer. The Association for Science Teacher Education, USA. J Sci Teacher Educ, 26, 539-597. doi: 10.1007/s10972-015-9443-2

Lev, D. \& McVey, R. (Ed.). (1996). Making Indonesia. Cornell University. New York, NY: Southeast Asia Programme Publication

Lin, D. (2016). Ecological spatial regulation in China: understanding conservation from the strategic relational approach. Sociology and Anthropology, 4(8), 751-763. doi: 10.13189/sa.2016.040810.

Mack, A. (2001). Rethinking the dynamic of capital accumulation in colonial and post-colonial Indonesia: Production regulation (Doctoral thesis, Department of Economics, University of Sidney). Retrieved from https://ses.library.usyd.edu.au/bitstream/2123/498/2/adtNU20031112.09391002whole.pdf. 
Manning, C. (1993). Structural change and industrial relation during the soeharto period an approaching crisis? Bulletin of Indonesian Economic Studies, 29(2), 59-95. doi: 10.1080/00074919312331336401.

Maguire, M. \& Delahunt, B. (2017). Doing a thematic analysis: A practical, step-by-step guide for learning and teaching scholars. AISHE-J: The all Ireland journal of teaching \& learning in higher education, 9(3), 3351-33514. Retrieved from http://ojs.aishe.org/index.php/aishe$\mathrm{j} /$ article/viewFile/335/553

Mascarenhas, R. (2002). A comparative political economy of industrial capitalism. New York, NY: Palgrave Macmillan.

Masduki, T. (n.d.). Workers rights in Indonesia in the era of export oriented industry: A Background briefing. Jakarta, Indonesia: Asia Pacific Solidarity Network. Retrieved from http://www.asia-pacificsolidarity.net/southeastasia/indonesia/publications/doss 1/teten.htm.

McGinn, M. (2010). Data resources. In A.J. Mills, (Ed.), Encyclopaedia of the case study research. Retrieved from http://dx.doi.org/10.4135/9781412957397.n102.

McVey, R. (2006). The rise of Indonesian communism (first equinox edition). Singapore, Singapore: Equinox Publishing.

Menaker sayangkan jumlah buruh berserikat menurun [The Minister of Manpower said the number of workers who join trade unions is declining]. (2017, March 25). Viva. https://www.viva.co.id/berita/nasional/897985-menaker-sayangkan-jumlah-buruh-berserikatmenurun.

Millions of Indian workers strike for better wages. (2016). Aljazeera. Retrieved from https://www.aljazeera.com/news/2016/09/millions-indian-workers-strike-wages160902131706206.html. 
Minimum wage. (2013). In D. Rutherford, Routledge dictionary of economics (3rd ed.). London, England: Routledge. Retrieved from http://helicon.vuw.ac.nz/login? url=https://search.credoreference.com/content/entry/routsobk/minimum_wage/0? institutionId $=5378$.

Mizuno, K. (2005). The rise of labor movements and the evolution of the Indonesian system of industrial relations: A case study. The Developing Economies, 43(1), 190-211. doi:10.1111/j.1746-1049.2005.tb00258.x.

Mufakhir, A. (Producer). (2014). Bekasi bergerak [Bekasi workers fight back] [Video file]. Jakarta, Indonesia: LIPS Sedane \& Komunitas Perfilman Intertekstual. Retrieved from https://www.youtube.com/watch?v=dUmGr-sXGZQ

Mufakhir, A. (2016). Cases of labour right violations and harrassment of labour leaders in Indonesia (pamphlet). Kowloon, Hongkong: AMRC. Retieved from https://amrc.org.hk/sites/default/files/Cases\%20of\%20labour\%20rights\%20violations\%20in \%20Indonesia.pdf

Muncada, J.P. (2001). The labor movement: Its role and impact in the democratization of Indonesian society during the later part of the Soeharto period. Asian Studies, 37(1\&2), 54-68. Retrieved from http://www.asj.upd.edu.ph/index.php/archive/144-vol-37-nos-1-2-2001

Munck, R. (2002). Globalisation and labour: The New 'great transformation'. London, England: Zed Books, Ltd.

Mushed, M., \& Tadjoeddin, M. (2015). Political economy of the Indonesian mass killing of 19651966 (Paper No. 64878). Munich, Germany: Munich Personal RePec Archive (MPRA). Retrieved from http://mpra.ub.uni-muenchen.de/64878/

Nishimura, S. (1995). The development of Pancasila moral education in Indonesia. Southeast Asian Studies, 33(3). Retrieved from https://kyoto-seas.org/pdf/33/3/330302.pdf 
Nolte, C. \& Ghosheh, N. (2010). Working conditions laws report 2010: A Global Review. Geneva, Switzerland: International Labour Organisation. Retrieved from www.ilo.org/travail

Nordiansyah, E. (2016, February 15). Anggota serikat buruh wajib bayar iuran 1\% dari upah minimum sektoral [The member of trade unions must pay $1 \%$ of their sectoral minimum wage as membership fee] Metro TV News http://ekonomi.metrotvnews.com/read/2016/02/15/484515/anggota-serikat-buruh-wajibbayar-iuran-1-dari-upah-minimum-sektoral

Norton, A., Conway, T. \& Foster, M (2001). Social protection concepts and approaches: implication for policy and practice in international development. London, England: Overseas Development Institute (ODI). Retrieved from https://www.odi.org/sites/odi.org.uk/files/odiassets/publications-opinion-files/2999.pdf

O’Connor, M. \& Netting, F. (2011). Analyzing social policy: Multiple perspective for critically understanding and evaluating policy. New Jersey, NJ: John Wiley \& Sons.

Panitch, L. \& Gindin, S. (2012). The making of global capitalism: The political economy of american empire. London, England: Verso.

Poggi, G. (1978). The development of modern state: A sociological introduction. Stanford, England: Stanford University Press.

Praditya, I. (2016, February 2016). Bos serikat pekerja: Iuran anggota untuk organisasi [A chief of trade union: The membership fee address to organisation]. Liputan 6. http://bisnis.liputan6.com/read/2436756/bos-serikat-pekerja-iuran-anggota-untuk-organisasi

Putusan Mahkamah Agung RI No. 69P/HUM/2016 [The Verdict of the Supreme Court No. 69P/HUM/2016] (2016). Retrieved from https://putusan.mahkamahagung.go.id/putusan/downloadpdf/25a2fcd2176d9dc9f3c7ea61d90f 195b/pdf\&sa=U\&ved=0ahUKEwjujP_DreDZAhUBXbwKHUS4CnEQFggGMAE\&client=in ternal-uds- 
cse\&cx $=004086544163985272441$ :foabjjpxdue\&usg=AOvVaw2SN7Khr3sy01bp3oHjHjnX

Putusan Mahkamah Agung RI No. 67P/HUM/2015 [The Verdict of the Supreme Court No.

67P/HUM/2015] (2015). Retrieved from

https://putusan.mahkamahagung.go.id/putusan/downloadpdf/e7183dd2e018501486b9828a828

b72d7/pdf\&sa=U\&ved=0ahUKEwjujP_DreDZAhUBXbwKHUS4CnEQFggEMAA\&client=i nternal-uds-

cse\&cx=004086544163985272441:foabjjpxdue\&usg=AOvVaw119CX8yBoCXU3QGEwklu L1

Rahayu, E. (2012, March). Tingkatkan daya saing UKM, APINDO, gandeng microsoft [Increase the competitiveness of SMEs, APINDO cooperates with microsoft]. Retrieved from https://swa.co.id/swa/trends/technology/tingkatkan-daya-saing-ukm-apindo-gandengmicrosoft

Rahayu, S. \& Sumarto, S. (2003). The Practice of industrial relation in Indonesia (Working Paper). Jakarta, Indonesia: SMERU. Retrieved from http://www.smeru.or.id/en/content/practiceindustrial-relations-indonesia

Redfern, W. (2010). Sukarno's guided democracy and the takeovers of foreign companies in Indonesia in the 1960 (Doctoral Dissertation, the University of Michigan). Retrieved from https://deepblue.lib.umich.edu/bitstream/handle/2027.42/77846/wredfern_1.pdf?sequence=1

Robison, R. (2009). Indonesia: The rise of capital (First Equinox edition). Singapore, Singapore: Equinox Publishing.

Robison, R. \& Hadiz. V. (2004). Reorganizing power in Indonesia: The politics of oligarchy in an age of markets. New York, NY: Routledge Curzon.

Roosa, J. (2006). Pretext for mass murder (ebook). Madison, WI: Wisconsin University Press. Retrieved from https://wanibesak.files.wordpress.com/2011/07/pretext-for-mass-murder-byjohn-roosa.pdf. 
Ross, R., \& Trachte, K. (1990). Global capitalism: The new leviathan. New York, NY: State University of New York.

Rosser, A. (2007). Escaping the resource curse: The case of Indonesia, Journal of Contemporary Asia, 37(1), 38-58. doi:10.1080/00472330601104557.

Rupidara, N., \& McGraw, P. (2009). Actors, institutional change and stability in Indonesian industrial relations system. Presented at the 15th World Congress of International Industrial Relations Association, Sydney, Australia. Retrieved from https://www.researchgate.net/publication/260748389_ACTORS_INSTITUTIONAL_CHANG E_AND_STABILITY_IN_THE_INDONESIAN_INDUSTRIAL_RELATIONS_SYSTEM.

Ryan, G., \& Bernard, H. (n.d.). Techniques to identify themes in qualitative data. Retrieved from http://www.analytictech.com/mb870/readings/ryanbernard_techniques_to_identify_themes_in .htm.

Sari, B. (2000). Wage determination model: theory and evidence. Retrieved from https://tuir.tdl.org/ttu-ir/bitstream/handle/2346/18027/31295016612060.pdf?sequence=1.

Schulten, T. (2014,). A Study: Minimum wage regimes in Europe:.... and what Germany can learn from them. Bonn, Germany: Friedrich Ebert Stiftung (FES). Retrieved from http://csdle.lex.unict.it/Archive/LW/Data\%20reports\%20and\%20studies/Others\%20reports \%20and\%20studies/20150121-043330_10558pdf.

Sckopol, T., \& Amenta, E. (1986). States and social policies. Annual Review of Sociology, 12, 131157. Retrieved from http://www.jstor.org.helicon.vuw.ac.nz/stable/2083198

Seekings, J. (2016). Trade Unions and the redesign of South Africa's minimum wage-setting institution in the 1990s (Working paper). Retrieved from https://open.uct.ac.za/bitstream/item/24241/Seekings_Working\%20Paper\%20374_2016.pdf? sequence $=1$ 
Sherr-rinn. (2013, August 16). Kemunduran gerakan buruh setelah 2012 [The decline of trade union movement after 2012]. Koran pembebasan. Retrieved from http://koranpembebasan.org/2015/06/kemunduran-gerakan-buruh-setelah-2012/.

Simpson, B. (Ed.) (2017, October 17). Newly declassified U.S. embassy Jakarta files detail army killings, U.S. support for quashing leftist labor movement. National Security Archive. Retrieved from https://nsarchive.gwu.edu/briefing-book/indonesia/2017-10-17/indonesiamass-murder-1965-us-embassy-files.

Siswanto. (2016, May 1). Ini rintangan judicial review PP pengupahan di Mahkamah Agung [These are the obstacles of the judicial review of the government regulation on the wages in Supreme Court]. Suara. https://www.suara.com/news/2016/05/01/190313/ini-rintangan-judicialreview-pp-pengupahan-di-mk.

Sohuturon, M. (2016, September 29). Buruh pertanyakan nasib uji materi PP pengupahan (The workers called for the progress of Judicial Review of the Government Regulation). CNN Indonesia. Retrieved from https://www.cnnindonesia.com/nasional/20160929173953-20162193/buruh-pertanyakan-nasib-uji-materi-pp-pengupahan.

Stryker, S. (1997). The Rationalization of the political field: Beyond the state and society centered theories of policy change. Barkeley, CA: University of Berkeley. Retrieved from http://www.irle.berkeley.edu/culture/papers/Stryker.pdf.

Sutley, S. (1988). Losing a revolution: The PKI versus the army in Indonesia, 1949-1965. (Thesis. Master of Art. McGill University, Montreal, Canada). Retrieved from http://digitool.library.mcgill.ca/webclient/StreamGatefolder_id=0\&dvs=1523444484283 607

Raditya, I. (2017, March). 2 Maret 1957: Permesta, pemberontakan atau bukan (March 2, 1957: Universe's struggle: Rebellion or not). Tirto. https://tirto.id/permesta-pemberontakan-ataubukan-cjZz 
Taussig, F.W. (1910,). Outlines of a theory of wages. American Economic Association Quarterly, 11(1). Retrieved from http://www.jstor.org/stable/3000026

Tedjasukmana, I. (1959). The political character of the Indonesian trade union movements (Monograph Series). Modern Indonesian Project. Ithaca, NY: University of Ithaca.

Tjandra, S. (2016). Labour law and development in Indonesia (Doctoral Dissertation, Leiden University). Retrieved from https://openaccess.leidenuniv.nl/bitstream/handle/1887/37576/references.pdf?sequence=16

Tjandraningsih, I. (2012). Catatan akhir tahun perburuhan Indonesia: Strategi baru gerakan buruh Indonesia [End-year note: New strategy for Indonesian trade union movement]. Bandung, Indonesia: Akatiga, Retrieved from http://www.akatiga.org/index.php/publikasi/artikel/item/170-strategi-baru-gerakan-buruhindonesia

Tjandraningsih, I., Herwati, R. \& Suhadmadi. (2010). Diskriminatif dan exploitatif: Praktek kerja kontrak dan outsourcing buruh di sektor industri metal di Indonesia [Discriminative and exploitative: Contract and outsourcing system in Metal Industry in Indonesia]. Jakarta, Indonesia: Akatiga, FSPMI, FES. Retrieved from https://library.fes.de/pdffiles/bueros/indonesien/07846.pdf

Tomiyama, A. (2017, August 18). Southeast Asian workers press for big minimum wage hikes. Nikkei Asia. Retrieved from https://asia.nikkei.com/Politics-Economy/Economy/SoutheastAsian-workers-press-for-big-minimum-wage-hikes

Törnquist, O. (2004). Labour and democracy? Reflections on the Indonesian impasse. Journal of Contemporary Asia, 34(3). Retrieved from http://folk.uio.no/ollet/files/Labour.pdf

Törnquist, O. (2011). Democracy and the left: Experiences from Indonesia. Retrieved from https://pdfs.semanticscholar.org/f665/b0b2842651e0c53f9b3b38c50b163aae0993.pdf 
Toussaint, E. (2014, November 2). The World Bank and the IMF in Indonesia: An emblematic interference. Series: Bretton Woods, the World Bank and the IMF: 70th anniversary (Part 11). Liege, Belgia: Committe for the Abolition of Illegitimate Debt. Retrieved from http://www.cadtm.org/Nouvelle-traduction-La-Banque

Triyana, B. \& Isnaeni H. (2016, August 26). Semaun dan Sneevliet, kisah persahabatan dua orang revolusioner [Semaun and Sneevliet, the story of a friendship of two revolutionaries]. Historia. Retrieved from http://historia.id/persona/semaun-dan-sneevliet-kisah-persahabatandua-orang-revolusioner

United State Government Accountability Organisation (US GAO) (2017). Low wage workers: poverty and use of selected federal social safety net programmes persist among working families. Washington DC, WA: GAO. Retrieved from https://www.gao.gov/products/GAO$17-67$

US workers strike in 'fight for $\$ 15$ ' minimum wage campaign. (2017). Telesur $T V$. Retrieved from https://www.telesurtv.net/english/news/US-Workers-Strike-for-Fight-for-15-Minimum-WageHike-20170904-0017.html

Van Thuy, P. (2014). Guided economy. Beyond political skin: Convergent paths to an independent national economy in Indonesia and Vietnam (Doctoral Dissertation, Leiden Univerity, the Netherlands). Retrieved from univ.nl/bitstream/handle/1887/25770/05.pdf;jsessionid=142C54DF4A87BF9102321BF22E94 B246? sequence $=9$

Varkkey, B., Korde, R., \& Singh, S. (2016). Minimum wage comparison: ASIAN countriesminimum wage Fixing. Amsterdam, the Netherlands: Wage Indicator Foundation. Retrieved from https://wageindicator.org/documents/publicationslist/publications-2016/varkkey-bkorde-r-singh-s-2016-minimum-wage-comparison-asian-countries

Vickers, A. (2005). A history of modern Indonesia. Cambridge, England: Cambridge University Press. 
Wages (n.d.). Merriam-Webster dictionary. Retrieved from https://www.merriamwebster.com/dictionary/wage

Wage Theory (2007). In encyclopedia britannica. Retrieved from https://www.britannica.com/topic/wage-theory

Wage and Salary.(2018). In Encyclopcedia Britannica. Retrieved from https://academic-ebcom.helicon.vuw.ac.nz/levels/collegiate/article/wage-and-salary/106209

Wallerstain, I (1984). The politics of the world-economy: The states, the movements, and the civilizations. Cambridge, England: the University Press.

Wallerstain, I. (2007). World-system analysis: An introduction ( $5^{\text {th }}$ ed.). London, England: The Duke University Press.

What are the minimum wages in Indonesia in 2018. (2017, November 9). Indonesia investments. Retrieved from https://www.indonesia-investments.com/news/todays-headlines/what-are-theminimum-wages-in-indonesia-in-2018/item8347?.

World Bank (n.d.) Top 8 countries voting power: based on IBRD subscription and voting power of member countries. Washington DC, WA: World Bank. Retrieved from https://finances.worldbank.org/Shareholder-Equity/Top-8-countries-voting-power/udm3vzz9/data.

World Bank. (2017.) Five myths about the CGI. Jakarta, Indonesia: World Bank. Retrieved from http://siteresources.worldbank.org/INTINDONESIA/Resources/CGI03/00-CGI-Oct17-1800/CGI5Myths.pdf.

Yovanda, Y. (2016, February 15). Pungut iuran miliaran rupiah dari buruh, ini gaji ketua KSPSI. [Collected billion rupiah membership fee from workers, this is the chief of KSPSI' salary]. Sindo News. Retrieved fromhttps://ekbis.sindonews.com/read/1085420/34/pungut-iuranmiliaran-rupiah-dari-buruh-ini-gaji-ketua-kspi-1455525591. 